\title{
Review
}

\section{The Renaissance of Cyclin Dependent Kinase Inhibitors}

\author{
Tobias Ettl ${ }^{1, *}$, Daniela Schulz ${ }^{1,2}$ and Richard Josef Bauer ${ }^{1,2, *}$ \\ 1 Department of Oral and Maxillofacial Surgery, University Hospital Regensburg, 93053 Regensburg, Germany; \\ daniela.schulz@ukr.de \\ 2 Center for Medical Biotechnology, Department of Oral and Maxillofacial Surgery, \\ University Hospital Regensburg, 93053 Regensburg, Germany \\ * Correspondence: tobias.ettl@ukr.de (T.E.); richard.bauer@ukr.de (R.J.B.)
}

check for

updates

Citation: Ettl, T.; Schulz, D.; Bauer,

R.J. The Renaissance of Cyclin

Dependent Kinase Inhibitors. Cancers

2022, 14, 293. https://doi.org/

10.3390/cancers 14020293

Academic Editor: David Wong

Received: 19 November 2021

Accepted: 4 January 2022

Published: 7 January 2022

Publisher's Note: MDPI stays neutral with regard to jurisdictional claims in published maps and institutional affiliations.

Copyright: (C) 2022 by the authors. Licensee MDPI, Basel, Switzerland. This article is an open access article distributed under the terms and conditions of the Creative Commons Attribution (CC BY) license (https:// creativecommons.org/licenses/by/ $4.0 /)$.
Simple Summary: This review provides an overview of the state of knowledge and general understanding of CDK inhibitors currently under development or clinically approved, with a particular focus on the treatment of head and neck cancer. Especially in combination therapy, cyclin-dependent kinase inhibitors exhibit a synergistic effect by attenuating chemo-, radio-, or immune-resistance in some tumor entities, thus improving the success of cancer therapy.

\begin{abstract}
Cyclin-dependent kinases (CDK) regulate cell cycle progression. During tumor development, altered expression and availability of CDKs strongly contribute to impaired cell proliferation, a hallmark of cancer. In recent years, targeted inhibition of CDKs has shown considerable therapeutic benefit in a variety of tumor entities. Their success is reflected in clinical approvals of specific CDK4/ 6 inhibitors for breast cancer. This review provides a detailed insight into the molecular mechanisms of CDKs as well as a general overview of CDK inhibition. It also summarizes the latest research approaches and current advances in the treatment of head and neck cancer with CDK inhibitors. Instead of monotherapies, combination therapies with CDK inhibitors may especially provide promising results in tumor therapy. Indeed, recent studies have shown a synergistic effect of CDK inhibition together with chemo- and radio- and immunotherapy in cancer treatment to overcome tumor evasion, which may lead to a renaissance of CDK inhibitors.
\end{abstract}

Keywords: PD-L1; HNSCC; CDK; CDKI; cell cycle inhibition/blockade; palbociclib; flavopiridol; ribociclib; seliciclib; abemaciclib; trilaciclib; CDK4/CDK6; chemosensitization; radiosensitization; immunosensitization; synergy

\section{Introduction}

One fundamental aspect of cancer is uncontrolled cell growth. When a cancer increases in size, this process reflects an increase in the number of cells due to the process of cell division. This feature is such an important characteristic of cancer cells that a sustained cell proliferation was nominated as one of the six original hallmarks of cancer by Hanahan and Weinberg in 2000 [1].

In order to inhibit tumor proliferation, understanding the mechanisms that control the division process of cancer cells is required. The generation of identical daughter cells is a highly regulated process in healthy cells. However, alterations that may occur in malignant cells can finally lead to uncontrolled cell proliferation. For a better understanding of the mode of action of cyclin dependent kinase inhibitors (CDKIs), we first describe the cell cycle in general and how cyclins and cyclin-dependent kinases (CDKs) play an important role during cell cycle progression. There are studies designed to stop the cell division process in cancer and therefore CDKIs have been developed. However, the complexity of cellular regulation mechanisms makes specific inhibition of proliferation in tumor cells very challenging. In this review we present the progress that has been made in the development of CDKIs so far, as well as the challenges and limitations of CDKI treatment that come 
along in cancer therapy. Despite the many disappointing drawbacks in the history of CDKI development that we will discuss in detail, hormone receptor positive metastatic breast cancer is one of the tumor entities for which there are already clinically approved CDKIs by the FDA that are an integral part of cancer treatment [2].

With CDK inhibition, there are some challenging aspects to deal with. In the context of CDK inhibition was the lack of inhibitor specificity. Furthermore, inhibition of CDKs may not alter just a single but a variety of processes in the cell. Depending on the tumor entity, specific mutations, as well as the differentiation status, tumor cells do not always respond identically and predictable to CDK inhibition. After all, inhibition of CDKs may not only affect tumor cells, but also other cell types like fibroblasts and immune cells. Finally, also questions arise regarding proper dosing and the balance of efficacy and adverse outcomes, which may vary depending on the CDK inhibitor type.

As we discuss in this review, interestingly, CDKIs have not necessarily performed as well as monotherapy. Instead, CKDIs have been shown to be particularly effective in combination with chemo-, radio-, or immunotherapy. Such promising combination therapy strategies are of great interest for tumor entities such as head and neck cancer (HNSCC), upon which we will particularly focus in this review. In HNSCC, for instance, the 5-year overall survival rate has hardly improved for decades, despite all medical progress in the last years [3]. The combination of CDKIs with the simultaneous inhibition of mutated signaling pathways used by tumor cells as an evasion mechanism as well as the simultaneous stimulation of the immune system seem to be promising strategies for future tumor therapies which, in our opinion, could lead to a renaissance of CDKIs.

\section{Cyclin-Dependent Kinases}

It was only about two decades ago that the key concepts of CDK biology were discovered by studying yeast and the synchronous cycles of division in embryo extracts. Not much later Leland H. Hartwell, R. Timothy Hunt and Paul M. Nurse were awarded the Nobel Prize for their achievements [4]. Over time, further studies revealed the distinct functions of CDKs. The evolutionary expansion of the CDK family in mammals led to the classification of CDKs into three cell-cycle-related (CDK1, CDK4 and CDK5) and five transcriptional subfamilies (CDK7, CDK8, CDK9, CDK11 and CDK20). However, there are many other important $\mathrm{CDKs}$ that transmit and respond to a wide variety of growth regulatory signals and therefore influencing cell proliferation. For example, CDK4 and CDK6 ensure smooth entry into the cell cycle. CDK1 was found to be a key factor in mitosis and CDK2 to be essential in the replication of DNA in higher eukaryotes. CDK7, CDK8/19, CDK9, CDK12/13 were identified to play important roles during the regulation of RNA transcription [5-7].

Considering the tremendous role of CDKs during cell division, it is not surprising that tumor cells have developed a number of strategies to disable or bypass these key components [8]. In the last 20 years, researchers have developed numerous drugs to manipulate the activity of CDKs to inhibit uncontrolled tumor proliferation. Many of these drugs have already been used as cancer treatment, but with varying degrees of success. In the past, monotherapy with CDKIs showed rather often disappointing results. Recently, however, CDKIs have been used more effectively in therapy, especially when used as combination therapy with chemo- and radiotherapy. Combination therapy with CDKI has also achieved initial success in the context of immunotherapy, which will be discussed in more detail later in this review. Their success may now lead to a veritable renaissance of CDKIs.

\subsection{Role and Function of CDKs}

Cell division is essential for the development and maintenance of a healthy organism. Cell cycle progression is a highly regulated process. The cell cycle consists of several distinct phases. In G0, the quiescent state, the cell enters right after a successful cell division and remains before it probably enters a proliferative state. When the cell switches to 
a proliferative state, the cell enters G1 and the synthesis phase (S phase), where DNA synthesis occurs, followed by $\mathrm{G} 2$ and mitosis phase (M phase), in which the cell divides into two identical daughter cells. Cell cycle checkpoints ensure that processes are carefully executed and that proper duplication of DNA and other cell contents has occurred before the cell enters the next phase. Any mitotic cell division requires correct DNA replication to take place in $\mathrm{S}$ phase. During mitosis, the machinery required for chromosome division is present, leading to the formation of daughter cells. Here, CDKs exert an enormous functional influence and perform distinct functions during distinct phases of the cell cycle. Ranging from the initiation of DNA replication sites along the chromosomes before $S$ phase, they phosphorylate histone proteins during $S$ and $M$ phases, resulting in chromatin conformation. Besides that, they regulate the degradation of the nuclear membrane by phosphorylation of nuclear proteins, such as lamins or nucleoporins, at the beginning of $\mathrm{M}$ phase and engage in phosphorylation of centrosome-associated proteins in preparation for mitosis.

Each phase transition in the cell cycle is regulated by a specific subset of cyclins and CDKs. CDKs are involved as key regulatory enzymes that sensitively control all cell cycle transitions through restriction points (R-points) [9]. Among the serine/threonine (Ser/Thr) kinases, CDKs represent a distinct subfamily of enzymes. Together with cyclins, CDKs are the core components of the molecular machinery that determines whether a cell continues to progress through the cell cycle or enters a stage where cell growth is arrested.

In addition, there is a whole series of CDKs known to keep the transcriptional machinery running. These transcriptional CDKs (tCDKs) control the activity of RNA polymerase from binding to the promoter to recycling of the polymerase. This process, called the transcription cycle, integrates multiple sources of information to ensure that RNA synthesis at all genomic is precisely adapted to the requirements of the cell.

\subsection{Regulation of Cell Cycle CDKs}

To ensure an uninterrupted cell cycle progression, CDKs are continuously monitored. The activity of CDKs is regulated by phosphorylation and dephosphorylation of the catalytic subunit as well as by the interaction with cyclins. CDKs and cyclins form functional complexes in which cyclins activate the catalytic activity of cell phase specific CDK interaction partners. This in turn triggers phosphorylation signals of a variety of responder molecules at their Ser/Thr residues and thereby directs cells through the cell cycle.

More specifically, when cells from G0 enter the cycle, CDK4 and CDK6 form active complexes with D-type cyclins (D1, D2, D3) and, among other proteins, phosphorylate the retinoblastoma protein $(\mathrm{pRb})[10]$. $\mathrm{Rb}$ is one of the foremost investigated tumor suppressor protein substrates of CDK which prevents cells from entering cell cycle under normal conditions. Phosphorylation of Rb by CDKs causes its inactivation and allows cells to enter a new cell cycle. In its phosphorylated form, the binding of RB1 to E2F transcription factors is released, which is necessary for cell cycle progression. In a non- or low-phosphorylated condition, $\mathrm{pRb}$ forms repressor complexes by binding to E2F transcription factors. Further, the CDK2/cyclin E complex phosphorylates Rb family members and inactivates them [11]. The subsequent release of transcription factors allows the cells to pass the R-point and move from $G 1$ to the $S$ phase $[10,12]$ (Figure 1).

During $\mathrm{S}$ phase progression, CDK2 exchanges its E-cyclin partners and replaces them with cyclins A1 and A2. These cyclins in turn then switch from CDK2 to CDK1 (CDC2) in late S phase. Once the cell enters G2 phase, CDK1 binds to cyclins B1 and B2. Finally, this CDK1/cyclin B1/B2 interaction drives the passage through $\mathrm{M}$ phase by controlling many events from prophase to telophase [9]. Once the $\mathrm{M}$ phase is complete, the B-cyclin level drops again to almost zero. The level then rises again over the course of the entire cell cycle, in preparation for the next cell division. All other cyclins undergo similar cycles and induce the distinct phases of cell division (Figure 2). 


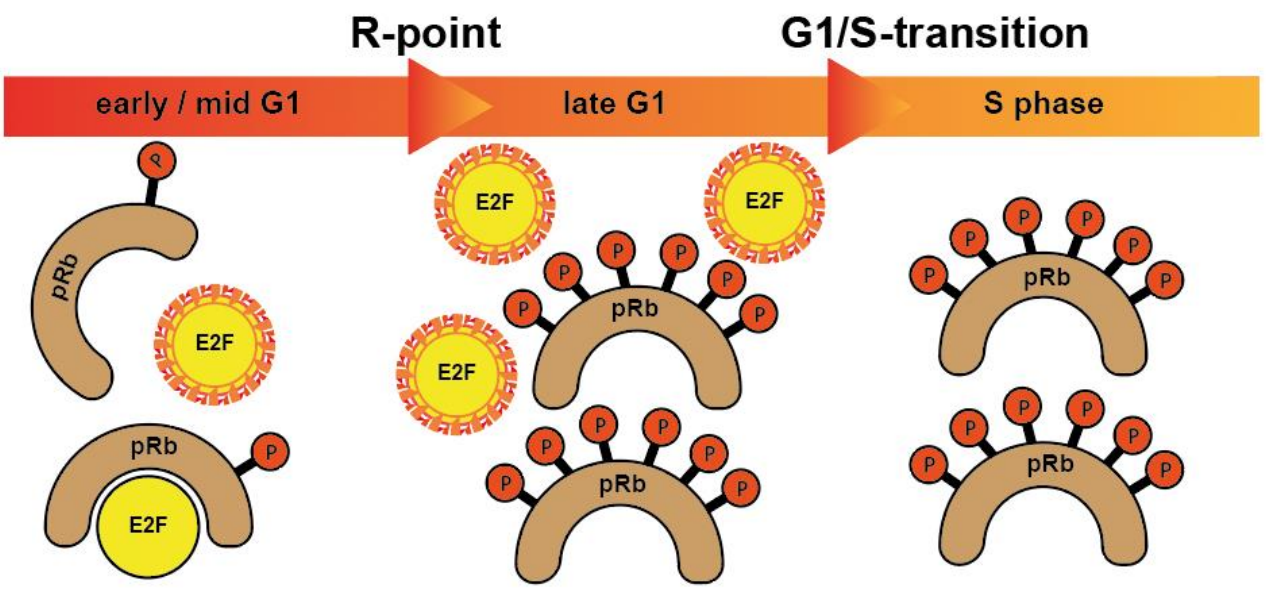

Figure 1. $\mathrm{pRb}$ proteins bind to and block E2F transcription factors, controlling the expression of E2F responsive genes in specific cell cycle phases. After being hyperphosphorylated at the restriction point (R-point), pRb proteins release E2F transcription factors allowing them to activate the transcription of numerous genes crucial for cell cycle progression. When cells enter S phase, E2Fs are degraded. Hence, E2Fs are active only from late G1 until entry into S phase.

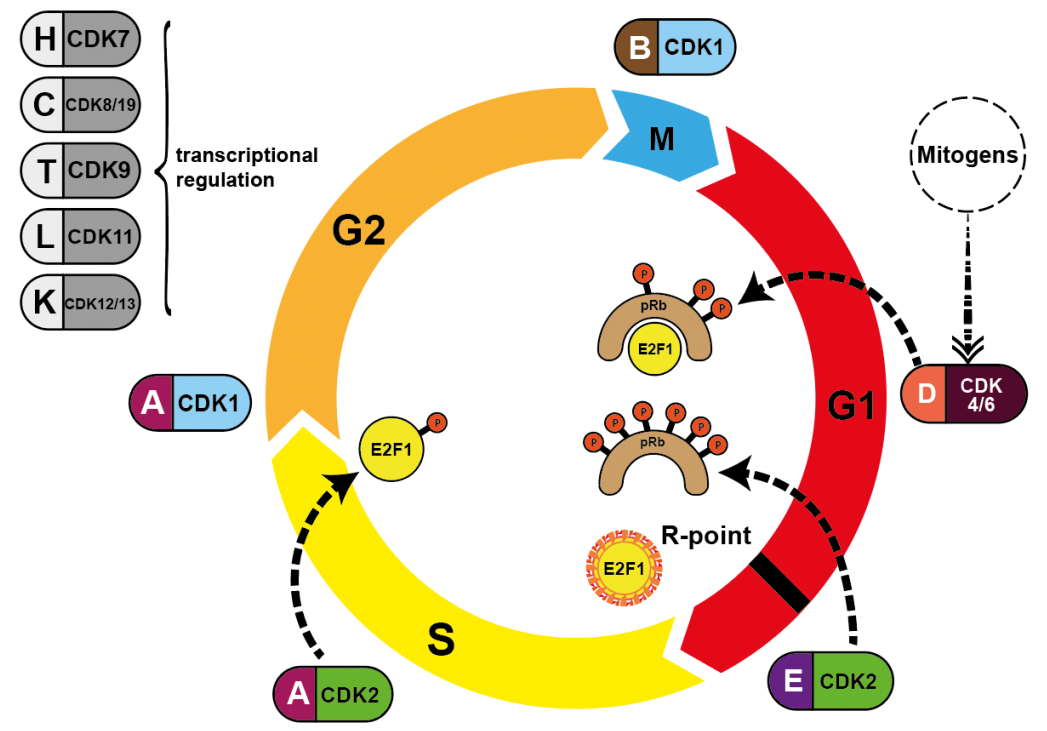

Figure 2. Pairing of cyclins with the respective CDK during cell cycle progression. Mitogenic stimulation leads to the synthesis of D-type cyclins via mitogenic pathways, activating CDK4/CDK6/cyclin $\mathrm{D}$ and ultimately CDK2/cyclin E. CDK4/CDK6 phosphorylate Rb proteins (dotted lines) and CDK2 further phosphorylates $\mathrm{Rb}$ subsequently reversing suppression of transcription factor E2F1. This allows DNA synthesis to occur. S phase is terminated when CDK2/cyclin A phosphorylates E2F1, blocking its DNA-binding ability. CDK7, CDK8/CDK19, CDK9 CDK11 and CDK12/CDK13 are all involved in transcriptional initiation and DNA elongation processes.

\subsection{Regulation of Transcriptional CDKs}

In addition to the CDKs that regulate the cell cycle, a whole series of CDKs are known to keep the transcriptional machinery running. These transcriptional CDKs (tCDKs) control the activity of RNA polymerase from binding to the promoter to recycling of the polymerase (Figure 3). During the progression of RNA transcription, multiple CDK-cyclin complexes act sequentially to promote transitions between and progression through the different stages of transcription: first the initiation of RNA transcription, second the elongation of RNA and third the termination of RNA Polymerase II (RNA Pol II). Unphosphorylated RNA Pol II is able to re-enter the cycle, which is called RNA Pol II recycling. 
This process, called the transcription cycle, integrates multiple sources of information to ensure that RNA synthesis at all genomic loci is precisely tailored to the cell's requirements. Our understanding of the transcription cycle is still limited. More recently, attempts have been made to manipulate transcriptional activity for cancer control through inhibition of tCDKs, both in basic and applied sciences. Targeting tCDKs may provide a sufficient therapeutic window to be effective in the clinic [13].

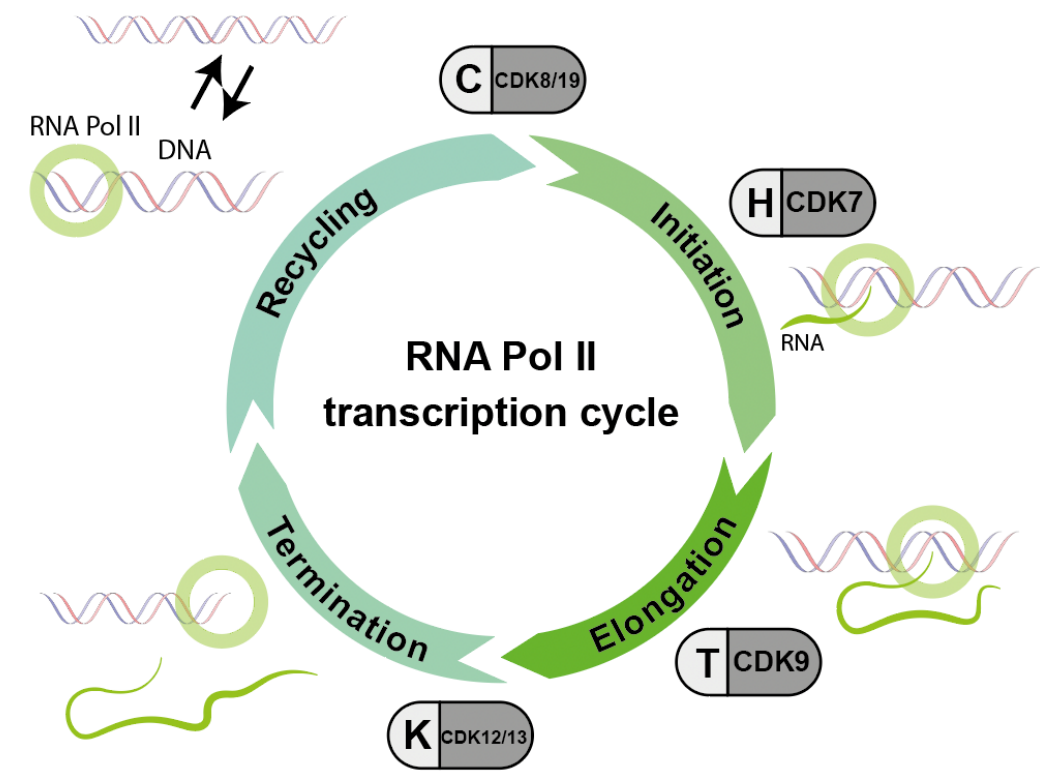

Figure 3. Basic scheme of the sequential action of different cyclin/CDK complexes which are important for the phosphorylation cycle and consequently the activity of RNA polymerase II (RNA Pol II). Accordingly, inhibitors against these CDKs interfere with the RNA transcription process (modified according to Parua et al. [14]).

\subsection{Cell Intrinsic CDK Inhibition}

For cancer treatment, the goal is to specifically interrupt cell cycle progression to stop tumor growth. For this purpose, CDK inhibitors have been developed. However, the cell cycle is of course also regulated naturally. The action of CDKs is controlled by specific activation and inactivation by other proteins, cell intrinsic CDK inhibition. Typically, cyclin/CDK complexes are activated by phosphorylation of the CDK-activating kinase (CAK). On the contrary, these complexes can be negatively regulated by a number of cell intrinsic CDKIs [12]. In healthy cells, this mechanism prevents uncontrolled proliferation. In cancer cells, however, these mechanisms are disturbed. Cyclin D1, for instance, is susceptible to extrinsic mitogenic stimulation, providing a link between the external environment and the intrinsic cell cycle machinery.

Based on their structural and functional properties, naturally occurring CDKIs belong to two large families, INK4 and Cip/Kip, which are displayed in Figure 4 . The cell intrinsic CDK inhibition mechanism involves interaction between the p16- and CDK6charged binding domains, resulting in reduced kinase activity and a decreased cyclinbinding surface.

The INK4 family includes the CDKIs p15, p16, p18 and p19 and consists of tandem repeats of an ankyrin-like sequence [15-18]. The INK4 family members inhibit the D-type cyclin activity through selective interaction with CDK4 and CDK6. The CDK interacting protein/Kinase inhibitory protein (Cip/Kip) family includes the CDKIs p21, p27 and p57 and is characterized by a homologous amino-terminal domain that contains contiguous cyclin- and CDK-binding regions [19-21]. Amongst others, the Cip/Kip family members inhibit the activity of CDK2 by binding both to cyclin E/CDK2 and to cyclin A/CDK2 complexes. Cip/Kip family members can also target CDK4/6 and might work either as activators or inhibitors [22,23]. P27 was first identified as cell intrinsic CDKI. P27 is known 
for its ability to block the activity of cyclin E/CDK2 and cyclin A/CDK2 in cells arrested in G1, by TGF- $\$$, lovastatin or contact inhibition [20,21] (Figure 4).

\section{Cell intrinsic CDK inhibitors}
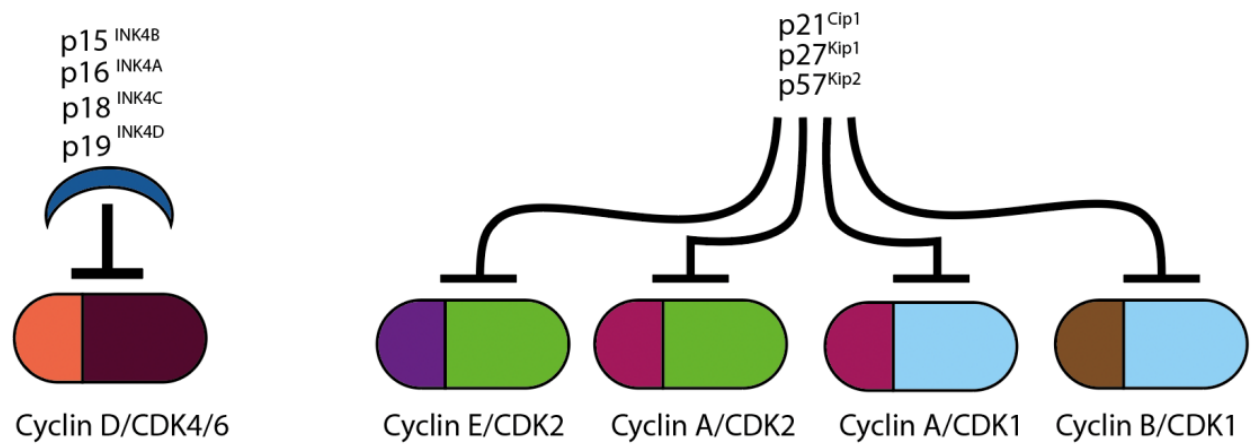

Figure 4. Cell intrinsic CDKCDKIs block the actions of CDKs at various time points of the cell cycle. The four illustrated INK proteins specifically inhibit cyclin D/CDK4/CDK6 complexes which are active in the G1 phase of the cell cycle. The three illustrated Cip/Kip proteins inhibit the remaining cyclin/CDK complexes which are active throughout the whole cell cycle.

There are also numerous data in literature showing a reduction on tumor progression by cell intrinsic CDK inhibition. P16, p53, p21 and p27 proteins represent endogenous CDKIs. It was shown that induction of these inhibitors caused arrest of the cells in G1/S phase, or directly forced cells into apoptosis in various tumor cells, such as breast, prostate and lung cancer [24-30].

\subsection{Dysregulation of Catalytic Components of CDKs}

Dysregulation of the cell cycle may lead to the manifestation of various clinical conditions, and in the worst case, to cancer. Here, especially the dysregulation of the catalytic components of CDKs can lead to the disruption of regular cell cycle progression [8,9].

For example, mutations of CDK4 and CDK6, which have been found in melanoma and other tumor types, can disrupt the regular progression of the cell cycle [17]. Additionally, overexpression of the regulatory subunit of cyclins is common cause of dysregulation in malignancies. Amplification of cyclin D, cyclin E and cyclin B1 has been reported in leukemia, lymphoma and various solid tumors as a result of gene amplification, rearrangement or translocation $[11,12,17]$. CDK2 is shown to be dysfunctional in several malignancies, including lung cancer (cyclin A/CDK), melanoma, osteosarcoma and ovarian cancer (cyclin E/CDK2), which is usually due to overexpression of cyclin E and/or cyclin A [9].

To prevent uncontrolled progression of the cell cycle, resulting in uncontrolled proliferation and the accumulation of mutations in malignant cells, many studies have aimed to develop specific and selective CDKIs as a potential therapeutic approach to target cancer. However, due to the complex mechanisms by which the cell cycle is regulated, there have been many challenges in finding a successful tumor therapy. In the next paragraph we will discuss the possibilities of CDK inhibition and the different types of CDKIs.

\section{Pharmacological Compounds for CDK Inhibition}

In past decades, many efforts have been made to develop kinase inhibitors capable of modulating cyclin-CDK complexes, either by mimicking the function of natural CDK inhibitors such as p21, p16, and p27 or by directly modulating cyclin-CDK complexes or their targets. Retinoblastoma protein is one of the foremost investigated tumor suppressor protein substrates of CDK which prevents cells from entering cell cycle under normal conditions. Phosphorylation of $\mathrm{Rb}$ by CDKs causes its inactivation and allows cells to enter a new cell cycle. Many cancers are associated with hyperactivation of CDKs due to mutation of CDK genes or cell intrinsic CDK inhibitor genes. Therefore, CDK modulators 
are of great interest as novel therapeutics against cancer and have led to the discovery of several CDK inhibitors in the clinic.

There is still no consensus on whether peptides or small molecules are more suitable for therapeutic applications. Peptides are more selective because they are derived from linear protein sequences. Peptides should mimic the catalytic or regulatory subunits of cell cycle control complexes, but on the other hand they usually have poorer pharmacokinetic properties. In contrast, small molecules have better pharmacokinetic properties but lower specificity. The reason is that many protein kinases have high sequence similarity in the active site.

\subsection{Small Molecules}

Growing knowledge about protein sequences, structures and interacting partners has made it possible to optimize peptides in terms of molecular design. Due to their high target specificity, peptides offer a promising opportunity for CDK inhibition.

The first therapeutic approaches were made with pharmacologically active peptides designed to mimic the catalytic or regulatory subunits of cell cycle control complexes. For instance, peptides based on p21 were designed to block the cyclin E/CDK2 complex. To be delivered into cells, these peptides were fused with the cargo peptide penetratin, a cell penetrating peptide (CPP) derived from the Drosophila Antennapedia protein (Antp) [31]. Depending on which region of the protein the peptides originated, the inhibition was more or less effective [32]. Some well-known small molecules are flavopiridol, roscovitine, SNS-032, R-547, AT-7519, PD-0332991, UCN-01, indirubin derivatives, dole-3 carbinol, paullones, and hymenialdisine [33]. Several of them will be described in more detail in their function and mode of action later in the text.

However, small molecules have low specificity, as many protein kinases have high sequence similarity in the active site. This would explain why small peptides cannot achieve desired treatment results. The pharmacokinetic properties of these molecules are often very poor in vivo, meaning the large and highly charged peptides are unstable and rapidly degraded and do not reach the necessary concentration at the actual tumor site [34].

\subsection{Stapled Peptides}

In parallel to the classical inhibition attempts, stapled peptides were used to inhibit the interaction between CDK4 and its binding partner cyclin D1, recently. Stapled peptides are short peptides, typically arranged in an alpha-helical conformation, which is constrained by a synthetic brace, a so-called staple (Figure 5). This conformation allows an increase target affinity, increased cell penetration and protection against proteolytic degradation [35].

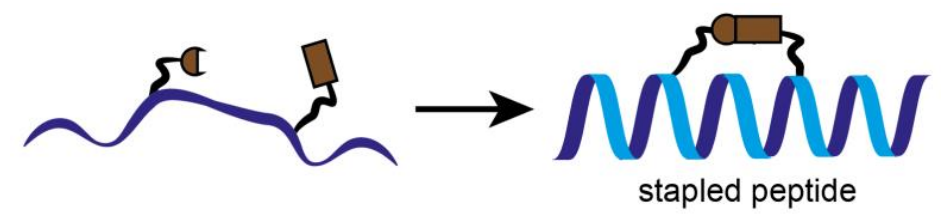

Figure 5. Schematic representation of stapled peptides. To keep the peptide into a more stable alpha helical form and optimize its properties, individual amino acids are crosslinked together. Stapled peptides can enter cells, bind to therapeutic targets and modulate biological structures and properties, and may be of great interest as inhibitors of protein-protein interactions (PPI).

Stapled peptides derived from the $\alpha$-helix of CDK4 involved in the primary interaction with cyclin D1, are designed to inhibit cyclin D/CDK4. The peptides are constrained with hydrocarbon staples, modified amino acids ( $\alpha$-methyl, $\alpha$-alkenylglycine) into strategic positions of a peptide sequence which induce an alpha-helical conformation [36]. This structural property stabilizes the peptides and makes them much less prone to degradation by proteases. As a result, their ability to interact with their target and penetrate cell membranes is enhanced [37,38]. They fold into an $\alpha$-helix in solution in the absence of cyclin D1, and interact with cyclin D1 with high affinity compared to the unstapled 
peptides [39]. Stapled peptides target the main interface between CDK4 and cyclin D which is essential for the kinase activity of CDK4.

However, stapled peptides are not very specific since they have been shown to affect the kinase activity of various other CDKs since the amino acids involved in the $\alpha 5$-helix that interacts with the $\mathrm{C}$ helix of CDKs are highly conserved. Although an anti-proliferative effect was observed in various NSCLC cell lines, no inhibition of lung tumors in mice by stapled peptides was observed after intravenous injection. This was probably because the concentration at the tumor site was too low. In orthotopic lung tumors of mice, the peptides were able to successfully inhibit the growth only in combination with abemaciclib [40].

A well-known stapled peptide is the $\alpha$-helical peptide ALRN-6924. It has entered a clinical phase I trial in patients with solid tumors and lymphomas [41]. ALRN-6924 activates p53-dependent transcription at the single-cell and single-molecule levels and exhibits biochemical and molecular on-target activity in leukemia cells in vitro and in vivo. Dual MDMX/MDM2 inhibition by ALRN-6924 inhibits cellular proliferation by inducing cell cycle arrest and apoptosis in cell lines and primary AML patient cells, including leukemic stem cell-enriched populations, and disrupts functional clonogenic and serial replication capacity. Furthermore, ALRN-6924 significantly improves survival in AML xenograft models. Our study provides mechanistic insights that support further testing of ALRN-6924 as a therapeutic approach in AML and other cancers with wild-type p53 [42].In breast cancer, letrozole or fulvestrant are used in addition to stapled peptides. For MM cisplatin, paclitaxel, bortezomib or dexamethasone are applied in combination [43-45].

\subsection{PROTACs and Molecular Glue}

Novel approaches in molecular biology that employ CRISPR technology selectively remove specific proteins from the cell instead of inhibiting protein activity. This technology also has promising potential applications in therapy. In this case, the protein is targeted for degradation via the cell's natural ubiquitin-proteasome pathway (UPS). Compounds such as molecular glues and proteolysis targeting chimeras (PROTACs) initiate this process by binding the target protein to an E3 ligase. Currently, there are many efforts to convert low potency inhibitors to PROTACS. These are small molecules consisting of two active domains and a linker capable of removing specific proteins from the cell (Figure 6.). PROTACs induce selective intracellular proteolysis and consist of two covalently linked molecules capable of binding proteins: One part binds an E3 ubiquitin ligase, and another part binds to the target protein to be degraded. Recruitment of the E3 ligase to the target protein results in ubiquitination and subsequent degradation of the target protein by the proteasome. PROTACs do not inhibit enzymatic activity but bind their target proteins with high selectivity $[46,47]$.

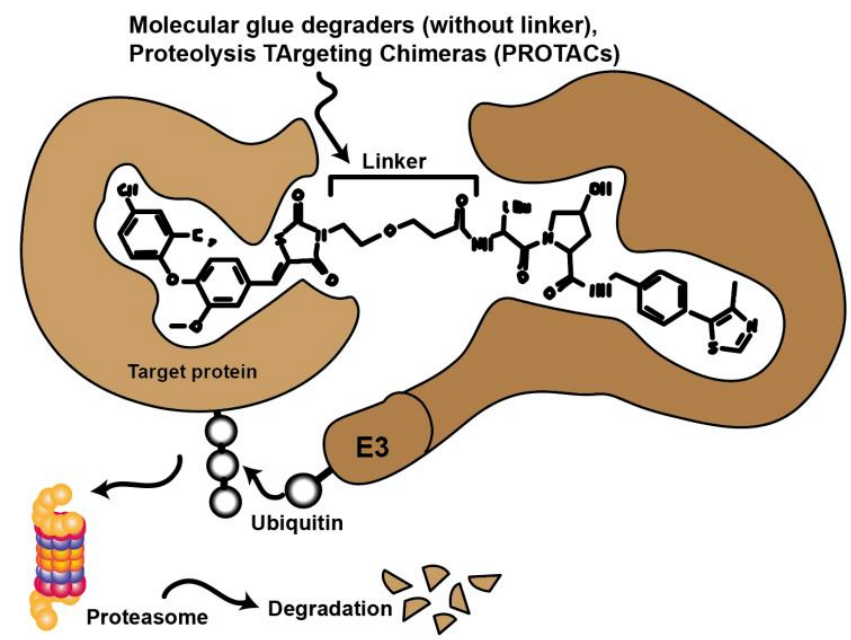

Figure 6. Schematic representation illustrating the mode of action of proteolysis targeting chimeras 
(PROTACs) and molecular glues. Chemical compounds that bind to both target protein and ubiquitinylating E3 ligase to bring these proteins into spatial proximity. The target protein is then tagged and proteasomally degraded.

PROTACs that can inhibit or degrade CDKs are also currently in development. Table 1 lists several PROTACs that have the potential to target and degrade cyclin-dependent kinases with minimal doses.

Table 1. Collection of some CDK degrading PROTACs currently under development.

\begin{tabular}{ccc}
\hline PROTAC & Target & Reference \\
\hline Prodrug 11 & CDK2/4/6 & {$[48]$} \\
Pal-pom & CDK4/6 & {$[49]$} \\
BSJ-03-123 & CDK4/6 & {$[50]$} \\
PROTAC 6 & CDK6 & {$[51]$} \\
CP-10 & CDK6 & {$[52]$} \\
YX-2-107 & CDK6 & {$[53]$} \\
CST651 & CDK6 & {$[54]$} \\
JH-XI-10-02 & CDK8 & {$[55]$} \\
PROTAC 3 & CDK9 & {$[56]$} \\
PROTAC 11c & CDK9 & {$[57]$} \\
B03 & CDK9 & {$[58]$} \\
THAL-SNS-032 & CDK9 & {$[59]$} \\
F3 & CDK9/CDK2 & {$[60]$} \\
\hline
\end{tabular}

\section{Development of Non-Selective Pan-CDK Inhibitors}

Since cell cycle dysregulation may play a key role in tumor development, many different CDKIs have been developed as anti-cancer drugs.

As the following section points out, the early developed CDKIs experienced only moderate clinical success with partly severe side effects. It was later concluded that the main reason for their failure was the functional diversity of individual CDKs. The use of non-specific CDK pan-inhibitors that addressed several CDKs simultaneously triggered uncontrollable effects which could ultimately cause more harm than good in cancer patients.

In the following, the history of CDKI development, with all its successes, problems and limitations, will be discussed in more detail.

\subsection{First Generation of CDK Inhibitors}

First generation of CDKIs were non-specific pan-inhibitors (Figure 7). These agents induce G1 and G2 phase cell cycle arrest, finally leading to apoptosis. Initially, their effect was attributed to the inhibition of the cell cycle CDKs. However, later studies demonstrated that many of the cellular activities of these inhibitors were probably the result of CDK7 or CDK9 inhibition, the CDKs responsible for regulation of RNA transcription in the mitotic phase of cell division, as well as apoptosis-related genes (Figure 2) [61,62].

Flavopiridol, also known as alvocidib (Sanofi-Aventis), is the most extensively investigated CDKI among the first-generation inhibitors. Between 1998 and 2014 more than 60 clinical trials have been conducted. It has been shown to inhibit CDK1, CDK2, CDK4, CDK6, CDK7 and CDK9. In certain contexts it also induces a cytotoxic response, probably as a result of CDK7 and CDK9 inhibition that leads to suppression of RNA transcription [63-66]. Flavopiridol did not meet the high expectations for a CDKI in the clinical context. In contrary to the broad and substantial in vitro activity, there was quite little activity observed in in vivo studies [66]. Flavopiridol has demonstrated some clinical efficacy in hematological malignancies, such as chronic lymphocytic leukemia (CLL), but responses were limited by toxicity [67]. In Phase II studies flavopiridol did not meet necessary criteria although there is evidence that it may have clinical activity in hematological malignancies, such as CLL and mantle cell lymphoma (MCL) $[68,69]$. Scheduling seems to influence flavopiridol's efficacy. Response rates as high as $41 \%$ in 22 assessable patients 
with CLL were mostly associated with short infusion time $(4 \mathrm{~h})$ [67]. Despite these reports and extensive investment, no Phase III studies have emerged and drug development of flavopiridol was consequently discontinued in 2012.

\section{first-generation pan-CDK inhibitors}

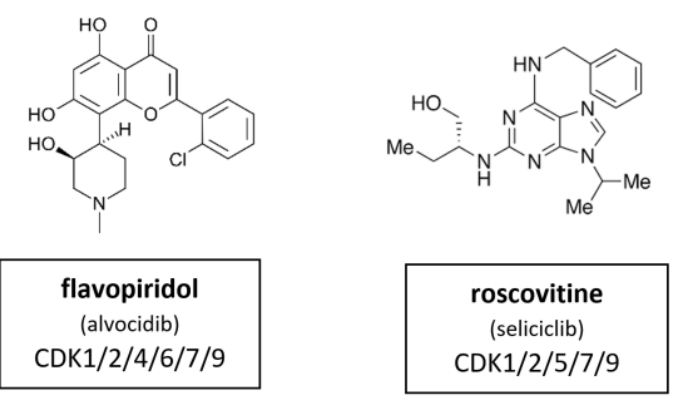

Figure 7. Structure of the first-generation pan-CDK inhibitors flavopiridol (also known as alvocidib) and roscovitine (also known as seliciclib).

In parallel, a purine based CDKI called roscovitine, also known as seliciclib (Cyclacel), was evaluated in a Phase I trial with non-small cell lung cancer (NSCLC) patients. Roscovitine inhibits CDK1, CDK2, CDK5, CDK7 and CDK9. The plasma levels of roscovitine in phase I studies were not sufficiently sustained, as demonstrated in vitro [70]. Accordingly, attempts to measure Rb phosphorylation and cyclin D1 expression did not show reliable alteration of biomarkers under treatment [71]. The response rate was very low. Out of 56 only one single patient with hepatocellular carcinoma (HCC) achieved a partial response [72]. A subsequent blinded randomized phase II study (APPRAISE) with 187 patients was terminated. Its results were never published but the Cyclacel press release stated there was no difference between the seliciclib and placebo arms in terms of progression free survival (PFS) (48 versus 53 days respectively) but an increase in median overall survival was observed, favoring the seliciclib arm over the placebo arm (388 versus 218 days respectively). There was also a phase II, dose ranging, multicenter, randomized, double-blind, placebocontrolled study (ROSCO-CF) with 36 cystic fibrosis patients ( 24 treated, 12 controls). This study was terminated in 2018 [73]. Currently, a multicenter study of roscovitine is ongoing for Cushing's disease (2021).

\subsection{Second Generation of CDK Inhibitors}

The main drawback of the first-generation CDKIs flavopiridol and roscovitine was their lack of selectivity with concomitant adverse effects for patients while not having sufficient efficacy to prevent tumor progression. The focus of further development was therefore on increasing the selectivity of CDKIs.

Out of the next generation CDKIs dinaciclib, also known as MK-7965 or SCH7279656 (Merck, Darmstadt, Germany), has been most extensively studied clinically (Figure 8). Compared to flavopiridol, dinaciclib highly effectively targeted CDK2 and CDK5 (IC 50 values of $1 \mathrm{nM}$ each versus 12 and $14 \mathrm{nM}$ with flavopiridol). IC 50 of CDK1 and CDK9 were equally high between flavopiridol and dinaciclib with $3 \mathrm{nM}$ and $4 \mathrm{nM}$ each in ovarian carcinoma. The suppressive activity against CDK4, CDK6 and CDK7 was less, with $\mathrm{IC}_{50}$ values ranging between $60-100 \mathrm{nM}$. In vitro, dinaciclib completely suppressed $\mathrm{Rb}$ phosphorylation, which correlated with apoptosis onset and total inhibition DNA synthesis in $>100$ tumor cell lines of diverse origin and background. Furthermore, dinaciclib showed improved efficacy against solid tumors in a range of mouse models with doses below the maximally tolerated level [74]. Dinaciclib has shown some activity in MYCN-driven neuroblastoma, attributed to inhibition of CDK2 and CDK9. The overexpression of CDK2 in neuroblastoma tissue is associated with poor overall survival, suggesting a potential strategy for patient selection during clinical development of this drug [75]. 
second-generation pan-CDK inhibitors
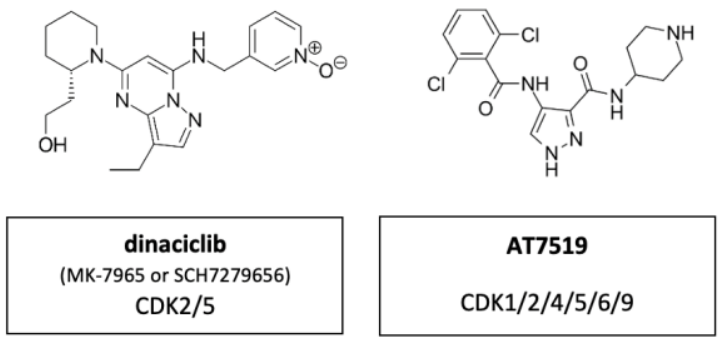

Figure 8. Structure of the second-generation pan-CDK inhibitors dinaciclib (also known as MK-7965 or SCH7279656) and AT7519.

An initial phase I trial on dinaciclib included 48 patients. Ten patients achieved a prolonged stable disease for at least four treatment cycles and it was classified as safe and well tolerated [76]. However, Phase II trials revealed disappointing results.

A randomized Phase II trial with metastasizing breast cancer patients was terminated because the time to disease progression was inferior with dinaciclib treatment compared with capecitabine treatment. Moreover, grade 3 or 4 treatment-related adverse events were common and included neutropenia, leukopenia, increase in aspartate aminotransferase, and febrile neutropenia [77]. Additional randomized Phase II trials with NSCLC patients and patients with advanced acute myeloid leukemia (AML) (patients $\geq 60$ years of age) or acute lymphoblastic leukemia (ALL) concluded that dinaciclib has no activity as monotherapy or did not show any objective responses with dinaciclib [78,79].

In contrast, a Phase II trial with patients with relapsed multiple myeloma (MM) demonstrated encouraging single-agent activities with two patients achieving a deep response and ten patients obtaining some degree of M-protein stabilization or decrease [80]. Furthermore, dinaciclib proved useful in the treatment of specific hematological malignancies.

A Phase III study, which was terminated in 2017, concluded that dinaciclib demonstrated an acceptable and tolerable safety profile compared to ofatumumab, a human B-cell inhibitory monoclonal antibody targeting CD20, in patients with relapsed/refractory CLL. In contrast to first-generation CDKIs, tolerability of dinaciclib, appeared to be greatly improved [81].

More clinical trials on CDKIs include AT7519 (Astex), an inhibitor of CDK1, CDK2, CDK4, CDK5, CDK6 and CDK9. Treatment with AT7519 induces cell cycle arrest in G0/G1and G2/M-phase. The compound has excellent anti-tumor efficacy in human colorectal cancer xenograft models, with extensive tumor regression, impact on pharmacodynamic biomarkers and increased PARP cleavage, indicative of apoptotic cell death [82].

Several Phase I/II trials were conducted in patients with previously treated MM, with relapsed MCL, CLL, advanced or metastatic solid tumors or refractory non-Hodgkin's lymphoma (NHL). None of these studies progressed beyond phase II. Only indirubin entered Phase IV stage. Table 2 lists most of the pan-CDKIs that have entered a clinical trial (2021). Some of the listed compounds like AG024322 were not proven to be clinically efficacious [83].

Indirubins are bisindole alkaloids that naturally occur in indigo-containing plants such as Indigofera tinctoria $\mathrm{L}$. and Isatis tinctoria $\mathrm{L}$. as well as in mollusks of the family Muricidae. They belong to the rather small family of indigoids, which, however, has become very important in the medical field. Indirubin has been found to be the active ingredient of a traditional Chinese medicine. In the 1980s, indirubins were clinically tested for the treatment of chronic myeloid leukemia (CML). More than 50\% of CML patients experienced partial or complete remission [84], similar to standard treatment with the cytostatic drug busulfan [85]. Furthermore, indirubin toxicity was low and side effects, which occurred in about half of the participants. These encouraging results encouraged researchers to investigate the use of indirubin and its novel derivatives in other cancers and diseases. 
Table 2. Pan-CDK inhibitors evaluated in clinical phase trials.

\begin{tabular}{|c|c|c|c|c|c|}
\hline Drug & Synonym & $\mathrm{IC}_{50}$ & Target & Progress & Application \\
\hline Flavopiridol & $\begin{array}{l}\text { Alvocidib, L868275, } \\
\text { HMR-1275 }\end{array}$ & 20-100 nM & CDK1,2,4,6,7,9 & $\begin{array}{c}\text { Phase II } \\
\text { NCT03604783 }\end{array}$ & $\begin{array}{c}\text { ALL, AML, CLL, MM, } \\
\text { lymphoma, MCL } \\
\text { NSCLC, Crohn's disease, Niemann }\end{array}$ \\
\hline Roscovitine & CYC202, Seliciclib & $0.16-0.7 \mu \mathrm{M}$ & CDK1 $1,2,5,7,9$ & $\begin{array}{c}\text { Phase II } \\
\text { NCT03774446 }\end{array}$ & $\begin{array}{c}\text { Pick Disease Type C, metastatic } \\
\text { breast cancer, } \\
\text { advanced solid tumor }\end{array}$ \\
\hline Dinaciclib & SCH 727965, SCH-727965 & $1-4 \mathrm{nM}$ & CDK1,2,5,9 & $\begin{array}{c}\text { Phase III } \\
\text { NCT01580228 }\end{array}$ & $\begin{array}{c}\text { CLL, MCL, NSCLC, } \\
\text { melanoma, breast cancer }\end{array}$ \\
\hline P276-00 & Riviciclib hydrochloride, P276 & $20-79 \mathrm{nM}$ & CDK1,4,9 & $\begin{array}{c}\text { Phase II } \\
\text { NCT00899054 }\end{array}$ & BC, HNSCC \\
\hline TG02 & SB1317, TG-02, SB-1317 & n.a. & CDK1,2,5,7,9 & $\begin{array}{c}\text { Phase II } \\
\text { NCT03904628 }\end{array}$ & $\begin{array}{c}\text { glioblastoma, } \\
\text { anaplastic astrocytoma, CLL, } \\
\text { hematological neoplasm }\end{array}$ \\
\hline AT7519 & AT 7519, AT-7519 & $10-210 \mathrm{nM}$ & CDK1,2,4,5,6,9 & $\begin{array}{c}\text { Phase II } \\
\text { NCT02503709 }\end{array}$ & $\begin{array}{l}\text { MM, CLL, MCL, NHL, } \\
\text { solid tumors }\end{array}$ \\
\hline Roniciclib & BAY1000394 & $1-25 \mathrm{nM}$ & CDK1,2,3,4,7,9 & $\begin{array}{c}\text { Phase II } \\
\text { NCT02161419 }\end{array}$ & SCLC \\
\hline RGB-286638 & RGB286638 & $1-5 \mathrm{nM}$ & CDK1,2,3,4,5,9 & $\begin{array}{c}\text { Phase I } \\
\text { NCT01168882 }\end{array}$ & hematological malignancies \\
\hline PHA-793887 & PHA 793887, PHA793887 & 5-10 nM & CDK1,2,4,5,7,9 & $\begin{array}{c}\text { Phase I } \\
\text { NCT00996255 }\end{array}$ & solid tumors \\
\hline SNS032 & BMS-387032, SNS-032 & $48-62 \mathrm{nM}$ & CDK1,2,4,7,9 & $\begin{array}{c}\text { Phase I } \\
\text { NCT00446342 }\end{array}$ & $\begin{array}{l}\text { B-lymphoid malignancies, CLL, } \\
\text { solid tumors }\end{array}$ \\
\hline R547 & Ro 4584820 & $2-3 \mathrm{nM}$ & CDK1,2,3,4,7,9 & $\begin{array}{c}\text { Phase I } \\
\text { NCT00400296 }\end{array}$ & neoplasms \\
\hline Indirubin & Isoindigotin, Indigopurpurin & $0.8-1 \mu \mathrm{M}$ & CDK1,2,4,5 & $\begin{array}{c}\text { Phase IV } \\
\text { NCT02200978 }\end{array}$ & $\begin{array}{l}\text { childhood acute } \\
\text { promyelocytic leukemia }\end{array}$ \\
\hline AZD-5438 & AZD5438; AZD 5438 & $6-20 \mathrm{nM}$ & CDK1,2,4,5,7,9 & $\begin{array}{c}\text { Phase I } \\
\text { NCT00088790 }\end{array}$ & neoplasms \\
\hline CYC065 & CYC-065, CYC 065 & $5 / 26 \mathrm{nM}$ & CDK2,9 & $\begin{array}{c}\text { Phase I } \\
\text { NCT02552953 }\end{array}$ & $\begin{array}{l}\text { AML, MDS, Advanced cancer, } \\
\text { Relapsed/ Refractory CLL }\end{array}$ \\
\hline AG024322 & AG-024322 & $120 \mathrm{nM}$ & CDK1,2,4,6,7,9 & $\begin{array}{c}\text { Phase I } \\
\text { NCT00147485 }\end{array}$ & $\begin{array}{c}\text { neoplasms, } \\
\text { Non-Hodgkin lymphoma }\end{array}$ \\
\hline Voruciclib & P1446A-05 & $22-90 \mathrm{nM}$ & CDK4,6,9 & $\begin{array}{c}\text { Phase I } \\
\text { NCT03547115 }\end{array}$ & CLL/melanoma \\
\hline
\end{tabular}

Indirubin-3-oxime can inhibit the kinase activity of CDK9 to block tyrosine aminotransf erase-mediated expression of human immunodeficiency virus RNA, thereby inhibiting replication of wild-type and drug-resistant HIV-1 [86]. Indirubin-3'-monoxime derivatives serve as potent inhibitors of CDK2 and CDK9 [87]. Indirubin derivate E211, which has already successfully been tested in the clinic, exhibits relatively low inhibitory activity towards various CDKs. Introduction of a sulphonate group into position 5 (E226) very strongly increases inhibitory activity with an IC50 value toward CDK1/cyclinB of only $5 \mathrm{nM}$ [88]. Unfortunately, E226 was found not to penetrate cellular membranes to any measurable extent and therefore did not show comparable inhibitory effects towards CDK in cells, nor did it show any cell growth inhibition. When the sulphonate group was replaced by a N,N-dimethyl sulphonamide group (E233) the inhibitory potency towards isolated CDK1 and CDK2 remained extremely high. Still, the compound was found not to be taken up sufficiently into tumor cells, and therefore showed only poor growth inhibition [89]. Indirubin is also known to be a potent inhibitor of CDK6, the Ser/Thr kinase with regular activity in the cell cycle. It exhibits high binding affinity [90]. In total, there are six clinical studies on indirubin for patients with psoriasis vulgaris, nail psoriasis, atopic dermatitis and Childhood Acute Promyelocytic Leukemia. For acute promyelocytic leukemia (APL) there is an ongoing phase 4 clinical trial (NCT02200978). These studies showed that this agent was effective against APL. Indirubin is relatively inexpensive and can be taken orally, resulting in reducing the number of hospital days and the treatment cost.

\subsection{Problems and Limitations of Pan-CDK Inhibition}

There are several reasons that may explain why the non-selective inhibitors did not lead to success in clinical application. The lack of specificity is the most obvious one. Especially the consequential insufficient understanding of the complex underlying mechanisms of action of the respective drugs makes the failure hard to explain. This lack of understanding hinders the progression of these agents to be targeted therapies and 
the development of effective combination strategies. Moreover, due to their non-specific mode of action, a wide variety of cellular effects occur. This fact makes it difficult to predict the final therapeutic outcome in the patient. It is indeed these multiple and diverse, unpredictable mechanisms of action that lead to normal cells being affected in addition to tumor cells. This in turn creates a strong impediment to achieving a proper therapeutic window and therapeutically effective concentrations high enough to destroy tumor cells. Accordingly, there have been side effects and toxicities associated with non-selective CDKIs including diarrhea, myelosuppression, anemia, hepatic dysfunction and nausea [72,76,91].

Another important reason for the missing clinical success of non-specific CDKIs is the lack of biomarkers to select patient subpopulations which were particularly sensitive to CDKIs. Clinical trials showed that there were some exceptional responders, but it was inconclusive what the exact underlying condition was. It is possible-we are seeing this in our research-that the mechanism of action is highly dependent on the hetero- or homogeneity of the tumor mass as well as the molecular cell cycle machinery, which varies depending on the tumor environment. So, it could be assumed that there are certain time frames which are important for therapeutic use.

Although non-specific pan-CDKIs have shown disappointing clinical results in a broad range of applications, there is nevertheless some evidence that non-specific pan-CDKIs are also actually effective in a limited range of applications. The known limitations of pan-CDKIs suggest that improving selectivity for specific CDKs is pivotal to the successful development of CDKIs as cancer therapeutics. With the development of specific CDKIs, the potential for these drugs to be deployed in broad clinical use gained great momentum.

Interestingly, recent studies have shown that combination therapies, in contrast to CDKI monotherapies, can provide promising results in tumor therapy. In some tumor entities, a combination of conventional treatment and CDK inhibition has already been shown to reverse treatment resistance, such as radio- or chemoresistance. This relationship will be discussed in more detail later along in this review. It is particularly discussed for HNSCC, a tumor entity with little improvement in treatment outcomes for decades despite medical advances in recent years.

\section{Development of Selective CDK Inhibitors}

Due to their ubiquitous biological functions pan-selective CDKs are of limited use as clinical targets. Complex pharmacokinetics and dose-limiting toxicities have complicated the use of CDKIs. Due to the insurmountable adverse effects and reduced activity observed in vivo, the development of many CDKIs, which initially displayed reliable results in vitro and in Phase I studies, was eventually discontinued. Because of the narrow therapeutic window, specific CDKIs are necessary to provide an effective cancer treatment with reduced side effects. Some of them have already been evaluated for their efficacy, experimentally as well as clinically. For an overview of selected specific CDKIs see Table 3. Some of the specific CDKIs are currently investigated in ongoing clinical trials, as indicated in the table.

Table 3. Overview of selected specific CDK inhibitors.

\begin{tabular}{|c|c|c|c|c|c|c|}
\hline Compound & $\mathrm{IC}_{50}$ & Target & Progress & $\begin{array}{l}\text { Number } \\
\text { of Trials }\end{array}$ & Application & Literature \\
\hline Sorafenib & $6 \mathrm{nM}$ & CDK1 & $\begin{array}{l}\text { Phase IV } \\
\text { NCT02733809, } \\
\text { NCT02504983, } \\
\text { NCT03518502 }\end{array}$ & 3 & $\begin{array}{c}\text { hepatocellular carcinoma, } \\
\text { fibrolamellar, } \\
\text { leukemia, thyroid }\end{array}$ & [92] \\
\hline RO3306 & 20-1980 nM & CDK1 & $\begin{array}{c}\text { n.a. } \\
\text { Phase III }\end{array}$ & n.a. & n.a. & [93] \\
\hline HI 5 & $6 \mu \mathrm{M}$ & CDK2 & $\begin{array}{l}\text { NCT01566695 } \\
\text { NCT04143451 } \\
\text { NCT04266301 }\end{array}$ & 6 & Leukemia, renal carcinoma & [94] \\
\hline Palbociclib & $11 / 16 \mathrm{nM}$ & CDK4/6 & Phase IV & 2 & breast cancer & [95] \\
\hline
\end{tabular}


Table 3. Cont.

\begin{tabular}{|c|c|c|c|c|c|c|}
\hline Compound & $\mathrm{IC}_{50}$ & Target & Progress & $\begin{array}{l}\text { Number } \\
\text { of Trials }\end{array}$ & Application & Literature \\
\hline Ribociclib & $10 / 39 \mathrm{nM}$ & CDK $4 / 6$ & $\begin{array}{l}\text { NCT03355157, } \\
\text { NCT03220178 }\end{array}$ & 10 & breast cancer & [96] \\
\hline Abemaciclib & $2 / 10 \mathrm{nM}$ & CDK4/6 & Phase III & 1 & breast cancer & [97] \\
\hline Trilaciclib & $1 / 4 \mathrm{nM}$ & $\mathrm{CDK} 4 / 6$ & NCT02422615 & 1 & SCLC & [98] \\
\hline SHR6390 & $12 \mathrm{nM} / 10 \mu \mathrm{M}$ & CDK4/6 & $\begin{array}{c}\text { NCT01958021 } \\
\text { Phase II }\end{array}$ & 3 & breast cancer & [99] \\
\hline G1T38/Lerociclib & $1 \mathrm{nM} / 2 \mathrm{nM}$ & CDK $4 / 6$ & $\begin{array}{l}\text { NCT02983071, } \\
\text { NCT03455829 }\end{array}$ & 2 & breast cancer, NSCLC & [100] \\
\hline $\begin{array}{c}\text { XZP- } \\
\text { 3287/Birociclib }\end{array}$ & n.a. & CDK $4 / 6$ & $\begin{array}{c}\text { Phase II } \\
\text { NCT04539496 } \\
\text { Phase I }\end{array}$ & 1 & breast cancer, solid tumors & [101] \\
\hline SY5609 & $<6 \mathrm{nM}$ & CDK7 & $\begin{array}{l}\text { NCT04247126, } \\
\text { NCT04929223 }\end{array}$ & 2 & breast, NSCLC, colorectal, & {$[102]$} \\
\hline XL102 & n.a. & CDK7 & $\begin{array}{c}\text { Phase I } \\
\text { NCT04726332 }\end{array}$ & 1 & breast, ovarian, prostate & n.a. \\
\hline $\begin{array}{l}\text { LDC3140, LDC4297, } \\
\text { THZ1, THZ2 }\end{array}$ & $0.13 \mathrm{nM}$ & CDK7 & n.a. & n.a. & n.a & {$[103]$} \\
\hline RVU120 & $4.4 / 10.4 \mathrm{nM}$ & CDK8/19 & $\begin{array}{c}\text { Phase I } \\
\text { NCT04021368 }\end{array}$ & 1 & acute Myeloid Leukemia & n.a. \\
\hline $\begin{array}{l}\text { cortistatin A, } \\
\text { CCT251545, } \\
\text { CCT251921, } \\
\text { MSC2530818 }\end{array}$ & $100 \mathrm{nM}$ & CDK8/19 & n.a. & n.a. & n.a. & [104-109] \\
\hline AZD4573 & $<3 \mathrm{nM}$ & CDK9 & $\begin{array}{c}\text { Phase II } \\
\text { NCT04630756 }\end{array}$ & 1 & $\begin{array}{l}\text { advanced hematological } \\
\text { malignancies }\end{array}$ & \\
\hline ТР-1287 & n.a. & CDK9 & $\begin{array}{c}\text { Phase I } \\
\text { NCT03604783 }\end{array}$ & 1 & solid tumors, sarcoma & [110] \\
\hline GFH009 & n.a. & CDK9 & $\begin{array}{c}\text { Phase I } \\
\text { NCT04588922 }\end{array}$ & 1 & $\begin{array}{l}\text { hematologic malignancies, } \\
\text { AML, CML, SLL, lymphoma }\end{array}$ & [111] \\
\hline KB-0742 & $6 \mathrm{nM}$ & CDK9 & $\begin{array}{c}\text { Phase I } \\
\text { NCT04718675 } \\
\text { Phase II }\end{array}$ & 1 & $\begin{array}{c}\text { solid tumors, } \\
\text { Non-Hodgkins Lymphoma }\end{array}$ & [112] \\
\hline Fadraciclib & $26 \mathrm{nM}$ & CDK9 & $\begin{array}{l}\text { NCT04983810, } \\
\text { NCT05168904 }\end{array}$ & 2 & $\begin{array}{c}\text { solid tumor, } \\
\text { leukemia, lymphoma }\end{array}$ & [113] \\
\hline SR-4835/THZ531 & $4.9 \mathrm{nM}$ & CDK12/13 & n.a. & n.a. & n.a. & [114] \\
\hline
\end{tabular}

\subsection{CDK1 Inhibitors}

CDK1 is one of the main cell cycle regulators and a key factor of mitosis. A CDK1 knockdown is already lethal in the early cell division stages [115]. Therefore, CDK1 inhibition may be toxic in certain contexts. It may also be difficult to find a therapeutic window for CDK1 inhibitors in which exclusively tumor cells are targeted, excluding the normal, non-malignant cells. Targeting CDK1 might be selectively lethal to MYC-dependent human breast cancer cells [116]. Nevertheless, a limited number of studies have been conducted. CDK1 inhibitor RO3306 in combination with sorafenib treatment significantly decreased tumor growth in patient derived xenograft (PDX) tumor models. Furthermore, the combinatorial treatment could overcome sorafenib resistance in a preclinical PDX model of HCC [93]. The molecular structure of CDK1 inhibitors RO3306 and sorafenib are shown in Figure 9.
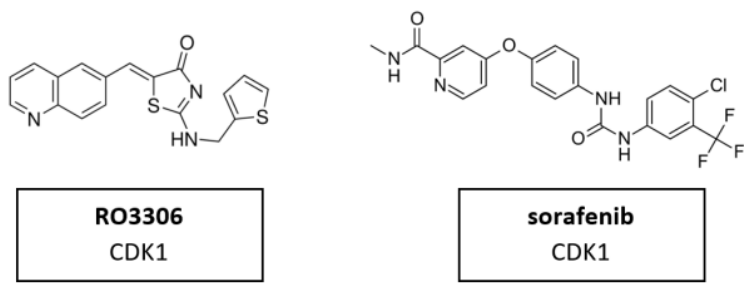

Figure 9. Structure of CDK1 inhibitors RO3306 and sorafenib. 


\subsection{CDK2 Inhibitors}

Due to its crystallographic structure availability, initial efforts for second-generation CDKIs were primarily focused on inhibition of CDK2, which is essential for DNA replication [94]. A recent in vitro study demonstrated a new CDK2 inhibitor with 3-hydrazonoindolin-2-one scaffold, called HI 5 (Figure 10). This inhibitor induced intrinsic apoptosis in human breast cancer cell line MCF-2 [117].

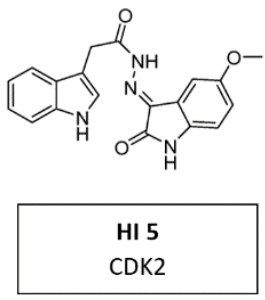

Figure 10. Structure of CDK2 inhibitor HI 5.

Since CDK7, CDK8/19, CDK12/13, or CDK9 are associated with basal RNA transcription, it seemed a reasonable strategy to selectively target these CDKs, as cancer cells may be particularly susceptible to selective suppression (Figure 8).

The following CDK inhibitors affect $\mathrm{CDKs}$ which are thought to be relevant in regulating the action of RNA polymerase II (Figure 3).

\subsection{CDK4/6 Inhibitors}

The development of selective inhibitors, of both CDK4 and CDK6, has markedly changed the perception of CDKs as therapeutic targets in cancer. Dual CDK4 and CDK6 inhibitors have been shown to be active in multiple preclinical models, including xenografts, genetically engineered mouse models and primary human tumor explants. Parallel drug discovery efforts at Pfizer, Eli Lilly and Novartis resulted in the development of the drugs palbociclib (PD-0332991), ribociclib (LEE011) and abemaciclib (LY2835219), respectively $(15)[118,119]$. Each drug is structurally similar, and the selectivity of these compounds is characterized by binding to the specialized ATP-binding pocket of CDK4 and CDK6 and specific interactions with residues in the ATP-binding cleft [120]. All three compounds were evaluated through chemical screening and optimization by adding pyrido[2,3-d] pyrimidin7-one compounds with a side chain of 2-amino pyridine at the C2 position of CDKIs. The pyrido[2,3-d]pyrimidin-7-one template has been identified previously as a privileged structure for the inhibition of ATP-dependent kinases [121]. Palbociclib, ribociclib, and abemaciclib are administered orally and have limited suppression of other CDK activities at clinically achievable doses. These inhibitors are structural analogues to flavopiridol, but have different chemical functions [122]. CDK4/6 inhibitors contribute to G0/G1 phase cell cycle arrest by preventing the phosphorylation of $\mathrm{pRb}$ which leads to the inhibition of tumor progression in a variety of cancers (see Figures 1 and 2). Therefore, it is assumed that in HNSCC, CDK4/ 6 inhibitors showed best results in HPV-negative HNSCC with high $\mathrm{Rb}$ expression and an epithelial phenotype. Despite oncogenic signals that are insensitive to endocrine therapy, CDK4/ 6 inhibitors effectively prevent cell cycle progression and mitosis [123]. These three CDK4/6 inhibitors are described in more detail in the following paragraphs. Their molecular structure is shown in Figure 11.

\subsubsection{CDK4/6 Inhibitor Palbociclib}

Palbociclib, also known as PD 0332991, was the first CDK4/ 6 inhibitor to be approved in cancer therapy [124]. This selective CDK4/ 6 inhibitor prevents phosphorylation of the $\mathrm{Rb}$ protein and subsequently downregulates the $\mathrm{E} 2 \mathrm{~F}-$ driven gene, leading to cell cycle arrest in G1 phase. Additionally, it downregulates Ki-67 expression in Rb-positive models. In xenografts of Rb-negative tumors this effect could not be detected [125]. Interestingly, it was found to sensitize cancer cells to other therapeutic treatments when applied as 
combination therapy, such as chemotherapy [123] and ionizing radiation [126]. The potent anti-tumor effects of palbociclib have been observed in several tumor types, including $\mathrm{T}$ cell acute lymphoblastic leukemia (T-ALL) [127], HCC [128], neuroblastoma [129], RCC [130], myeloma [131], MCL [132], pancreatic ductal adenocarcinoma [133], esophageal adenocarcinoma [134], medulloblastoma [126], melanoma [135], NSCLC [136], and particularly in breast cancer [137]. Palbociclib was approved by the FDA in 2015 in combination with letrozole as initial hormone- plus CDK-targeted therapy for post-menopausal women with $\mathrm{ER}(+) /$ Her2(-) advanced breast cancer [95]. Moreover, the therapeutic effects of palbociclib have been demonstrated in numerous clinical trials for breast cancer, NSCLC, Goodpasture's Syndrome, lymphoma and leukemia, in combination with 5-FU and oxaliplatin in solid malignancies (NCT01522989) or with cetuximab, a monoclonal antibody against the epidermal growth factor receptor (EGFR), in HNSCC [138,139].
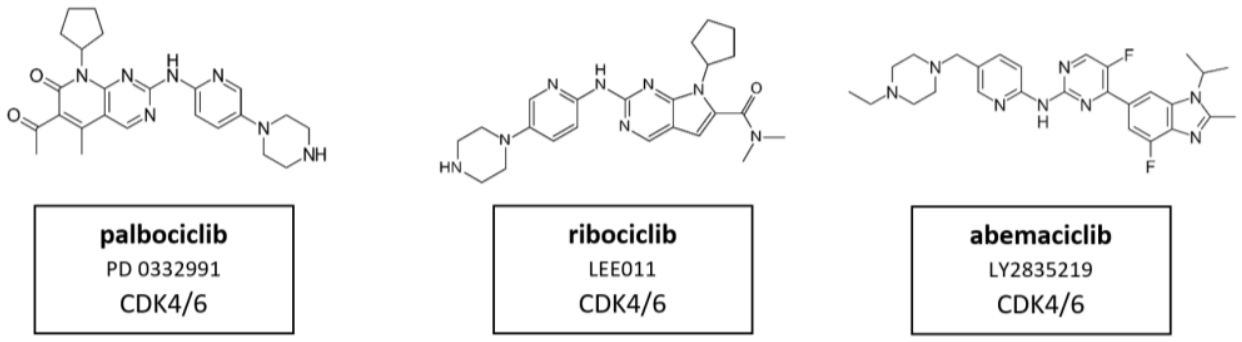

Figure 11. Structure of the specific CDK4/6 inhibitors palbociclib (also known as PD 0332991), ribociclib (also known as LEE011) and abemaciclib (also known as LY2835219).

Palbociclib has also been studied in multiple animal models of a wide variety of tumor types, including liver cancer [128], glioblastoma multiforme [140], pancreatic neuroendocrine tumors [141], gliomas [142], colon carcinoma [143] breast cancer [144]. This compound led to growth arrest of xenograft tumors and prolonged survival of treated animals. Mice models with ERBB2-overexpressing breast carcinoma showed that CDK4/ 6 was pivotal to the maintenance of the disease.

Phase I trials evaluated palbociclib in patients with $\mathrm{Rb}$-positive tumors. These studies exhibited the dose-limiting toxicity (DLT) of palbociclib to be neutropenia and the maximum tolerated dose (MTD) was $125 \mathrm{mg}$ daily for 21 days per 28-day cycle or $200 \mathrm{mg}$ daily for 14 days per 21-day cycle $[145,146]$.

Currently there is an ongoing biomarker-based study called UPSTREAM, of the European Organization for Research and Treatment of Cancer-EORTC, for HNSCC. The umbrella biomarker-driven study is dedicated to recurrent and/or metastatic HNSCC patients. It is the first multicenter pilot study proposing a therapeutic strategy based on biomarkers in patients with recurrent/metastatic HNSCC, palbociclib is indicated in patients with cyclin D1 (CCND1) amplification and p16 negativity [147].

\subsubsection{CDK4/6 Inhibitor Ribociclib}

The mode of action of ribociclib, also known as LEE011, has been investigated in numerous in vitro studies, particularly in cancers such as leukemia [148], neuroblastoma [149], neuroendocrine tumors [150], liposarcomas [151], breast cancer [152] and HNSCC [153].

The efficacy of ribociclib was also assessed in animal models bearing multiple cancer types including breast cancer [154], neuroblastoma [129], liposarcoma [151] and HNSCC. Tumor size stabilization was observed in three HPV-negative PDTX models and tumor growth was delayed in one HPV-negative tumor compared with controls. Although its volume increased over time under ribociclib treatment two tumors were resistant to the CDKI treatment [153]. 


\subsubsection{CDK4/6 Inhibitor Abemaciclib}

Abemaciclib, also known as LY2835219, is the third selective CDK4/ 6 inhibitor, which has been studied in several tumors to date, including breast cancer [155], melanoma [156], bladder cancer [157] and oral squamous cell carcinoma (OSCC). In OSCC, this inhibitor was evaluated in a phase I study. The clinically most significant adverse event was grade 3 fatigue. The maximum tolerated dose was $200 \mathrm{mg}$ every $12 \mathrm{~h}$. Current data suggest that abemaciclib can penetrate the central nervous system with potential interest in the treatment of brain metastases. At the molecular level, abemaciclib inhibits the activation of AKT and ERK, but not mTOR. Abemaciclib has also been reported to decrease ABC transporterinduced resistance of tumor cells to chemotherapeutic agents. Its treatment significantly sensitized $A B C B 1$ or ABCG2 overexpressing cancer cells by impairing the functions of $\mathrm{ABCB} 1$ and ABCG2 in these transporter-amplified cancer cells [155]. The combination of abemaciclib with everolimus, an mTOR inhibitor, proved to have more efficacy than abemaciclib in monotherapy in a recent study and seems a promising therapeutic approach for HNSCC [158].

CDK4/ 6 inhibitors may also exert systemic effects and can therefore lead to adverse side effects such as thrombosis or pulmonary embolism. In addition, the formation of resistance has been reported $[159,160]$. These limitations led to the exploration of alternative strategies to reduce increased kinase activity in cancer cells.

\subsubsection{CDK4/6 Inhibitor Trilaciclib}

Trilaciclib (Figure 12) is a small molecule, short-acting CDK4/ 6 inhibitor. It was proven for its myeloprotection and potential antitumor efficacy and safety in combination with cancer chemotherapy [98]. In February 2021, trilaciclib received its first approval in the U.S. to reduce chemotherapy-induced myelosuppression in adult patients when administered prior to platinum/etoposide-containing or topotecan-containing chemotherapy for advanced-stage small cell lung cancer (ES-SCLC) [161]. Clinical trials in breast cancer, colorectal cancer and small cell lung cancer are currently underway in several countries.

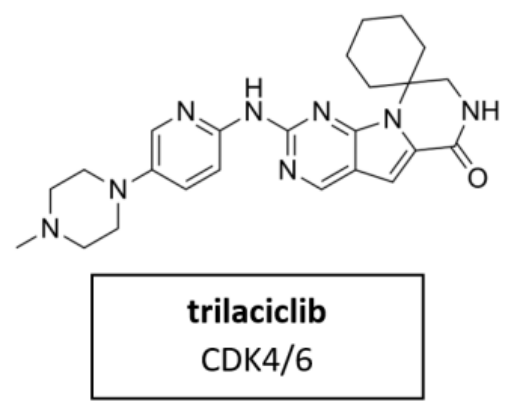

Figure 12. Structure of the novel specific CDK4/6 inhibitor trilaciclib.

\subsection{CDK7 Inhibitors}

Several compounds have shown potential as promising selective inhibitors of CDK7. These include LDC3140 and LDC4297, THZ1 and THZ2 (Figure 13). The high specificity of these inhibitors derives from their ability to interact with a cysteine residue outside the catalytic domain of CDK7, which is absent in other CDKs. These inhibitors, when used to treat tumor cells, showed preferential impacts on RNA polymerase II activities [103]. They have anti-tumor activity in multiple tumor types, including aggressive and heterogeneous cancers, such as neuroblastoma, small cell lung cancer and triple-negative breast cancer, with poorly defined oncogenic driver mutations [162]. These tumors had in common an amplification of one of the MYC family members. Regions of high transcription activity have clusters of enhancers, known as super-enhancers. It is assumed the responsiveness of cells to these inhibitors are due to the sensitivity of super-enhancers to CDK7 inhibition [103]. 

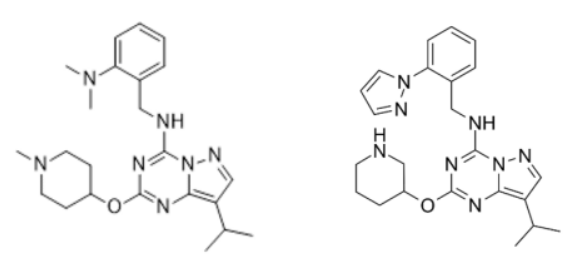

LDC3140 CDK7
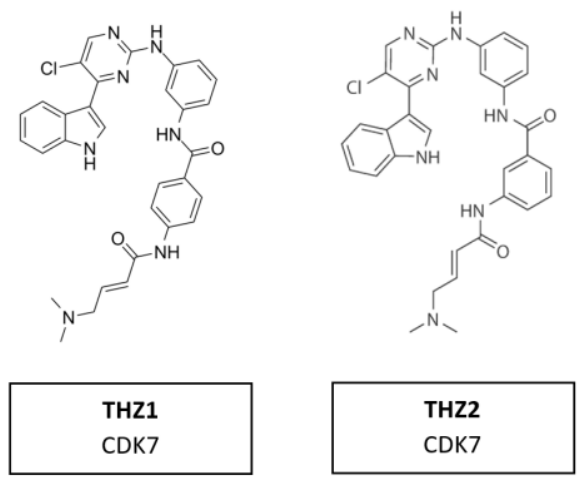

Figure 13. Structure of CDK7 inhibitors LDC3140, LDC4297, THZ1 and THZ2.

\section{CDK7 Inhibitor SY-5609}

CDK7 has emerged as a target of interest in oncology due to its role in two important processes that are dysregulated in cancer cells-cell cycle and transcription. SY-5609 (Figure 14) the discovery of a highly potent (sub-nM) and selective orally available CDK7 inhibitor. It was introduced to the clinic in 2020 (NCT04247126). Structure-based design was leveraged to obtain high selectivity (>4000-times the closest off target) and slow off-rate binding kinetics desirable for potent cellular activity. The incorporation of a phosphine oxide as an atypical hydrogen bond acceptor helped to achieve the required potency and metabolic stability. SY-5609 exhibits potent inhibition of CDK7 in cells and demonstrates strong efficacy in mouse xenograft models at doses as low as $2 \mathrm{mg} / \mathrm{kg}$ [102].

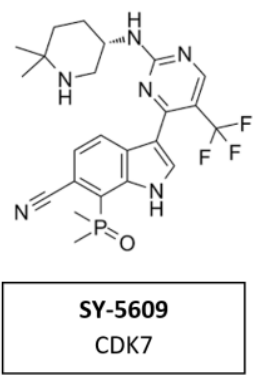

Figure 14. Structure of the specific CDK7 inhibitor SY-5609.

\subsection{CDK8/19 Inhibitors}

The transcription regulators CDK8 and CDK19 have 91\% sequence homology over the first 370 residues - which encompass the active site-but differ substantially toward the Cterminus in areas that may contribute to their non-redundant functions [163]. This suggests that the active site of those two proteins is remarkably similar and compound selectivity is a challenge. A whole series of CDK8/CDK19 inhibitors have been found. Cortistatin A (Figure 15) is a steroidal alkaloid isolated from the marine sponge Corticium simplex. Cortistatin A has a $17 \mathrm{nM}$ binding affinity to CDK8 and $10 \mathrm{nM}$ to CDK19 [104]. A further study identified anti-leukemic activity of cortistatin A, in vitro and in vivo, which inhibited CDK8/19 and induced the expression of superenhancer-associated genes in sensitive cell lines [105]. Additional studies revealed CCT251545 (Figure 15), a type I binding molecule, as potent small-molecule inhibitors of WNT signaling with a single-digit $\mathrm{IC}_{50}$ for $\mathrm{CDK} 8$ of $5 \mathrm{nM}$ and CDK19 of $6 \mathrm{nM}$ [106]. Additional CDK8/19 inhibitors have been reported in the literature, including a series of 6-aza-benzothiophene containing compounds that were developed into potent selective Type I inhibitors of CDK8 [107]. After the discovery of CCT251545 follow-up work yielded a 3,4,5-trisubstituted-2-aminopyridine series exemplified by CCT251921 (Figure 15). This compound is a potent selective and orally bioavailable inhibitor of CDK8, with equal affinity for CDK19 and optimal biochemical, pharmacokinetic and physicochemical properties [108]. However, the latter exhibited a pleiotropic toxicolog- 
ical profile, which rendered it impossible to find a therapeutically useful window in clinical trials. Further studies led to the discovery of MSC2530818 (Figure 15) a compound with excellent kinase selectivity, biochemical and cellular potency, microsomal stability and oral bioavailability [109]. However, the latter exhibited a pleiotropic toxicological profile, which rendered it impossible to find a therapeutically useful window in clinical trials.
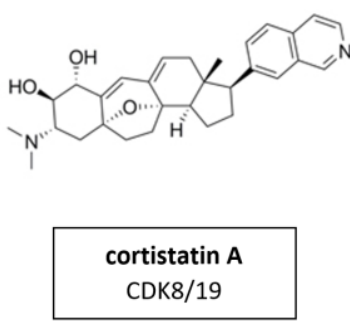

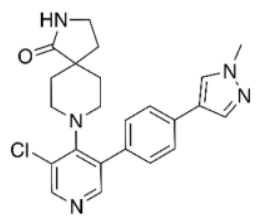

CCT251545 CDK8/19

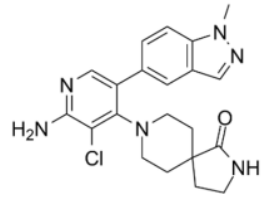

ССТ251921 CDK8/19

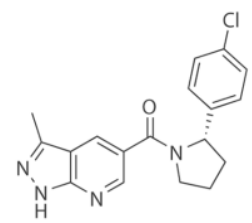

MSC2530818 CDK8/19

Figure 15. Structure of CDK8/19 inhibitors cortistatin A, CCT251545, CCT251921 and MSC2530818.

\subsection{CDK9 Inhibitors}

A range of CDK7/9 inhibitors with different selectivity profiles have been identified. This included CDKI-71 and CDKI-73 (Figure 16), a novel class of 5-substituted-4-(thiazol-5yl)-2-(phenylamino) pyrimidines [164]. CDKI-71 showed cytotoxicity and induced caspasedependent apoptosis in human cancer cell lines, primary patient leukemia cells, B and $\mathrm{T}$ cells as well as embryonic lung fibroblasts. Notably, compared with the unselective alvocidib, CDKI-71 preferentially affected cancer cells [165]. Treating primary human leukemia cells with CDKI-73 has been shown to lead to the dephosphorylation of CDK9, the dephosphorylation of the RNA polymerase II CTD at Ser2 and to induce caspasedependent apoptosis. CDKI-73 was more potent than the pan-CDKI alvocidib, showing selectivity for primary leukemia cells over normal CD34+ cells and was synergistic with fludarabine [166]. Treatment with LDC000067 (Figure 15) has been shown to increase the pausing of RNA polymerase II and to lead to a selective reduction in short-lived mRNAs, including those encoding regulators of proliferation and apoptosis. Nemeth et al. evaluated a highly potent inhibitor which was proven to be highly specific to CDK9/CycT1 and acts in an ATP-competitive manner. The inhibitory capacity of the compound and its high specificity for CKD9/CycT1 is exceptional. Results suggested it would have the potential to control HIV-1 replication in vivo while having a lower risk of inhibiting other kinases and consequently causing undesired toxicity [167].
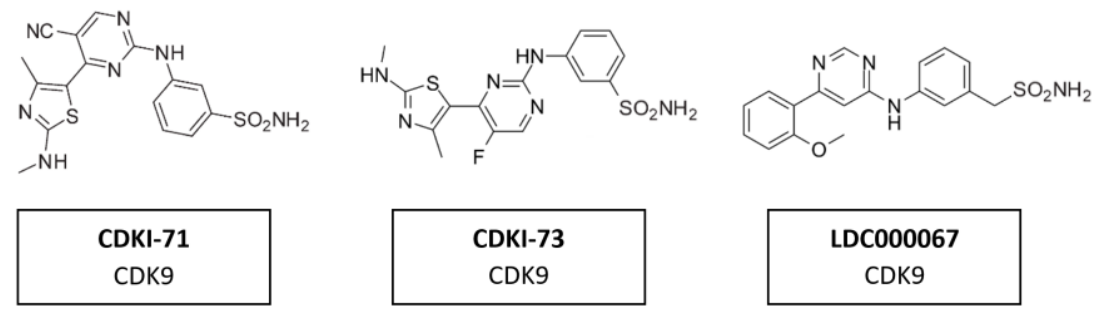

Figure 16. Structure of CDK9 inhibitors CDKI-71, CDKI-73 and LDC000067.

\subsection{CDK9 Inhibitor AZD4573}

CDK9 is a transcriptional regulator and potential therapeutic target for many cancers. Multiple nonselective CDK9 inhibitors have progressed clinically but were limited by a narrow therapeutic window. AZD4573 (Figure 17) is a novel, potent, and highly selective CDK9 inhibitor. It enables the indirect inhibition of MCL-1, providing a therapeutic option for MCL-1-dependent diseases. Currently, AZD4573 is being evaluated in phase I and II clinical trial for patients with hematologic malignancies (NCT03263637, NCT04630756, NCT05140382) [168]. 


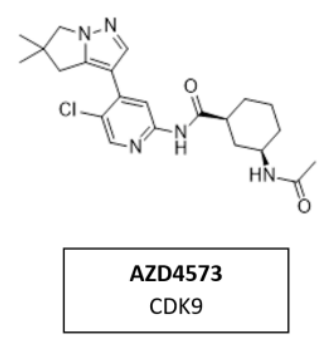

Figure 17. Structure of the specific CDK9 inhibitor AZD4573.

CDK12/13 Inhibitors

CDK12 phosphorylates the CTD region of RNA polymerase II promoting transcription elongation [169]. Several inhibitors, like SR-4835 and THZ531 (Figure 18), demonstrated strong anti-tumor activity in preclinical studies. SR-4835 is a highly selective dual inhibitor of CDK12 and CDK13, which can suppress the expression of core DNA damage response proteins and can thereby promote a synergistic effect of DNA damage chemotherapy and PARP inhibitors in triple negative breast cancer [170]. THZ531 is another covalent inhibitor of CDK12 and CDK13, which can significantly down-regulate the expression of DNA damage response genes and key super-enhancer-related transcription factors [114]. THZ531 has a synergistic effect with sorafenib in the treatment of hepatocellular carcinoma [171]. To date, the inhibitors targeting CDK12 in clinical trials have all been pan-CDKIs, including dinaciclib.
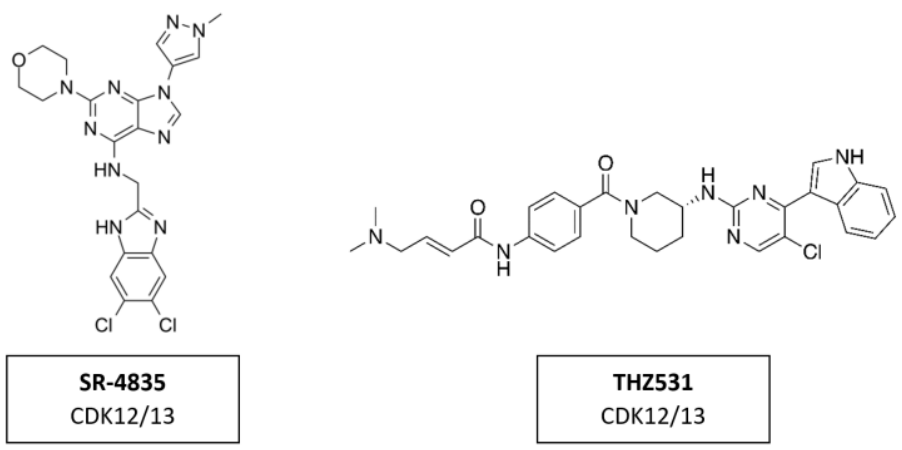

Figure 18. Structure of CDK12/13 inhibitors SR-4835 and THZ2531.

\subsection{Problems and Limitations of Selective CDK4/6 Inhibitors Resistance Mechanisms}

Primary drug resistance is a clinical situation in which a malignant tumor does not respond to chemotherapy. Approximately $10 \%$ of patients will have primary resistance to $\mathrm{CDK} 4 / 6$ inhibitors. In the future, biomarkers may have the potential to identify these types of patients at baseline or shortly after treatment initiation, facilitating earlier switch to a more effective treatment. For instance, patients with evidence of functional $\mathrm{Rb}$ loss at baseline are not likely to benefit from CDK4/ 6 inhibition. For breast cancer, various preclinical studies suggested loss of $\mathrm{Rb}$ to be a driver of resistance to CDK4/6 inhibitors [172,173]. Similarly, baseline evidence of increased cyclin E1 expression or the CCNE1/RB ratio may also play a role in identifying these patients $[159,174]$.

Peripheral evidence of ongoing neoplastic proliferation, as manifested by a rise in TK1 activity within a month of commencing therapy, may also provide a marker of early resistance.

One question that remains to be explored concerns the ongoing treatment with CDK4/6 inhibitors after disease progression with these compounds. The prospect that continuing a CDK4/6 inhibitor beyond disease progression may be an effective strategy is being explored in several ongoing phase 1 and phase 2 trials (MAINTAIN NCT02632045, PACE NCT03147287, NCT01857193, NCT 02871791, and TRINITI-1 NCT 02732119). Mutations in RB1, resulting in activation of other cell cycle factors, such as E2F and the Cyclin 
E/CDK2 axis, has been demonstrated in cases of acquired CDKIs resistance, which by definition would qualify as a secondary resistance. $[175,176]$. This in turn results in independence from the CDK4/6 pathway for cell cycle progression from G1 to S phase. In such cases, in the setting of disease progression on a CDK4/6 inhibitor, concurrent biomarker evidence of a functional loss of $\mathrm{Rb}$ may support a switch to a new agent, rather than continuing CDK4/6 agents beyond progression. Moreover, the elevation of CDK6 has also been associated with resistance to CDK4/6 inhibitors, revealing an additional potential mechanism of resistance $[176,177]$. Furthermore, the PI3K/mTOR pathway has been shown to be upregulated in response to chronic exposure to CDK4/6 inhibitors, which in turn upregulates cyclin D. In the absence of CDK4 and CDK6, activated cyclin D can activate CDK2, which subsequently drives cell cycle progression [159]. Functioning downstream of PI3K is 3-phosphoinositide-dependent protein kinase 1 (PDK1), a vital requisite for the full activation of AKT [178]. The PI3K-PDK1 signaling pathway has been implicated in mediating resistance to CDK4/6 inhibitors, with ribociclib-resistant breast cancer cell lines demonstrating an increase in PDK1 levels following drug exposure, resulting in activation of the AKT pathway [179].

\section{Synergistic Effects of CDKI Treatment with a Focus on HNSCC}

\subsection{General Description of Molecular Settings Their Response to CDK Inhibitors}

In the following chapter, the advantages of combining the partly quite disappointing outcomes of CDKI monotherapy together with standard therapies such as radio-, chemo-, targeted or even immunotherapy in various tumor types will be highlighted. Indeed, there is a clear tendency towards a synergistic effect of CDKIs, which may ultimately lead to sensitization of radio- and chemoresistance as well as a sensitization to immune checkpoint blockade. The synergistic effects that contribute overcoming resistance have been observed in several experimental studies and early clinical trials.

The synergistic effect of CDKIs in combination with radio-, chemo-, targeted or even immunotherapy effect has been reported in HNSCC, as well as in ovarian, prostate, and non-small cell lung cancer. In the following, we particularly focus on HNSCC. HNSCC represents the eighth most common form of cancer worldwide. Nearly 800,000 new diagnoses are made annually, with a large increase in incidence over the past 10 years. Despite remarkable progress over the last decades, the 5 year overall survival rate of patients with HNSCC is still about 50\% [3]. For targeted treatment, HNSCC need to be divided into two major subgroups with respect to their oncogenesis, resulting in molecular differences: human papillomavirus (HPV)-negative and HPV-positive HNSCC.

In HPV-negative HNSCC, the CCND1/CDK4/6-CDKN2A (p16 ${ }^{\mathrm{INK} 4 \mathrm{~A}}$ ) Rb pathway is affected by amplification of CCND1 (in 20-30\% of cases) and inactivation of p16 ${ }^{\mathrm{INK} 4 \mathrm{~A}}$ (in approximately $90 \%$ of cases), which results in inactivation of the $\mathrm{pRb}$ protein by hyperactivation of the cyclin D/CDK4/6 complex [180]. CDKN2A, that encodes cyclin-dependent kinase inhibitor $\mathrm{p} 16^{\mathrm{INK} 4 \mathrm{~A}}$, is frequently inactivated by a copy number loss in HPV-negative HNSCC [181,182]. In contrast, p16 ${ }^{\mathrm{INK} 4 \mathrm{~A}}$ overexpression is typical for HPV-positive HNSCC [17] and used as a surrogate marker of HPV infection [182].

It has been shown that CCND1 amplification and inactivation of $\mathrm{p} 16^{\mathrm{INK} 4 \mathrm{~A}}$ are markers for poor prognosis in HNSCC partly because overexpression of CCND1 decreases tumor response to cisplatin [183] and EGFR inhibitors [184].

In HPV-positive HNSCC, the viral oncogenes E6 and E7 are associated with reduced $\mathrm{pRb}$ and $\mathrm{p} 16^{\mathrm{INK} 4 \mathrm{a}}$ overexpression. Wiest et al. showed that the E7 oncogene of the HPV16 subtype induces a functional inactivation of $\mathrm{pRb}$ [185]. Consequently, CDK4/6 inhibitors may only be beneficial in patients with p16/HPV16-negative HNSCC.

The finding that the CCND1/CDK4/6-CDKN2A (p16 $\left.{ }^{\mathrm{INK} 4 \mathrm{~A}}\right) \mathrm{Rb}$ axis is altered in a substantial number of HNSCC cases provides hope for specific CDK4/6 inhibitors to achieve good therapeutic efficacy. 


\subsection{Clinical Phase Trials with CDKI Combination Therapies}

This discovery of specific CDK targets will hopefully expand treatment options for patients by using CDKIs in monotherapy or in combination with radio-, chemo-, and immunotherapy, preventing treatment resistance. The addition of CDK4/ 6 inhibitors to several established treatments for HNSCC has the potential to improve responses to other therapies and may help overcome resistance.

CDK4/6 inhibitors in monotherapy have demonstrated cytostatic activity in HPVnegative HNSCC. However, several studies on monotherapies have shown potent antitumor activity and manageable toxicity in HR+/HER2-breast cancer patients. In contrast monotherapy in HNSCC demonstrated only relatively poor results so far [97]. Despite preclinical success, monotherapies targeting EGFR or cyclin D1-CDK4/ 6 in HNSCC have shown a limited clinical outcome [186].

At present, several clinical trials of CDK4/ 6 inhibitors are ongoing for patients with HNSCC. Table 4 lists the most important clinical trials currently in progress.

Table 4. Ongoing studies of CDK 4/6 therapies in HNSCC (from clinicaltrials.gov, 2021).

\begin{tabular}{|c|c|c|c|c|c|c|c|}
\hline $\begin{array}{l}\text { Study } \\
\text { Type }\end{array}$ & $\begin{array}{l}\text { Study } \\
\text { Status }\end{array}$ & $\begin{array}{l}\text { NCT } \\
\text { Number }\end{array}$ & $\begin{array}{l}\text { Tumor } \\
\text { Entity }\end{array}$ & $\begin{array}{c}\text { Title/ } \\
\text { Intervention }\end{array}$ & $\begin{array}{l}\text { Treatment } \\
\text { Schedule }\end{array}$ & $\begin{array}{l}\text { Primary } \\
\text { Outcome }\end{array}$ & Results \\
\hline $\begin{array}{l}\text { Open-label, } \\
\text { single arm, } \\
\text { Phase II }\end{array}$ & Recruiting & 03356223 & HNSCC & $\begin{array}{l}\text { Abemaciclib monotherapy } \\
\text { for locally advanced/ } \\
\text { metastatic HNSCC after } \\
\text { failure of platinum and } \\
\text { cetuximab or } \\
\text { anti-EGFR-based therapy } \\
\text { and harboring } \\
\text { homozygous deletion of } \\
\text { CDKN2A, and/or } \\
\text { amplification of CCND1 } \\
\text { and/or CDK6 }\end{array}$ & $\begin{array}{c}\text { Abemaciclib: } \\
400 \mathrm{mg} / \text { day } \\
\text { two doses of } 200 \mathrm{mg} \\
12-\mathrm{h} \text { apart. } \\
\text { For each } 28 \text {-day cycle, a total } \\
\text { of } 56 \text { doses of study drug } \\
\text { will be dispensed }\end{array}$ & $\begin{array}{c}\text { 8-week } \\
\text { non-progression rate } \\
\text { defined as the rate of } \\
\text { patients with } \\
\text { complete response } \\
\text { (CR), partial response } \\
\text { (PR) or stable disease } \\
\text { (SD) lasting at least } \\
8 \text { weeks }\end{array}$ & Ongoing \\
\hline $\begin{array}{l}\text { Interventional, } \\
\text { phase I/ II, } \\
\text { dose } \\
\text { escalation }\end{array}$ & Recruiting & 03024489 & HNSCC & $\begin{array}{l}\text { Albociclib in combined } \\
\text { with cetuximab and } \\
\text { Intensity Modulated } \\
\text { Radiation Therapy (IMRT) } \\
\text { for locally advanced } \\
\text { HNSCC }\end{array}$ & $\begin{array}{c}\text { Palbociclib: } \\
100 \mathrm{mg} \text { oral every day } 3 \\
\text { week-on and 1-week off } \\
\text { during IMRT } \\
\text { Cetuximab: } \\
400 \mathrm{mg} / \mathrm{m} 2 \text { IV at } 7 \text { days } \\
\text { before (day }-7 \text { ) starting } \\
\text { radiation. Then } 250 \mathrm{mg} / \mathrm{m} 2 \\
\text { IV weekly for } 7 \text { weeks. } \\
\text { IMRT: } 5 \text { days on } / 2 \text { days off } \\
\text { with a total dose of } 70 \text { Gy for } \\
\text { 33-35 fractions }\end{array}$ & $\begin{array}{l}\text { Determination of } \\
\text { dose-limiting } \\
\text { toxicities (DLTs) and } \\
\text { recommended phase } \\
\text { II dose (RP2D) }\end{array}$ & Ongoing \\
\hline $\begin{array}{l}\text { Interventional, } \\
\text { open-label, } \\
\text { Phase I, } \\
\text { single arm }\end{array}$ & Recruiting & 03065062 & $\begin{array}{l}\text { Lung cancer } \\
\text { squamous cell, } \\
\text { solid tumors, } \\
\text { HNSCC, } \\
\text { pancreatic } \\
\text { cancer }\end{array}$ & $\begin{array}{l}\text { Palbociclib in combination } \\
\text { with PI3K/mTOR } \\
\text { inhibitor pedatolisib } \\
\text { (PF-05212384) } \\
\text { for patients with } \\
\text { advanced squamous cell } \\
\text { lung, pancreatic, HNSCC } \\
\text { and other solid tumors }\end{array}$ & $\begin{array}{c}\text { Palbociclib: } \\
\text { orally, once daily, } 3 \text { weeks } \\
\text { out of every } 4 \text { in each cycle. } \\
\text { Initial dose for part } 1 \text { of the } \\
\text { study } 100 \mathrm{mg} \text { daily. } \\
\text { Gedatolisib: } \\
\text { once weekly on the first day } \\
\text { for each of the } 4 \text { weeks } \\
\text { during the } 4 \text {-week cycle. } \\
\text { Initial dose for part } 1 \text { of the } \\
\text { study } 110 \mathrm{mg}\end{array}$ & $\begin{array}{c}\text { Maximum Tolerated } \\
\text { Dose and } \\
\text { Recommended Phase } \\
\text { II dose } \\
\text { Incidence of } \\
\text { Treatment-Emergent } \\
\text { Adverse Events (AE) }\end{array}$ & Ongoing \\
\hline $\begin{array}{l}\text { Interventional, } \\
\text { Phase I, } \\
\text { open label, } \\
\text { parallel } \\
\text { assignment }\end{array}$ & Recruiting & 02897375 & $\begin{array}{c}\text { Solid } \\
\text { neoplasms } \\
\text { incl. HNSCC }\end{array}$ & $\begin{array}{l}\text { Palbociclib in combination } \\
\text { with cisplatin or } \\
\text { carboplatin in advanced } \\
\text { solid malignancies }\end{array}$ & $\begin{array}{c}\text { Cisplatin: } \\
\text { IV over 30-60 min on day } 1 \\
\text { Palbociclib: } \\
\text { PO QD on days } 2-22 \text { or: } \\
\text { Carboplatin: } \\
\text { IV over 30-60 min on day } 1 \\
\text { and Palbociclib: } \\
\text { PO QD on days } 2-22\end{array}$ & $\begin{array}{l}\text { Safety and tolerability } \\
\text { of palbociclib when } \\
\text { administered along } \\
\text { with cisplatin or } \\
\text { carboplatin. } \\
\text { Recommended phase } \\
\text { II dose (RP2D) of the } \\
\text { tested combinations }\end{array}$ & Ongoing \\
\hline $\begin{array}{l}\text { Interventional, } \\
\text { phase II, } \\
\text { single } \\
\text { group, open } \\
\text { label }\end{array}$ & Recruiting & 04169074 & HNSCC & $\begin{array}{l}\text { Immune modulation by } \\
\text { abemaciclib } \\
\text { in HPV-negative HNSCC }\end{array}$ & $\begin{array}{l}\text { Abemaciclib: } \\
\text { from days 1-21 in both arms. } \\
\text { May be continued for } \\
\text { additional } 7 \text { days, or up to } \\
28 \text { days, for delays in } \\
\text { planned surgery }\end{array}$ & $\begin{array}{l}\text { Measure quantitative } \\
\text { change in tumor size } \\
\text { to assess the clinical } \\
\text { activity of } \\
\text { abemaciclib }\end{array}$ & Ongoing \\
\hline
\end{tabular}


Table 4. Cont.

\begin{tabular}{|c|c|c|c|c|c|c|c|}
\hline $\begin{array}{l}\text { Study } \\
\text { Type }\end{array}$ & $\begin{array}{l}\text { Study } \\
\text { Status }\end{array}$ & $\begin{array}{l}\text { NCT } \\
\text { Number }\end{array}$ & $\begin{array}{l}\text { Tumor } \\
\text { Entity }\end{array}$ & $\begin{array}{c}\text { Title/ } \\
\text { Intervention }\end{array}$ & $\begin{array}{l}\text { Treatment } \\
\text { Schedule }\end{array}$ & $\begin{array}{l}\text { Primary } \\
\text { Outcome }\end{array}$ & Results \\
\hline $\begin{array}{l}\text { Interventional, } \\
\text { phase I/II, } \\
\text { non- } \\
\text { randomized, } \\
\text { sequential } \\
\text { assignment, } \\
\text { open label }\end{array}$ & $\begin{array}{l}\text { Terminated } \\
\text { (Provider } \\
\text { of drug } \\
\text { decided } \\
\text { to discon- } \\
\text { tinue } \\
\text { study) }\end{array}$ & 03655444 & HNSCC & $\begin{array}{c}\text { Abemaciclib in } \\
\text { combination with } \\
\text { Nivolumab } \\
\text { in Patients with R/M } \\
\text { HNSCC, progressed or } \\
\text { recurred within } 6 \text { months } \\
\text { after platinum-based } \\
\text { chemotherapy }\end{array}$ & $\begin{array}{c}\text { Abemaciclib: } \\
\text { (150 mg) orally twice per day } \\
\text { on Days } 1 \text { through } 28 \text { of } \\
\text { every } 4 \text {-week cycle, } \\
\text { Nivolumab: } \\
480 \text { mg IV over } 30 \text { min } \\
\text { on day } 1 \text { of every } 4 \text {-week } \\
\text { cycle }\end{array}$ & $\begin{array}{c}\text { Determination of } \\
\text { recommended Phase } \\
2 \text { dose of Abemaciclib } \\
\text { combined } \\
\text { with fixed dose of } \\
\text { Nivolumab, Overall } \\
\text { Survival, Best Overall } \\
\text { Tumor Response, } \\
\text { duration of Tumor } \\
\text { Response }\end{array}$ & $\begin{array}{c}\text { Study } \\
\text { terminated, } \\
\mathrm{n}=6, \\
\text { recommended } \\
\text { dose of } \\
\text { Abemaciclib: } \\
150 \text { mg twice a } \\
\text { day, OS } \\
3.7 \text { months }\end{array}$ \\
\hline $\begin{array}{l}\text { Interventional, } \\
\text { phase I, } \\
\text { single group } \\
\text { assignment, } \\
\text { open label }\end{array}$ & $\begin{array}{l}\text { Active, } \\
\text { not } \\
\text { recruiting }\end{array}$ & 04213404 & HNSCC & $\begin{array}{c}\text { Ribociclib in combination } \\
\text { with Spartalizumab } \\
\text { in R/M HNSCC } \\
\text { (RISE-HN) }\end{array}$ & $\begin{array}{c}\text { Ribociclib: } \\
400 \mathrm{mg}, 600 \mathrm{mg} \text {, or } 200 \mathrm{mg} \\
\text { oral daily, day 1-21, } 28 \text { days } \\
\text { a cycle, Spartalizumab: } \\
400 \mathrm{mg} \text { IV on day } 1 \\
28 \text { days a cycle }\end{array}$ & $\begin{array}{c}\text { Progression free } \\
\text { survival, } \\
\text { Overall survival, } \\
\text { Duration of response, } \\
\text { Objective response } \\
\text { rate }\end{array}$ & Ongoing \\
\hline
\end{tabular}

\subsection{Influence of CDKIs on Radiosensitivity}

\subsubsection{CDK4/ 6 Inhibitor Flavopiridol Combined with Radiotherapy}

Flavopirodol is the most extensively studied CDKI among first-generation nonspecific CDKIs. However, it never reached phase III trials and was therefore discontinued in 2012. Despite its rather disappointing success in monotherapy, a surprising sensitization to radiotherapy has been observed.

Data from the literature show that CDKIs from all stages of pharmaceutical development, alter or increase the sensitivity of various tumor types to radiation. Raju et al. demonstrated an in vitro radiosensitizing effect of flavopiridol (300 $\mathrm{nM}$ for 1 day) and the underlying molecular mechanisms in a murine ovarian cancer cell line, OCA-I. After flavopiridol treatment clonogenic assays showed in vitro inhibition of repair from radiation damage after split-dose radiation.

Mechanisms behind that may comprise influencing the expression levels of proteins involved in DNA repair processes and accumulation of cells in G1 and G2 phases with significant reduction of S phase. Among cyclin D1 and cyclin E, flavopiridol downregulated $\mathrm{CDK}$, the catalytic subunit of positive transcription elongation factor $\mathrm{b}(\mathrm{P}-\mathrm{TEFb})$, suggesting that flavopiridol may modulate cellular transcription processes [187].

This modulation of transcription by flavopiridol with a simultaneous radiosensitization effect by reduction in phosphorylation of RNA polymerase II was demonstrated by the same group in human esophageal adenocarcinoma cells and xenograft experiments. Flavopiridol, either given before or after radiation in xenograft experiments with nude mice greatly enhanced the effect of tumor irradiation [188].

Additionally, flavopiridol enhanced radiosensitivity of prostate cancer cell lines. Flavopiridol modified the time course of gammaH2AX expression, a sensitive molecular marker of DNA damage and repair, in irradiated cells. The number of cells expressing gammaH2AX foci was significantly greater in flavopiridol-treated cells. These results indicate that flavopiridol can enhance radiosensitivity of human tumor cells and suggest that this effect may involve an inhibition of DNA repair [189].

\subsubsection{CDK4/6 Inhibitor Palbociclib Combined with Radiotherapy}

Palbociclib was the first specific CDK4/6 inhibitor to be approved in cancer therapy [124]. A recent study in HNSCC by Göttgens et al. demonstrated enhanced radiosensitivity after inhibition of CDK4/6. The clinically approved inhibitor palbociclib exerted radiosensitization effect via decrease of BRCA1 and RAD51 induction, regulators of DNA damage repair, after irradiation. In the presence of palbociclib homologous recombination was diminished and repair of radiation-induced DNA damage was delayed leading to increased chromosomal damage [190]. Furthermore, a combined pharmacological inhibition of MEK and CDK4/ 6 led to substantial synergy in KRAS-mutated NSCLC in vivo [191]. 


\subsubsection{Other CDKIs Combined with Radiotherapy}

Recently, an in vitro study by Tai et al. demonstrated that the selective CDK4/ 6 inhibitor ribociclib, also known as LEE011, induced cell-cycle arrest in the OSCC cell lines SCC4 and SCC25 cells during the G1/M phase through inhibition of Rb phosphorylation. Moreover, the effects of radiation were enhanced in HNSCC cell line OML1 and its radioresistant clone OML1-R. It was easier to overcome radioresistance with additional use of the CDK4/ 6 inhibitor flavopiridol [192]. Jung et al. screened 14,600 compounds for their ability to sensitize tumor cells for radiation. They discovered the small molecule radiosensitizer PPA15. It was found to be a pan-CDKI which, combined with radiation, resulted in suppression of A549 (lung adenocarcinoma) tumor growth in mice by 50-60\% [193].

Kodym et al. investigated the effect of the small peptide SNS-032, a selective CDK2/7/9 inhibitor, on radiosensitivity of NSCLC. This CDKI acts independently of the cell cycle. This provides a tremendous advantage in the treatment of silent, non/low proliferating tumor subpopulations, which are a major cause of radioresistant relapse. Additionally, in non-cyclic cells, a delay in the resolution of radiation-induced gammaH2AX foci, mediated by SNS-032, was detected. These foci are a surrogate for DNA double-strand breaks (DSB), suggesting modulation of DNA DSB repair [194].

Furthermore, inhibition of CDK1, CDK2 and CDK9 in NSCLC by AZD5438 resulted in a dose-dependent increase in radiosensitivity. Notably, the degree of radiosensitization by AZD5438, a new-generation inhibitor, was stronger in radioresistant cell lines. The underlying mechanism is that the small molecule radiosensitizer PPA15 is responsible for inhibition of CDK1, prolonged G2/M phase arrest, inhibition of HR, delayed DNA DSB repair and increased apoptosis. [195].

In HNSCC, modulation of CDK9 expression led to alterations in radiosensitivity. While overexpression of CDK9 mediated radioprotection in five stably CDK9-EGFP-N1 transfected HNSCC cell lines. Depletion of CDK9 by siRNA knockdown clearly enhanced the radiosensitivity of HNSCC cells without an induction of apoptosis [196].

\subsection{Influence of CDKIs on Chemosensitization/Targeted Therapy}

There are also several studies on the effect of combination therapy with CDK4/6 inhibitors in HNSCC. Several studies are currently evaluating palbociclib monotherapy as well as palbociclib treatment in combination with chemotherapy (cisplatin, carboplatin), targeted therapy (cetuximab, gedatolisib), immunotherapy (avelumab) or radiotherapy.

In HNSCC and other tumor entities, it was observed that EGFR-signaling was dominant, but targeted antibody therapy resulted in an extremely low clinical response. In most cases, intrinsic resistance mechanisms and activation of alternative signaling pathways are responsible for this outcome. Several studies have successfully shown a synergistic effect of CDK4/ 6 inhibition when combined with other inhibitors targeting the AKT, MAPK/ERK or mTOR1 pathway in various types of cancer [197-199]. Therefore, combined administration of a CDK4/ 6 inhibitor with chemo- or targeted therapies may be a hopeful treatment against various malignancies.

To show only a few examples: under hypoxia, Palbociclib synergizes with irinotecan, a cytostatic drug for the monotherapy of 5-FU-resistant, advanced, metastatic colon carcinoma, to promote colorectal cancer cell death [200]. Synergy of palbociclib with a MEK inhibitor has also been demonstrated in KRAS mutant colon cancer in vivo $[197,201]$. Vemurafenib-resistant tumors remain sensitive to palbociclib, suggesting that initial treatment with vemurafenib, a selective inhibitor of the oncogene BRAF, followed by palbociclib with or without mTOR inhibitors may be an effective therapeutic approach to manage relapse of vemurafenib-resistant metastatic tumors [202]. In a Phase I-II open-label multicenter study of palbociclib and vemurafenib, patients with unresectable stage III or stage IV BRAF ${ }^{\mathrm{V} 600 \mathrm{MUT}}$ metastatic melanoma were treated with palbociclib once daily for 14 days followed by a 7-day break and continuous dosing of vemurafenib. Here, a significant clinical benefit was achieved in pretreated patients with melanoma [203]. 
The first phase I clinical trial in recurrent and metastatic HNSCC combining palbociclib and cetuximab was performed in 2016. It was found that the combination therapy posed no additional risk to patient safety [139]. A multicenter, multigroup Phase 2 trial with palbociclib and cetuximab in platinum-resistant and in cetuximab-resistant HPV-negative HNSCC was conducted in 2019.

This study reports that palbociclib in combination with cetuximab exhibited substantial antitumor activity in a platinum-resistant group (group 1) and in a cetuximab-resistant group (group 2). The proportion of patients achieving an objective response with palbociclib and cetuximab was 39\% in group 1 and 19\% in group 2 [204]. In the PALATINUS phase II trial among patients with platinum-resistant, HPV-unrelated HNSCC, palbociclib plus cetuximab resulted in a trend of prolongation of median overall survival (OS) compared with cetuximab. The median OS was 9.7 months in the palbociclib arm and 7.8 months in the placebo arm [205].

In tumor xenografts, Robinson et al. reported palbociclib to be highly effective against chemo naive HNSCC cell lines. However, prior cisplatin exposure induced resistance to palbociclib. The reason for this could be an upregulation of c-Myc and cyclin E after cisplatin exposure. Combination treatment with palbociclib and the c-Myc bromodomain inhibitor JQ1 exerted a synergistic anti-growth effect in cisplatin-resistant cells [206]. In HNSCC cell lines, Beck et al. demonstrated that afatinib or lapatinib, both tyrosine kinase inhibitors, combined with palbociclib had promising activity in terms of inhibition of tumor cell viability. However, in this study, the combination was not investigated in in vivo preclinical models [207].

A recent study by Chaudhary et al. demonstrated afatinib and palbociclib in combination decreased the proliferation of HNSCC cells by inducing cell cycle arrest. It was also shown to induce ROS production and senescence [186].

Gadsen et al. found that CDK4/6 inhibitors lead to senescence in HPV-negative HNSCC, but not in HPV-positive HNSCC. The BCL-2 family inhibitor, navitoclax, has been shown to eliminate senescent cells effectively. They also found that combining palbociclib with navitoclax led to decreased HPV-negative HNSCC cell survival and led to increased apoptosis levels in HPV-negative cell lines compared with each agent given alone [208].

In a xenograft mouse model of HNSCC, palbociclib and trametinib, an inhibitor of MEK/ERK pathway, synergistically inhibited tumor growth and enhanced tumor cell apoptosis [209].

Zainal et al. demonstrated that palbociclib resistant OSCC cells harbored PIK3CA mutations and were less responsive to palbociclib compared to wild-type cells. They found out that combination treatment with a PI3K/mTOR inhibitor and palbociclib completely controlled tumor growth in mice [210].

In some cases, inhibition of CDKs has been found to abrogate mechanisms which enable aberrant cells to escape apoptosis. This in turn led to an increase in TNF-related apoptosis-inducing ligand (TRAIL) sensitivity via activation of caspase-8. [211]. Chen et al. demonstrated that the use of flavopiridol led to the upregulation of several $\mathrm{BH} 3-$ only proteins such as BimEL, Noxa, and Bik/NBK. This allowed them to sensitize human myeloma cells to $\mathrm{BH} 3$-mimetic drugs. $\mathrm{BH} 3$ mimetics induce apoptosis by antagonizing the activity of anti-apoptotic Bcl-2 family proteins [212].

In hypopharyngeal carcinoma, CDKI-73, a potent CDK9 inhibitor, was shown to suppress CDK 9 mediated phosphorylation of RNA polymerase II and thus triggered downregulation of Mcl-1 expression. Mcl-1 together with Bcl-2 is, in its full length, an antiapoptotic protein [213]. CDKI-73 was also able to potentiate the induction of apoptosis in combination with cisplatin in hypopharyngeal carcinoma [214].

Additionally, Syn et al. reported a synergistic effect of roniciclib (BAY1000394), a potent pan-CDKI, and cisplatin in preclinical nasopharyngeal carcinoma (NPC) models. They showed that blockage of cell cycle CDK1, CDK2, CDK3, and CDK4 and transcriptional CDK7 and CDK9, resulted in G1/S and G2/M arrest and repression of anti-apoptotic proteins. This effect occurred only in transformed neural progenitor cells but not in non- 
tumorigenic nasopharyngeal epithelial cell line NP69. Moreover, combination of roniciclib and cisplatin in BALB/c xenograft mice led to significantly increased tumor suppression compared to monotherapies [215].

Although experimental data seem promising, there are currently data from one clinical trial in HNSCC combining palbociclib with carboplatin, in which there is no clear benefit from the combination but increase toxicity [216]. However, there is evidence of benefit from those combination in other tumor types, in which the order of administration seems to be critical for CDK4/6 inhibition potentiating the antiproliferative effect of genotoxic therapies [217].

\subsection{Influence of CDKIs on Immunotherapy}

Tumor cell adaption and immune evasion may occur due to a variety of molecular dysregulations. A common mechanism is the alteration of molecules that cause immune evasion by malfunction of the antigen-presenting machinery via class I HLA molecules. Another mechanism to evade the immune system may be the reintroduction of cyclin $\mathrm{D} / \mathrm{CDK} 4$ heterodimers into cell cycle.

Recent research identified that reintroduction of cyclin D/CDK4 in the chromatin assembly complex (CAF), responsible for the reposition of histones $\mathrm{H} 3$ and $\mathrm{H} 4$ at the DNA replication fork, would destabilize PD-L1, a negative regulator of the immune checkpoint PD-1, via the cullin 3-SPOP pathway [218]. The expression of PD-L1 by tumor cells is mainly associated with its immunosuppressive effect. In fact, PD-1/PD-L1 immune checkpoint inhibitors demonstrated remarkable effects in advanced cancer patients, including HNSCC [219-221]. Loss of function mutations of SPOP, on the other hand, increase the level of PD-L1, thereby reducing the presence of tumor-infiltrating lymphocytes in the tumor environment. This has been observed in mouse models. CDK4/6 inhibitors could, theoretically, increase PD-L1 levels, thereby potentiating the immune checkpoint blockade (ICB) treatment [222].

Sensitizing tumor cells to chemotherapy or radiotherapy and simultaneously stimulating the immune system with CDKI is promising to prevent or counteract resistance mechanisms. CDKIs can be extremely helpful in activating specific targets that are important for the development of resistance. Therefore, it is hoped that treatment of patients with CDK inhibitors, especially in combination with immune checkpoint inhibitors, will improve overall response. Figure 19 schematically describes how the mechanism could look like.

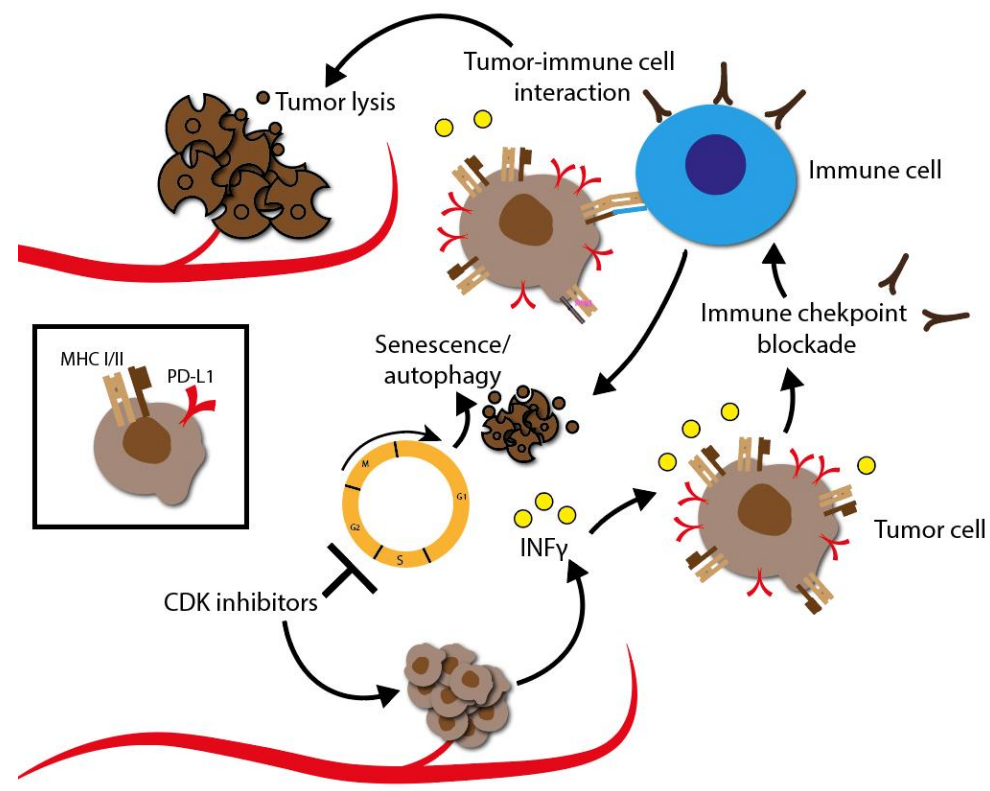

Figure 19. Sensitization to immunotherapy by CDKIs. CDK inhibition prevents cell cycle progression 
and triggers an IFN $\gamma$ response accompanied by MHC I/II upregulation. CDK inhibition also leads to stabilization of PD-L1 membrane expression of tumor cells. The additional use of immune checkpoint inhibitors, such nivolumab and pembrolizumab, blocks the interaction between the inhibitory checkpoint PD-1 and its ligand PD-L1. This prevents resistance to the immune response. As a result, cytotoxic $\mathrm{T}$ cells proliferate, leading to efficient tumor cell killing and clinical response.

Currently, there are five clinical trials investigating the combined efficacy of CDKIs and immunotherapy (NCT03938337, NCT04000529, NCT03498378, NCT03655444, NCT04213404) in HNSCC. Crucial seem the relevant adverse effects, particularly neutropenia as well as rise of liver enzymes, renal disorders and pulmonary toxicity which led to the termination of two studies (NCT03938337, NCT03655444).

\section{Summary and Conclusions}

Considering the tremendous role of CDKs during cell division, it is not surprising that tumor cells have developed a number of strategies to disable or bypass these key components [8]. Cell division is essential for the development and maintenance of a healthy organism.

Each phase transition in the cell cycle is regulated by a specific subset of cyclins and CDKs. CDKs are involved as key regulatory enzymes that sensitively control all cell cycle transitions (Figure 2). The action of CDKs is controlled by specific activation and inactivation by other proteins. Typically, cyclin/CDK complexes are activated by phosphorylation of the CDK-activating kinase. On the contrary, these complexes can be negatively regulated by several cell intrinsic CDKIs. Based on their structural and functional properties, cell intrinsic CDKIs belong to two large families, INK4 and Cip/Kip. The cell intrinsic CDK inhibition mechanism involves interaction between the p16- and CDK6-charged binding domains, resulting in reduced kinase activity and a decreased cyclin-binding surface.

Since cell cycle dysregulation may play a key role in tumor development, many different CDKIs have been developed as anti-cancer drugs.

The early developed CDKIs, like flavopiridol and roscovitine, met only moderate clinical success with partly severe side effects. It was later concluded that the main reason for their failure was the functional diversity of individual CDKs. The use of non-specific CDK pan-inhibitors that addressed several CDKs simultaneously triggered uncontrollable effects which could ultimately cause more harm than good in cancer patients. The focus of further development was therefore on increasing the selectivity of CDKIs. Next generation CDKIs were drugs like dinaciclib and AT7519 as well as small and stapled peptides. Although non-specific pan-CDKIs have shown disappointing clinical results in a broad range of applications, there is nevertheless some evidence that non-specific pan-CDKIs are also actually effective in a limited range of applications. Interestingly, recent studies have shown that combination therapies, in contrast to CDKI monotherapies, can provide promising results in tumor therapy.

Due to their ubiquitous biological functions, many CDKs are of limited use as clinical targets. Because of the narrow therapeutic window, specific CDKIs are necessary to provide a promising treatment with reduced side effects. A variety of clinical studies on specific CDKIs, targeting for example CDK1, CDK2, CDK7, CKD8/19, CDK9 and CDK12/13 are currently in progress. The development of selective inhibitors, of both CDK4 and CDK6, has markedly changed the perception of CDKs as therapeutic targets in cancer. Dual CDK4 and CDK6 inhibitors have been shown to be active in multiple preclinical models, including xenografts, genetically engineered mouse models and primary human tumor explants. The specific CDK4/6 inhibitors albociclib, ribociclib and abemaciclib, are the most studies ones. Unfortunately, approximately $10 \%$ of patients will have primary resistance to CDK4/6 inhibitors.

Although CDKI monotherapy results in partly quite disappointing outcomes, combination therapies appear to have some advantages in tumor therapy. The advantages 
of combining CDKIs together with standard therapies, such as radio-, chemo-, targeted or even immunotherapy, in various tumor types showed a clear tendency towards a synergistic effect of CDKIs, which may ultimately lead to the sensitization of radio- and chemoresistance as well as a sensitization to immune checkpoint blockade. The synergistic effects that contribute overcoming resistance have been observed in several experimental studies and early clinical trials on HNSCC, NSCLC and pancreatic carcinoma, for instance. Especially in tumor entities such as HNSCC, where the 5-year overall survival rate of patients is still around $50 \%$ despite remarkable progress in the last decades, such findings are enormously important. The potential that combination therapies offer, led, with good reason, to a veritable renaissance of CDKIs.

Author Contributions: All authors have read and agreed to the published version of the manuscript.

Funding: There was no funding for this review.

Conflicts of Interest: The authors declare no conflict of interest.

\section{Abbreviations}

\begin{tabular}{|c|c|}
\hline ALL & acute lymphoblastic leukemia \\
\hline AML & acute myeloid leukemia \\
\hline Antp & Drosophila Antennapedia protein \\
\hline $\mathrm{BCL}$ & B cell lymphoma \\
\hline BRCA & Breast Cancer-associated Protein \\
\hline CAF & chromatin assambly complex \\
\hline CAK & CDK-activating kinase \\
\hline CDK & cyclin-dependent kinase \\
\hline CDKI & cyclin-dependent kinase inhibitor \\
\hline Cip/Kip & CDK interacting protein/Kinase inhibitory protein \\
\hline CLL & chronic lymphocytic leukemia \\
\hline $\mathrm{CPP}$ & cell penetrating peptide \\
\hline CR & complete response \\
\hline CRC & colorectal cancer \\
\hline DLT & dose-limiting toxicity \\
\hline DSB & double-strand breaks \\
\hline EGFR & epidermal growth factor receptor \\
\hline EMT & epithelial-mesenchymal transition \\
\hline $\mathrm{HCC}$ & hepatocellular carcinoma \\
\hline HNSCC & head and neck squamous cell carcinoma \\
\hline $\mathrm{HPV}$ & human papillomavirus \\
\hline $\mathrm{IC}_{50}$ & half maximal tolerated dose \\
\hline ICB & immune checkpoint blockade \\
\hline IFN & Interferon \\
\hline LCSC & lung cancer squamous cell \\
\hline M phase & mitosis phase \\
\hline MCL & mantle cell lymphoma \\
\hline MM & multiple myeloma \\
\hline MTD & maximum tolerated dose \\
\hline NHL & non-Hodgkin's lymphoma \\
\hline NPC & nasopharyngeal carcinoma \\
\hline NSCLC & non-small cell lung cancer \\
\hline OS & overall survival \\
\hline OSCC & oral squamous cell carcinoma \\
\hline PDK1 & 3-phosphoinositide-dependent protein kinase 1 \\
\hline PDX & patient derived xenograft \\
\hline PFS & Progression-Free Survival \\
\hline
\end{tabular}




$\begin{array}{ll}\text { ALL } & \text { acute lymphoblastic leukemia } \\ \text { AML } & \text { acute myeloid leukemia } \\ \text { Antp } & \text { Drosophila Antennapedia protein } \\ \text { BCL } & \text { B cell lymphoma } \\ \text { BRCA } & \text { Breast Cancer-associated Protein } \\ \text { CAF } & \text { chromatin assambly complex } \\ \text { CAK } & \text { CDK-activating kinase } \\ \text { CDK } & \text { cyclin-dependent kinase } \\ \text { CDKI } & \text { cyclin-dependent kinase inhibitor } \\ \text { Cip/Kip } & \text { CDK interacting protein/Kinase inhibitory protein } \\ \text { CLL } & \text { chronic lymphocytic leukemia } \\ \text { CPP } & \text { cell penetrating peptide } \\ \text { CR } & \text { complete response } \\ \text { CRC } & \text { colorectal cancer } \\ \text { DLT } & \text { dose-limiting toxicity } \\ \text { DSB } & \text { double-strand breaks } \\ \text { EGFR } & \text { epidermal growth factor receptor } \\ \text { EMT } & \text { epithelial-mesenchymal transition } \\ \text { HCC } & \text { hepatocellular carcinoma } \\ \text { HNSCC } & \text { head and neck squamous cell carcinoma } \\ \text { HPV } & \text { human papillomavirus } \\ \text { IC } 50 & \text { half maximal tolerated dose } \\ \text { ICB } & \text { immune checkpoint blockade } \\ \text { IFN } & \text { Interferon } \\ \text { LCSC } & \text { lung cancer squamous cell } \\ \text { M phase } & \text { mitosis phase } \\ \text { MCL } & \text { mantle cell lymphoma } \\ \text { MM } & \text { multiple myeloma } \\ \text { MTD } & \text { maximum tolerated dose } \\ \text { NHL } & \text { non-Hodgkin's lymphoma } \\ \text { NPC } & \text { nasopharyngeal carcinoma } \\ \text { NSCLC } & \text { non-small cell lung cancer } \\ \text { OS } & \text { overall survival } \\ \text { OSCC } & \text { oral squamous cell carcinoma } \\ \text { PDK1 } & \text { 3-phosphoinositide-dependent protein kinase 1 } \\ \text { PDX } & \text { PFS }\end{array}$

\section{References}

1. Hanahan, D.; Weinberg, R.A. Hallmarks of Cancer: The next Generation. Cell 2011, 144, 646-674. [CrossRef] [PubMed]

2. Sánchez-Martínez, C.; Lallena, M.J.; Sanfeliciano, S.G.; de Dios, A. Cyclin Dependent Kinase (CDK) Inhibitors as Anticancer Drugs: Recent Advances (2015-2019). Bioorg. Med. Chem. Lett. 2019, 29, 126637. [CrossRef] [PubMed]

3. Santuray, R.T.; Johnson, D.E.; Grandis, J.R. New Therapies in Head and Neck Cancer. Trends Cancer 2018, 4, 385-396. [CrossRef]

4. Nurse, P.M. Nobel Lecture. Cyclin Dependent Kinases and Cell Cycle Control. Biosci. Rep. 2002, 22, 487-499. [CrossRef]

5. Drapkin, R.; Le Roy, G.; Cho, H.; Akoulitchev, S.; Reinberg, D. Human Cyclin-Dependent Kinase-Activating Kinase Exists in Three Distinct Complexes. Proc. Natl. Acad. Sci. USA 1996, 93, 6488-6493. [CrossRef] [PubMed]

6. Bregman, D.B.; Pestell, R.G.; Kidd, V.J. Cell Cycle Regulation and RNA Polymerase II. Front. Biosci. J. Virtual Libr. 2000, 5, D244-D257. [CrossRef]

7. Nemet, J.; Jelicic, B.; Rubelj, I.; Sopta, M. The Two Faces of Cdk8, a Positive/Negative Regulator of Transcription. Biochimie 2014, 97, 22-27. [CrossRef]

8. $\quad$ Rodgers, J.T.; King, K.Y.; Brett, J.O.; Cromie, M.J.; Charville, G.W.; Maguire, K.K.; Brunson, C.; Mastey, N.; Liu, L.; Tsai, C.-R.; et al. MTORC1 Controls the Adaptive Transition of Quiescent Stem Cells from G0 to G(Alert). Nature 2014, 510, 393-396. [CrossRef]

9. Malumbres, M.; Barbacid, M. Mammalian Cyclin-Dependent Kinases. Trends Biochem. Sci. 2005, 30, 630-641. [CrossRef]

10. Weinberg, R.A. The Retinoblastoma Protein and Cell Cycle Control. Cell 1995, 81, 323-330. [CrossRef]

11. Pucci, B.; Giordano, A. Cell Cycle and Cancer. Clin. Ter. 1999, 150, 135-141. [PubMed]

12. Sherr, C.J.; Roberts, J.M. Inhibitors of Mammalian G1 Cyclin-Dependent Kinases. Genes Dev. 1995, 9, 1149-1163. [CrossRef] [PubMed] 
13. Galbraith, M.D.; Bender, H.; Espinosa, J.M. Therapeutic Targeting of Transcriptional Cyclin-Dependent Kinases. Transcription 2019, 10, 118-136. [CrossRef]

14. Parua, P.K.; Fisher, R.P. Dissecting the Pol II Transcription Cycle and Derailing Cancer with CDK Inhibitors. Nat. Chem. Biol. 2020, 16, 716-724. [CrossRef]

15. Serrano, M.; Hannon, G.J.; Beach, D. A New Regulatory Motif in Cell-Cycle Control Causing Specific Inhibition of Cyclin D/CDK4. Nature 1993, 366, 704-707. [CrossRef]

16. Hannon, G.J.; Beach, D. P15INK4B Is a Potential Effector of TGF-Beta-Induced Cell Cycle Arrest. Nature 1994, 371, 257-261. [CrossRef] [PubMed]

17. Kamb, A.; Gruis, N.A.; Weaver-Feldhaus, J.; Liu, Q.; Harshman, K.; Tavtigian, S.V.; Stockert, E.; Day, R.S.; Johnson, B.E.; Skolnick, M.H. A Cell Cycle Regulator Potentially Involved in Genesis of Many Tumor Types. Science 1994, 264, 436-440. [CrossRef]

18. Nobori, T.; Miura, K.; Wu, D.J.; Lois, A.; Takabayashi, K.; Carson, D.A. Deletions of the Cyclin-Dependent Kinase-4 Inhibitor Gene in Multiple Human Cancers. Nature 1994, 368, 753-756. [CrossRef] [PubMed]

19. Harper, J.W.; Adami, G.R.; Wei, N.; Keyomarsi, K.; Elledge, S.J. The P21 Cdk-Interacting Protein Cip1 Is a Potent Inhibitor of G1 Cyclin-Dependent Kinases. Cell 1993, 75, 805-816. [CrossRef]

20. Polyak, K.; Kato, J.Y.; Solomon, M.J.; Sherr, C.J.; Massague, J.; Roberts, J.M.; Koff, A. P27Kip1, a Cyclin-Cdk Inhibitor, Links Transforming Growth Factor-Beta and Contact Inhibition to Cell Cycle Arrest. Genes Dev. 1994, 8, 9-22. [CrossRef]

21. Toyoshima, H.; Hunter, T. P27, a Novel Inhibitor of G1 Cyclin-Cdk Protein Kinase Activity, Is Related to P21. Cell 1994, 78, 67-74. [CrossRef]

22. Cheng, M.; Olivier, P.; Diehl, J.A.; Fero, M.; Roussel, M.F.; Roberts, J.M.; Sherr, C.J. The P21(Cip1) and P27(Kip1) CDK "inhibitors" Are Essential Activators of Cyclin D-Dependent Kinases in Murine Fibroblasts. EMBO J. 1999, 18, 1571-1583. [CrossRef] [PubMed]

23. Denicourt, C.; Dowdy, S.F. Cip/Kip Proteins: More than Just CDKs Inhibitors. Genes Dev. 2004, 18, 851-855. [CrossRef] [PubMed]

24. Jin, X.; Nguyen, D.; Zhang, W.W.; Kyritsis, A.P.; Roth, J.A. Cell Cycle Arrest and Inhibition of Tumor Cell Proliferation by the P16INK4 Gene Mediated by an Adenovirus Vector. Cancer Res. 1995, 55, 3250-3253. [PubMed]

25. Chintala, S.K.; Fueyo, J.; Gomez-Manzano, C.; Venkaiah, B.; Bjerkvig, R.; Yung, W.K.; Sawaya, R.; Kyritsis, A.P.; Rao, J.S. Adenovirus-Mediated P16/CDKN2 Gene Transfer Suppresses Glioma Invasion in Vitro. Oncogene 1997, 15, 2049-2057. [CrossRef] [PubMed]

26. Sandig, V.; Brand, K.; Herwig, S.; Lukas, J.; Bartek, J.; Strauss, M. Adenovirally Transferred P16INK4/CDKN2 and P53 Genes Cooperate to Induce Apoptotic Tumor Cell Death. Nat. Med. 1997, 3, 313-319. [CrossRef]

27. Craig, C.; Wersto, R.; Kim, M.; Ohri, E.; Li, Z.; Katayose, D.; Lee, S.J.; Trepel, J.; Cowan, K.; Seth, P. A Recombinant Adenovirus Expressing P27Kip1 Induces Cell Cycle Arrest and Loss of Cyclin-Cdk Activity in Human Breast Cancer Cells. Oncogene 1997, 14, 2283-2289. [CrossRef]

28. Eastham, J.A.; Hall, S.J.; Sehgal, I.; Wang, J.; Timme, T.L.; Yang, G.; Connell-Crowley, L.; Elledge, S.J.; Zhang, W.W.; Harper, J.W. In Vivo Gene Therapy with P53 or P21 Adenovirus for Prostate Cancer. Cancer Res. 1995, 55, 5151-5155.

29. Katayose, Y.; Kim, M.; Rakkar, A.N.; Li, Z.; Cowan, K.H.; Seth, P. Promoting Apoptosis: A Novel Activity Associated with the Cyclin-Dependent Kinase Inhibitor P27. Cancer Res. 1997, 57, 5441-5445.

30. Wang, X.; Gorospe, M.; Huang, Y.; Holbrook, N.J. P27Kip1 Overexpression Causes Apoptotic Death of Mammalian Cells. Oncogene 1997, 15, 2991-2997. [CrossRef]

31. Bonfanti, M.; Taverna, S.; Salmona, M.; D'Incalci, M.; Broggini, M. P21WAF1-Derived Peptides Linked to an Internalization Peptide Inhibit Human Cancer Cell Growth. Cancer Res. 1997, 57, 1442-1446.

32. Luo, Y.; Hurwitz, J.; Massagué, J. Cell-Cycle Inhibition by Independent CDK and PCNA Binding Domains in P21Cip1. Nature 1995, 375, 159-161. [CrossRef]

33. Cirillo, D.; Pentimalli, F.; Giordano, A. Peptides or Small Molecules? Different Approaches to Develop More Effective CDK Inhibitors. Curr. Med. Chem. 2011, 18, 2854-2866. [CrossRef] [PubMed]

34. Talmadge, J.E. Pharmacodynamic Aspects of Peptide Administration Biological Response Modifiers. Adv. Drug Deliv. Rev. 1998, 33, 241-252. [CrossRef]

35. Moiola, M.; Memeo, M.G.; Quadrelli, P. Stapled Peptides-A Useful Improvement for Peptide-Based Drugs. Molecules 2019, 24, 3654. [CrossRef] [PubMed]

36. Verdine, G.L.; Hilinski, G.J. Stapled Peptides for Intracellular Drug Targets. Methods Enzymol. 2012, 503, 3-33. [CrossRef] [PubMed]

37. Chu, Q.; Moellering, R.E.; Hilinski, G.J.; Kim, Y.-W.; Grossmann, T.N.; Yeh, J.T.-H.; Verdine, G.L. Towards Understanding Cell Penetration by Stapled Peptides. MedChem Comm 2015, 6, 111-119. [CrossRef]

38. Walensky, L.D.; Bird, G.H. Hydrocarbon-Stapled Peptides: Principles, Practice, and Progress. J. Med. Chem. 2014, 57, 6275-6288. [CrossRef] [PubMed]

39. Azzarito, V.; Long, K.; Murphy, N.S.; Wilson, A.J. Inhibition of $\alpha$-Helix-Mediated Protein-Protein Interactions Using Designed Molecules. Nat. Chem. 2013, 5, 161-173. [CrossRef] [PubMed]

40. Bouclier, C.; Simon, M.; Laconde, G.; Pellerano, M.; Diot, S.; Lantuejoul, S.; Busser, B.; Vanwonterghem, L.; Vollaire, J.; Josserand, V.; et al. Stapled Peptide Targeting the CDK4/Cyclin D Interface Combined with Abemaciclib Inhibits KRAS Mutant Lung Cancer Growth. Theranostics 2020, 10, 2008-2028. [CrossRef] 
41. Meric-Bernstam, F.; Saleh, M.N.; Infante, J.R.; Goel, S.; Falchook, G.S.; Shapiro, G.; Chung, K.Y.; Conry, R.M.; Hong, D.S.; Wang, J.S.-Z.; et al. Phase I Trial of a Novel Stapled Peptide ALRN-6924 Disrupting MDMX- and MDM2-Mediated Inhibition of WT P53 in Patients with Solid Tumors and Lymphomas. J. Clin. Oncol. 2017, 35, 2505. [CrossRef]

42. Luis, A.C.; Neriah, D.B.; Senecal, A.; Benard, L.; Thiruthuvanathan, V.; Yatsenko, T.; Narayanagari, S.-R.; Wheat, J.C.; Todorova, T.I.; Mitchell, K.; et al. Dual Inhibition of MDMX and MDM2 as a Therapeutic Strategy in Leukemia. Sci. Transl. Med. 2018, 10, eaao3003. [CrossRef]

43. Dickson, M.A. Molecular Pathways: CDK4 Inhibitors for Cancer Therapy. Clin. Cancer Res. 2014, 20, 3379-3383. [CrossRef] [PubMed]

44. VanArsdale, T.; Boshoff, C.; Arndt, K.T.; Abraham, R.T. Molecular Pathways: Targeting the Cyclin D-CDK4/6 Axis for Cancer Treatment. Clin. Cancer Res. 2015, 21, 2905-2910. [CrossRef]

45. Gelbert, L.M.; Cai, S.; Lin, X.; Sanchez-Martinez, C.; del Prado, M.; Lallena, M.J.; Torres, R.; Ajamie, R.T.; Wishart, G.N.; Flack, R.S.; et al. Preclinical Characterization of the CDK4/6 Inhibitor LY2835219: In-Vivo Cell Cycle-Dependent/Independent Anti-Tumor Activities Alone/in Combination with Gemcitabine. Investig. New Drugs 2014, 32, 825-837. [CrossRef]

46. Toure, M.; Crews, C.M. Small-Molecule PROTACS: New Approaches to Protein Degradation. Angew. Chem. Int. Ed. 2016, 55, 1966-1973. [CrossRef] [PubMed]

47. Burslem, G.M.; Smith, B.E.; Lai, A.C.; Jaime-Figueroa, S.; McQuaid, D.C.; Bondeson, D.P.; Toure, M.; Dong, H.; Qian, Y.; Wang, J.; et al. The Advantages of Targeted Protein Degradation Over Inhibition: An RTK Case Study. Cell Chem. Biol. 2018, 25, 67-77.e3. [CrossRef]

48. Wei, M.; Zhao, R.; Cao, Y.; Wei, Y.; Li, M.; Dong, Z.; Liu, Y.; Ruan, H.; Li, Y.; Cao, S.; et al. First Orally Bioavailable Prodrug of Proteolysis Targeting Chimera (PROTAC) Degrades Cyclin-Dependent Kinases 2/4/6 in Vivo. Eur. J. Med. Chem. 2021, 209, 112903. [CrossRef]

49. Zhao, B.; Burgess, K. PROTACs Suppression of CDK4/6, Crucial Kinases for Cell Cycle Regulation in Cancer. Chem. Commun. 2019, 55, 2704-2707. [CrossRef]

50. Brand, M.; Jiang, B.; Bauer, S.; Donovan, K.A.; Liang, Y.; Wang, E.S.; Nowak, R.P.; Yuan, J.C.; Zhang, T.; Kwiatkowski, N.; et al. Homolog-Selective Degradation as a Strategy to Probe the Function of CDK6 in AML. Cell Chem. Biol. 2019, 26, 300-306.e9. [CrossRef]

51. Rana, S.; Bendjennat, M.; Kour, S.; King, H.M.; Kizhake, S.; Zahid, M.; Natarajan, A. Selective Degradation of CDK6 by a Palbociclib Based PROTAC. Bioorg. Med. Chem. Lett. 2019, 29, 1375-1379. [CrossRef] [PubMed]

52. Su, S.; Yang, Z.; Gao, H.; Yang, H.; Zhu, S.; An, Z.; Wang, J.; Li, Q.; Chandarlapaty, S.; Deng, H.; et al. Potent and Preferential Degradation of CDK6 via Proteolysis Targeting Chimera Degraders. J. Med. Chem. 2019, 62, 7575-7582. [CrossRef] [PubMed]

53. De Dominici, M.; Porazzi, P.; Xiao, Y.; Chao, A.; Tang, H.-Y.; Kumar, G.; Fortina, P.; Spinelli, O.; Rambaldi, A.; Peterson, L.F.; et al. Selective Inhibition of Ph-Positive ALL Cell Growth through Kinase-Dependent and -Independent Effects by CDK6-Specific PROTACs. Blood 2020, 135, 1560-1573. [CrossRef]

54. Steinebach, C.; Ng, Y.L.D.; Sosič, I.; Lee, C.-S.; Chen, S.; Lindner, S.; Vu, L.P.; Bricelj, A.; Haschemi, R.; Monschke, M.; et al. Systematic Exploration of Different E3 Ubiquitin Ligases: An Approach towards Potent and Selective CDK6 Degraders. Chem. Sci. 2020, 11, 3474-3486. [CrossRef] [PubMed]

55. Hatcher, J.M.; Wang, E.S.; Johannessen, L.; Kwiatkowski, N.; Sim, T.; Gray, N.S. Development of Highly Potent and Selective Steroidal Inhibitors and Degraders of CDK8. ACS Med. Chem. Lett. 2018, 9, 540-545. [CrossRef]

56. Robb, C.M.; Contreras, J.I.; Kour, S.; Taylor, M.A.; Abid, M.; Sonawane, Y.A.; Zahid, M.; Murry, D.J.; Natarajan, A.; Rana, S Chemically Induced Degradation of CDK9 by a Proteolysis Targeting Chimera (PROTAC). Chem. Commun. 2017, 53, 7577-7580. [CrossRef]

57. Bian, J.; Ren, J.; Li, Y.; Wang, J.; Xu, X.; Feng, Y.; Tang, H.; Wang, Y.; Li, Z. Discovery of Wogonin-Based PROTACs against CDK9 and Capable of Achieving Antitumor Activity. Bioorg. Chem. 2018, 81, 373-381. [CrossRef]

58. Qiu, X.; Li, Y.; Yu, B.; Ren, J.; Huang, H.; Wang, M.; Ding, H.; Li, Z.; Wang, J.; Bian, J. Discovery of Selective CDK9 Degraders with Enhancing Antiproliferative Activity through PROTAC Conversion. Eur. J. Med. Chem. 2021, 211, 113091. [CrossRef]

59. Olson, C.M.; Jiang, B.; Erb, M.A.; Liang, Y.; Doctor, Z.M.; Zhang, Z.; Zhang, T.; Kwiatkowski, N.; Boukhali, M.; Green, J.L.; et al. Pharmacological Perturbation of CDK9 Using Selective CDK9 Inhibition or Degradation. Nat. Chem. Biol. 2018, 14, 163-170. [CrossRef]

60. Zhou, F.; Chen, L.; Cao, C.; Yu, J.; Luo, X.; Zhou, P.; Zhao, L.; Du, W.; Cheng, J.; Xie, Y.; et al. Development of Selective Mono or Dual PROTAC Degrader Probe of CDK Isoforms. Eur. J. Med. Chem. 2020, 187, 111952. [CrossRef]

61. Meijer, L.; Borgne, A.; Mulner, O.; Chong, J.P.; Blow, J.J.; Inagaki, N.; Inagaki, M.; Delcros, J.G.; Moulinoux, J.P. Biochemical and Cellular Effects of Roscovitine, a Potent and Selective Inhibitor of the Cyclin-Dependent Kinases Cdc2, Cdk2 and Cdk5. Eur. J. Biochem. 1997, 243, 527-536. [CrossRef]

62. Whittaker, S.R.; Te Poele, R.H.; Chan, F.; Linardopoulos, S.; Walton, M.I.; Garrett, M.D.; Workman, P. The Cyclin-Dependent Kinase Inhibitor Seliciclib (R-Roscovitine; CYC202) Decreases the Expression of Mitotic Control Genes and Prevents Entry into Mitosis. Cell Cycle 2007, 6, 3114-3131. [CrossRef]

63. Shapiro, G.I. Cyclin-Dependent Kinase Pathways as Targets for Cancer Treatment. J. Clin. Oncol. 2006, 24, 1770-1783. [CrossRef]

64. Sedlacek, H.H. Mechanisms of Action of Flavopiridol. Crit. Rev. Oncol. Hematol. 2001, 38, 139-170. [CrossRef] 
65. Sedlacek, H.; Czech, J.; Naik, R.; Kaur, G.; Worland, P.; Losiewicz, M.; Parker, B.; Carlson, B.; Smith, A.; Senderowicz, A.; et al Flavopiridol (L86 8275; NSC 649890), a New Kinase Inhibitor for Tumor Therapy. Int. J. Oncol. 1996, 9, 1143-1168. [CrossRef]

66. Bose, P.; Simmons, G.L.; Grant, S. Cyclin-Dependent Kinase Inhibitor Therapy for Hematologic Malignancies. Expert Opin. Investig. Drugs 2013, 22, 723-738. [CrossRef]

67. Byrd, J.C.; Lin, T.S.; Dalton, J.T.; Wu, D.; Phelps, M.A.; Fischer, B.; Moran, M.; Blum, K.A.; Rovin, B.; Brooker-McEldowney, M.; et al. Flavopiridol Administered Using a Pharmacologically Derived Schedule Is Associated with Marked Clinical Efficacy in Refractory, Genetically High-Risk Chronic Lymphocytic Leukemia. Blood 2007, 109, 399-404. [CrossRef]

68. Kouroukis, C.T.; Belch, A.; Crump, M.; Eisenhauer, E.; Gascoyne, R.D.; Meyer, R.; Lohmann, R.; Lopez, P.; Powers, J.; Turner, R.; et al. Flavopiridol in Untreated or Relapsed Mantle-Cell Lymphoma: Results of a Phase II Study of the National Cancer Institute of Canada Clinical Trials Group. J. Clin. Oncol. 2003, 21, 1740-1745. [CrossRef]

69. Lin, T.S.; Blum, K.A.; Fischer, D.B.; Mitchell, S.M.; Ruppert, A.S.; Porcu, P.; Kraut, E.H.; Baiocchi, R.A.; Moran, M.E.; Johnson, A.J.; et al. Flavopiridol, Fludarabine, and Rituximab in Mantle Cell Lymphoma and Indolent B-Cell Lymphoproliferative Disorders. J. Clin. Oncol. 2010, 28, 418-423. [CrossRef]

70. Raynaud, F.I.; Whittaker, S.R.; Fischer, P.M.; McClue, S.; Walton, M.I.; Barrie, S.E.; Garrett, M.D.; Rogers, P.; Clarke, S.J.; Kelland, L.R.; et al. In Vitro and in Vivo Pharmacokinetic-Pharmacodynamic Relationships for the Trisubstituted Aminopurine Cyclin-Dependent Kinase Inhibitors Olomoucine, Bohemine and CYC202. Clin. Cancer Res. 2005, 11, 4875-4887. [CrossRef]

71. Benson, C.; White, J.; Bono, J.D.; O’Donnell, A.; Raynaud, F.; Cruickshank, C.; McGrath, H.; Walton, M.; Workman, P.; Kaye, S.; et al. A Phase I Trial of the Selective Oral Cyclin-Dependent Kinase Inhibitor Seliciclib (CYC202; R-Roscovitine), Administered Twice Daily for 7 Days Every 21 Days. Br. J. Cancer 2007, 96, 29-37. [CrossRef] [PubMed]

72. Le Tourneau, C.; Faivre, S.; Laurence, V.; Delbaldo, C.; Vera, K.; Girre, V.; Chiao, J.; Armour, S.; Frame, S.; Green, S.R.; et al Phase I Evaluation of Seliciclib (R-Roscovitine), a Novel Oral Cyclin-Dependent Kinase Inhibitor, in Patients with Advanced Malignancies. Eur. J. Cancer 2010, 46, 3243-3250. [CrossRef]

73. University Hospital. Brest A Phase II, Dose Ranging, Multicenter, Double-Blind, Placebo Controlled Study to Evaluate Safety and Effects of (R)-Roscovitine in Adults Subjects with Cystic Fibrosis, Carrying 2 Cystic Fibrosis Causing Mutations with at Least One F508del-CFTR Mutation and Chronically Infected with Pseudomonas aeruginosa, a Study Involving 36 CF Patients (24 Treated, 12 Controls). ROSCO-CF. 2018. Available online: https: / / clinicaltrials.gov/ (accessed on 1 December 2021).

74. Parry, D.; Guzi, T.; Shanahan, F.; Davis, N.; Prabhavalkar, D.; Wiswell, D.; Seghezzi, W.; Paruch, K.; Dwyer, M.P.; Doll, R.; et al Dinaciclib (SCH 727965), a Novel and Potent Cyclin-Dependent Kinase Inhibitor. Mol. Cancer Ther. 2010, 9, 2344-2353. [CrossRef]

75. Chen, Z.; Wang, Z.; Pang, J.C.; Yu, Y.; Bieerkehazhi, S.; Lu, J.; Hu, T.; Zhao, Y.; Xu, X.; Zhang, H.; et al. Multiple CDK Inhibitor Dinaciclib Suppresses Neuroblastoma Growth via Inhibiting CDK2 and CDK9 Activity. Sci. Rep. 2016, 6, 29090. [CrossRef] [PubMed]

76. Nemunaitis, J.J.; Small, K.A.; Kirschmeier, P.; Zhang, D.; Zhu, Y.; Jou, Y.-M.; Statkevich, P.; Yao, S.-L.; Bannerji, R. A First-in-Human, Phase 1, Dose-Escalation Study of Dinaciclib, a Novel Cyclin-Dependent Kinase Inhibitor, Administered Weekly in Subjects with Advanced Malignancies. J. Transl. Med. 2013, 11, 259. [CrossRef] [PubMed]

77. Mita, M.M.; Joy, A.A.; Mita, A.; Sankhala, K.; Jou, Y.-M.; Zhang, D.; Statkevich, P.; Zhu, Y.; Yao, S.-L.; Small, K.; et al. Randomized Phase II Trial of the Cyclin-Dependent Kinase Inhibitor Dinaciclib (MK-7965) versus Capecitabine in Patients with Advanced Breast Cancer. Clin. Breast Cancer 2014, 14, 169-176. [CrossRef]

78. Stephenson, J.J.; Nemunaitis, J.; Joy, A.A.; Martin, J.C.; Jou, Y.-M.; Zhang, D.; Statkevich, P.; Yao, S.-L.; Zhu, Y.; Zhou, H.; et al. Randomized Phase 2 Study of the Cyclin-Dependent Kinase Inhibitor Dinaciclib (MK-7965) versus Erlotinib in Patients with Non-Small Cell Lung Cancer. Lung Cancer 2014, 83, 219-223. [CrossRef]

79. Gojo, I.; Walker, A.; Cooper, M.; Feldman, E.J.; Padmanabhan, S.; Baer, M.R.; Poon, J.; Small, K.; Zhang, D.; Sadowska, M.; et al. Phase II Study of the Cyclin-Dependent Kinase (CDK) Inhibitor Dinaciclib (SCH 727965) in Patients with Advanced Acute Leukemias. Blood 2010, 116, 3287. [CrossRef]

80. Kumar, S.K.; LaPlant, B.; Chng, W.J.; Zonder, J.; Callander, N.; Fonseca, R.; Fruth, B.; Roy, V.; Erlichman, C.; Stewart, A.K.; et al. Dinaciclib, a Novel CDK Inhibitor, Demonstrates Encouraging Single-Agent Activity in Patients with Relapsed Multiple Myeloma. Blood 2015, 125, 443-448. [CrossRef]

81. Ghia, P.; Scarfò, L.; Perez, S.; Pathiraja, K.; Derosier, M.; Small, K.; McCrary Sisk, C.; Patton, N. Efficacy and Safety of Dinaciclib vs. Ofatumumab in Patients with Relapsed/Refractory Chronic Lymphocytic Leukemia. Blood 2017, 129, 1876-1878. [CrossRef]

82. Squires, M.S.; Cooke, L.; Lock, V.; Qi, W.; Lewis, E.J.; Thompson, N.T.; Lyons, J.F.; Mahadevan, D. AT7519, a Cyclin-Dependent Kinase Inhibitor, Exerts Its Effects by Transcriptional Inhibition in Leukemia Cell Lines and Patient Samples. Mol. Cancer Ther. 2010, 9, 920-928. [CrossRef] [PubMed]

83. Chen, P.; Lee, N.V.; Hu, W.; Xu, M.; Ferre, R.A.; Lam, H.; Bergqvist, S.; Solowiej, J.; Diehl, W.; He, Y.-A.; et al. Spectrum and Degree of CDK Drug Interactions Predicts Clinical Performance. Mol. Cancer Ther. 2016, 15, 2273-2281. [CrossRef] [PubMed]

84. Xiao, Z.; Hao, Y.; Liu, B.; Qian, L. Indirubin and Meisoindigo in the Treatment of Chronic Myelogenous Leukemia in China. Leuk. Lymphoma 2002, 43, 1763-1768. [CrossRef]

85. Zhang, Z.N.; Liu, E.K.; Zheng, T.L.; Li, D.G. Treatment of Chronic Myelocytic Leukemia (CML) by Traditional Chinese Medicine and Western Medicine Alternately. J. Tradit. Chin. Med. 1985, 5, 246-248.

86. Kim, W.-H.; Jeong, P.; Kim, S.-W.; Cho, H.; Lee, J.-M.; Seo, S.; Shen, H.; Ahn, Y.; Jung, D.-W.; Kim, Y.-C.; et al. A Novel Indirubin Derivative That Increases Somatic Cell Plasticity and Inhibits Tumorigenicity. Bioorg. Med. Chem. 2019, 27, 2923-2934. [CrossRef] 
87. Yan, L.; Lai, F.; Chen, X.; Xiao, Z. Discovery of Novel Indirubin-3'-Monoxime Derivatives as Potent Inhibitors against CDK2 and CDK9. Bioorg. Med. Chem. Lett. 2015, 25, 2447-2451. [CrossRef] [PubMed]

88. Hoessel, R.; Leclerc, S.; Endicott, J.A.; Nobel, M.E.; Lawrie, A.; Tunnah, P.; Leost, M.; Damiens, E.; Marie, D.; Marko, D.; et al Indirubin, the Active Constituent of a Chinese Antileukaemia Medicine, Inhibits Cyclin-Dependent Kinases. Nat. Cell Biol. 1999, 1, 60-67. [CrossRef] [PubMed]

89. Davies, T.G.; Tunnah, P.; Meijer, L.; Marko, D.; Eisenbrand, G.; Endicott, J.A.; Noble, M.E. Inhibitor Binding to Active and Inactive CDK2: The Crystal Structure of CDK2-Cyclin A/Indirubin-5-Sulphonate. Structure 2001, 9, 389-397. [CrossRef]

90. Basati, G.; Saffari-Chaleshtori, J.; Abbaszadeh, S.; Asadi-Samani, M.; Ashrafi-Dehkordi, K. Molecular Dynamics Mechanisms of the Inhibitory Effects of Abemaciclib, Hymenialdisine, and Indirubin on CDK-6. Curr. Drug Res. Rev. 2019, 11, 135-141. [CrossRef]

91. Senderowicz, A.M.; Sausville, E.A. Preclinical and Clinical Development of Cyclin-Dependent Kinase Modulators. JNCI J. Natl. Cancer Inst. 2000, 92, 376-387. [CrossRef]

92. Abdelgalil, A.A.; Alkahtani, H.M.; Al-Jenoobi, F.I. Sorafenib. Profiles Drug Subst. Excip. Relat. Methodol. 2019, 44, 239-266. [CrossRef]

93. Wu, C.X.; Wang, X.Q.; Chok, S.H.; Man, K.; Tsang, S.H.Y.; Chan, A.C.Y.; Ma, K.W.; Xia, W.; Cheung, T.T. Blocking CDK1/PDK1/ $\beta-$ Catenin Signaling by CDK1 Inhibitor RO3306 Increased the Efficacy of Sorafenib Treatment by Targeting Cancer Stem Cells in a Preclinical Model of Hepatocellular Carcinoma. Theranostics 2018, 8, 3737-3750. [CrossRef]

94. Noble, M.E.; Endicott, J.A. Chemical Inhibitors of Cyclin-Dependent Kinases: Insights into Design from X-Ray Crystallographic Studies. Pharmacol. Ther. 1999, 82, 269-278. [CrossRef]

95. Beaver, J.A.; Amiri-Kordestani, L.; Charlab, R.; Chen, W.; Palmby, T.; Tilley, A.; Zirkelbach, J.F.; Yu, J.; Liu, Q.; Zhao, L.; et al. FDA Approval: Palbociclib for the Treatment of Postmenopausal Patients with Estrogen Receptor-Positive, HER2-Negative Metastatic Breast Cancer. Clin. Cancer Res. 2015, 21, 4760-4766. [CrossRef] [PubMed]

96. Van Caloen, G.; Schmitz, S.; van Marcke, C.; Caignet, X.; Mendola, A.; Pyr Dit Ruys, S.; Roger, P.P.; Vertommen, D.; Machiels, J.-P. Preclinical Evaluation of the Association of the Cyclin-Dependent Kinase 4/6 Inhibitor, Ribociclib, and Cetuximab in Squamous Cell Carcinoma of the Head and Neck. Cancers 2021, 13, 1251. [CrossRef]

97. Dickler, M.N.; Tolaney, S.M.; Rugo, H.S.; Cortés, J.; Diéras, V.; Patt, D.; Wildiers, H.; Hudis, C.A.; O'Shaughnessy, J.; Zamora, E.; et al. MONARCH 1, a Phase 2 Study of Abemaciclib, a CDK4 and CDK6 Inhibitor, as a Single Agent, in Patients with Refractory HR+/HER2- Metastatic Breast Cancer. Clin. Cancer Res. 2017, 23, 5218-5224. [CrossRef]

98. Dhillon, S. Trilaciclib: First Approval. Drugs 2021, 81, 867-874. [CrossRef] [PubMed]

99. Long, F.; He, Y.; Fu, H.; Li, Y.; Bao, X.; Wang, Q.; Wang, Y.; Xie, C.; Lou, L. Preclinical Characterization of SHR6390, a Novel CDK 4/6 Inhibitor, in Vitro and in Human Tumor Xenograft Models. Cancer Sci. 2019, 110, 1420-1430. [CrossRef]

100. Bisi, J.E.; Sorrentino, J.A.; Jordan, J.L.; Darr, D.D.; Roberts, P.J.; Tavares, F.X.; Strum, J.C. Preclinical Development of G1T38: A Novel, Potent and Selective Inhibitor of Cyclin Dependent Kinases 4/6 for Use as an Oral Antineoplastic in Patients with CDK4/6 Sensitive Tumors. Oncotarget 2017, 8, 42343-42358. [CrossRef]

101. Xu, B.; Wang, J.; Liu, X.; Fang, J.; Yao, Z.; Wang, J. 344P-A Phase I Study of XZP-3287, a Novel Oral CDK4/6 Inhibitor, Administered on a Continuous Dosing Schedule, in Patients with Advanced Solid Tumours. Ann. Oncol. 2019, 30, v123. [CrossRef]

102. Marineau, J.J.; Hamman, K.B.; Hu, S.; Alnemy, S.; Mihalich, J.; Kabro, A.; Whitmore, K.M.; Winter, D.K.; Roy, S.; Ciblat, S.; et al. Discovery of SY-5609: A Selective, Noncovalent Inhibitor of CDK7. J. Med. Chem. 2021, in press. [CrossRef]

103. Kwiatkowski, N.; Zhang, T.; Rahl, P.B.; Abraham, B.J.; Reddy, J.; Ficarro, S.B.; Dastur, A.; Amzallag, A.; Ramaswamy, S.; Tesar, B.; et al. Targeting Transcription Regulation in Cancer with a Covalent CDK7 Inhibitor. Nature 2014, 511, 616-620. [CrossRef]

104. Cee, V.J.; Chen, D.Y.-K.; Lee, M.R.; Nicolaou, K.C. Cortistatin A Is a High-Affinity Ligand of Protein Kinases ROCK, CDK8, and CDK11. Angew. Chem. Int. Ed. 2009, 48, 8952-8957. [CrossRef] [PubMed]

105. Pelish, H.E.; Liau, B.B.; Nitulescu, I.I.; Tangpeerachaikul, A.; Poss, Z.C.; Da Silva, D.H.; Caruso, B.T.; Arefolov, A.; Fadeyi, O.; Christie, A.L.; et al. Mediator Kinase Inhibition Further Activates Super-Enhancer-Associated Genes in AML. Nature 2015, 526, 273-276. [CrossRef] [PubMed]

106. Dale, T.; Clarke, P.A.; Esdar, C.; Waalboer, D.; Adeniji-Popoola, O.; Ortiz-Ruiz, M.-J.; Mallinger, A.; Samant, R.S.; Czodrowski, P.; Musil, D.; et al. A Selective Chemical Probe for Exploring the Role of CDK8 and CDK19 in Human Disease. Nat. Chem. Biol. 2015, 11, 973-980. [CrossRef] [PubMed]

107. Koehler, M.F.T.; Bergeron, P.; Blackwood, E.M.; Bowman, K.; Clark, K.R.; Firestein, R.; Kiefer, J.R.; Maskos, K.; McCleland, M.L.; Orren, L.; et al. Development of a Potent, Specific CDK8 Kinase Inhibitor Which Phenocopies CDK8/19 Knockout Cells. ACS Med. Chem. Lett. 2016, 7, 223-228. [CrossRef] [PubMed]

108. Mallinger, A.; Schiemann, K.; Rink, C.; Sejberg, J.; Honey, M.A.; Czodrowski, P.; Stubbs, M.; Poeschke, O.; Busch, M.; Schneider, R.; et al. 2,8-Disubstituted-1,6-Naphthyridines and 4,6-Disubstituted-Isoquinolines with Potent, Selective Affinity for CDK8/19. ACS Med. Chem. Lett. 2016, 7, 573-578. [CrossRef] [PubMed]

109. Czodrowski, P.; Mallinger, A.; Wienke, D.; Esdar, C.; Pöschke, O.; Busch, M.; Rohdich, F.; Eccles, S.A.; Ortiz-Ruiz, M.-J.; Schneider, R.; et al. Structure-Based Optimization of Potent, Selective, and Orally Bioavailable CDK8 Inhibitors Discovered by High-Throughput Screening. J. Med. Chem. 2016, 59, 9337-9349. [CrossRef] 
110. Cassandri, M.; Fioravanti, R.; Pomella, S.; Valente, S.; Rotili, D.; Del Baldo, G.; De Angelis, B.; Rota, R.; Mai, A. CDK9 as a Valuable Target in Cancer: From Natural Compounds Inhibitors to Current Treatment in Pediatric Soft Tissue Sarcomas. Front. Pharmacol. 2020, 11, 1230. [CrossRef] [PubMed]

111. Definition of CDK9 Inhibitor GFH009-NCI Drug Dictionary-National Cancer Institute. Available online: https: / www.cancer gov/publications/dictionaries/cancer-drug/def/cdk9-inhibitor-gfh009 (accessed on 28 December 2021).

112. Richters, A.; Doyle, S.K.; Freeman, D.B.; Lee, C.; Leifer, B.S.; Jagannathan, S.; Kabinger, F.; Koren, J.V.; Struntz, N.B.; Urgiles, J.; et al. Modulating Androgen Receptor-Driven Transcription in Prostate Cancer with Selective CDK9 Inhibitors. Cell Chem. Biol. 2021, 28, 134-147.e14. [CrossRef] [PubMed]

113. Frame, S.; Saladino, C.; MacKay, C.; Atrash, B.; Sheldrake, P.; McDonald, E.; Clarke, P.A.; Workman, P.; Blake, D.; Zheleva, D. Fadraciclib (CYC065), a Novel CDK Inhibitor, Targets Key pro-Survival and Oncogenic Pathways in Cancer. PLoS ONE 2020, 15, e0234103. [CrossRef] [PubMed]

114. Zhang, T.; Kwiatkowski, N.; Olson, C.M.; Dixon-Clarke, S.E.; Abraham, B.J.; Greifenberg, A.K.; Ficarro, S.B.; Elkins, J.M.; Liang, Y.; Hannett, N.M.; et al. Covalent Targeting of Remote Cysteine Residues to Develop CDK12 and CDK13 Inhibitors. Nat. Chem. Biol. 2016, 12, 876-884. [CrossRef] [PubMed]

115. Voets, E.; Marsman, J.; Demmers, J.; Beijersbergen, R.; Wolthuis, R. The Lethal Response to Cdk1 Inhibition Depends on Sister Chromatid Alignment Errors Generated by KIF4 and Isoform 1 of PRC1. Sci. Rep. 2015, 5, 14798. [CrossRef]

116. Kang, J.; Sergio, C.M.; Sutherland, R.L.; Musgrove, E.A. Targeting Cyclin-Dependent Kinase 1 (CDK1) but Not CDK4/6 or CDK2 Is Selectively Lethal to MYC-Dependent Human Breast Cancer Cells. BMC Cancer 2014, 14, 32. [CrossRef] [PubMed]

117. Al-Sanea, M.M.; Obaidullah, A.J.; Shaker, M.E.; Chilingaryan, G.; Alanazi, M.M.; Alsaif, N.A.; Alkahtani, H.M.; Alsubaie, S.A.; Abdelgawad, M.A. A New CDK2 Inhibitor with 3-Hydrazonoindolin-2-One Scaffold Endowed with Anti-Breast Cancer Activity: Design, Synthesis, Biological Evaluation, and In Silico Insights. Molecules 2021, 26, 412. [CrossRef]

118. Hamilton, E.; Infante, J.R. Targeting CDK4/6 in Patients with Cancer. Cancer Treat. Rev. 2016, 45, 129-138. [CrossRef] [PubMed]

119. Gelmon, K.; Walshe, J.M.; Mahtani, R.; Joy, A.A.; Karuturi, M.; Neven, P.; Lu, D.R.; Kim, S.; Schnell, P.; Bananis, E.; et al. Efficacy and Safety of Palbociclib in Patients with Estrogen Receptor-Positive/Human Epidermal Growth Factor Receptor 2-Negative Advanced Breast Cancer with Preexisting Conditions: A Post Hoc Analysis of PALOMA-2. Breast 2021, 59, 321-326. [CrossRef]

120. Kalra, S.; Joshi, G.; Munshi, A.; Kumar, R. Structural Insights of Cyclin Dependent Kinases: Implications in Design of Selective Inhibitors. Eur. J. Med. Chem. 2017, 142, 424-458. [CrossRef]

121. VanderWel, S.N.; Harvey, P.J.; McNamara, D.J.; Repine, J.T.; Keller, P.R.; Quin, J.; Booth, R.J.; Elliott, W.L.; Dobrusin, E.M.; Fry, D.W.; et al. Pyrido[2,3-d]Pyrimidin-7-Ones as Specific Inhibitors of Cyclin-Dependent Kinase 4. J. Med. Chem. 2005, 48, 2371-2387. [CrossRef]

122. Xu, H.; Yu, S.; Liu, Q.; Yuan, X.; Mani, S.; Pestell, R.G.; Wu, K. Recent Advances of Highly Selective CDK4/6 Inhibitors in Breast Cancer. J. Hematol. Oncol. 2017, 10, 97. [CrossRef]

123. Finn, R.S.; Dering, J.; Conklin, D.; Kalous, O.; Cohen, D.J.; Desai, A.J.; Ginther, C.; Atefi, M.; Chen, I.; Fowst, C.; et al. PD 0332991, a Selective Cyclin D Kinase 4/6 Inhibitor, Preferentially Inhibits Proliferation of Luminal Estrogen Receptor-Positive Human Breast Cancer Cell Lines in Vitro. Breast Cancer Res. 2009, 11, R77. [CrossRef]

124. Rugo, H.S.; Diéras, V.; Gelmon, K.A.; Finn, R.S.; Slamon, D.J.; Martin, M.; Neven, P.; Shparyk, Y.; Mori, A.; Lu, D.R.; et al. Impact of Palbociclib plus Letrozole on Patient-Reported Health-Related Quality of Life: Results from the PALOMA-2 Trial. Ann. Oncol. 2018, 29, 888-894. [CrossRef]

125. Lu, J. Palbociclib: A First-in-Class CDK4/CDK6 Inhibitor for the Treatment of Hormone-Receptor Positive Advanced Breast Cancer. J. Hematol. Oncol. 2015, 8, 98. [CrossRef]

126. Whiteway, S.L.; Harris, P.S.; Venkataraman, S.; Alimova, I.; Birks, D.K.; Donson, A.M.; Foreman, N.K.; Vibhakar, R. Inhibition of Cyclin-Dependent Kinase 6 Suppresses Cell Proliferation and Enhances Radiation Sensitivity in Medulloblastoma Cells. J. Neurooncol. 2013, 111, 113-121. [CrossRef] [PubMed]

127. Choi, Y.J.; Li, X.; Hydbring, P.; Sanda, T.; Stefano, J.; Christie, A.L.; Signoretti, S.; Look, A.T.; Kung, A.L.; von Boehmer, H.; et al. The Requirement for Cyclin D Function in Tumor Maintenance. Cancer Cell 2012, 22, 438-451. [CrossRef] [PubMed]

128. Rivadeneira, D.B.; Mayhew, C.N.; Thangavel, C.; Sotillo, E.; Reed, C.A.; Graña, X.; Knudsen, E.S. Proliferative Suppression by CDK4/6 Inhibition: Complex Function of the Retinoblastoma Pathway in Liver Tissue and Hepatoma Cells. Gastroenterology 2010, 138, 1920-1930. [CrossRef] [PubMed]

129. Rader, J.; Russell, M.R.; Hart, L.S.; Nakazawa, M.S.; Belcastro, L.T.; Martinez, D.; Li, Y.; Carpenter, E.L.; Attiyeh, E.F.; Diskin, S.J.; et al. Dual CDK4/CDK6 Inhibition Induces Cell-Cycle Arrest and Senescence in Neuroblastoma. Clin. Cancer Res. 2013, 19, 6173-6182. [CrossRef]

130. Logan, J.E.; Mostofizadeh, N.; Desai, A.J.; Von Euw, E.; Conklin, D.; Konkankit, V.; Hamidi, H.; Eckardt, M.; Anderson, L.; Chen, H.-W.; et al. PD-0332991, a Potent and Selective Inhibitor of Cyclin-Dependent Kinase 4/6, Demonstrates Inhibition of Proliferation in Renal Cell Carcinoma at Nanomolar Concentrations and Molecular Markers Predict for Sensitivity. Anticancer Res. 2013, 33, 2997-3004.

131. Baughn, L.B.; Di Liberto, M.; Wu, K.; Toogood, P.L.; Louie, T.; Gottschalk, R.; Niesvizky, R.; Cho, H.; Ely, S.; Moore, M.A.S.; et al. A Novel Orally Active Small Molecule Potently Induces G1 Arrest in Primary Myeloma Cells and Prevents Tumor Growth by Specific Inhibition of Cyclin-Dependent Kinase 4/6. Cancer Res. 2006, 66, 7661-7667. [CrossRef] [PubMed] 
132. Marzec, M.; Kasprzycka, M.; Lai, R.; Gladden, A.B.; Wlodarski, P.; Tomczak, E.; Nowell, P.; Deprimo, S.E.; Sadis, S.; Eck, S.; et al. Mantle Cell Lymphoma Cells Express Predominantly Cyclin D1a Isoform and Are Highly Sensitive to Selective Inhibition of CDK4 Kinase Activity. Blood 2006, 108, 1744-1750. [CrossRef] [PubMed]

133. Liu, F.; Korc, M. Cdk4/6 Inhibition Induces Epithelial-Mesenchymal Transition and Enhances Invasiveness in Pancreatic Cancer Cells. Mol. Cancer Ther. 2012, 11, 2138-2148. [CrossRef] [PubMed]

134. Ismail, A.; Bandla, S.; Reveiller, M.; Toia, L.; Zhou, Z.; Gooding, W.E.; Kalatskaya, I.; Stein, L.; D'Souza, M.; Litle, V.R.; et al. Early $\mathrm{G}_{1}$ Cyclin-Dependent Kinases as Prognostic Markers and Potential Therapeutic Targets in Esophageal Adenocarcinoma. Clin. Cancer Res. 2011, 17, 4513-4522. [CrossRef]

135. Young, R.J.; Waldeck, K.; Martin, C.; Foo, J.H.; Cameron, D.P.; Kirby, L.; Do, H.; Mitchell, C.; Cullinane, C.; Liu, W.; et al. Loss of CDKN2A Expression Is a Frequent Event in Primary Invasive Melanoma and Correlates with Sensitivity to the CDK4/6 Inhibitor PD0332991 in Melanoma Cell Lines. Pigment Cell Melanoma Res. 2014, 27, 590-600. [CrossRef] [PubMed]

136. Puyol, M.; Martín, A.; Dubus, P.; Mulero, F.; Pizcueta, P.; Khan, G.; Guerra, C.; Santamaría, D.; Barbacid, M. A Synthetic Lethal Interaction between K-Ras Oncogenes and Cdk4 Unveils a Therapeutic Strategy for Non-Small Cell Lung Carcinoma. Cancer Cell 2010, 18, 63-73. [CrossRef] [PubMed]

137. Trapé, A.P.; Liu, S.; Cortes, A.C.; Ueno, N.T.; Gonzalez-Angulo, A.M. Effects of CDK4/6 Inhibition in Hormone ReceptorPositive/Human Epidermal Growth Factor Receptor 2-Negative Breast Cancer Cells with Acquired Resistance to Paclitaxel. J. Cancer 2016, 7, 947-956. [CrossRef]

138. Franco, J.; Witkiewicz, A.K.; Knudsen, E.S. CDK4/6 Inhibitors Have Potent Activity in Combination with Pathway Selective Therapeutic Agents in Models of Pancreatic Cancer. Oncotarget 2014, 5, 6512-6525. [CrossRef]

139. Michel, L.; Ley, J.; Wildes, T.M.; Schaffer, A.; Robinson, A.; Chun, S.-E.; Lee, W.; Lewis, J.; Trinkaus, K.; Adkins, D. Phase I Trial of Palbociclib, a Selective Cyclin Dependent Kinase 4/6 Inhibitor, in Combination with Cetuximab in Patients with Recurrent/Metastatic Head and Neck Squamous Cell Carcinoma. Oral Oncol. 2016, 58, 41-48. [CrossRef]

140. Michaud, K.; Solomon, D.A.; Oermann, E.; Kim, J.-S.; Zhong, W.-Z.; Prados, M.D.; Ozawa, T.; James, C.D.; Waldman, T. Pharmacologic Inhibition of Cyclin-Dependent Kinases 4 and 6 Arrests the Growth of Glioblastoma Multiforme Intracranial Xenografts. Cancer Res. 2010, 70, 3228-3238. [CrossRef]

141. Tang, L.H.; Contractor, T.; Clausen, R.; Klimstra, D.S.; Du, Y.-C.N.; Allen, P.J.; Brennan, M.F.; Levine, A.J.; Harris, C.R. Attenuation of the Retinoblastoma Pathway in Pancreatic Neuroendocrine Tumors Due to Increased Cdk4/Cdk6. Clin. Cancer Res. 2012, 18, 4612-4620. [CrossRef]

142. Barton, K.L.; Misuraca, K.; Cordero, F.; Dobrikova, E.; Min, H.D.; Gromeier, M.; Kirsch, D.G.; Becher, O.J. PD-0332991, a CDK4/6 Inhibitor, Significantly Prolongs Survival in a Genetically Engineered Mouse Model of Brainstem Glioma. PLoS ONE 2013, 8, e77639. [CrossRef]

143. Fry, D.W.; Harvey, P.J.; Keller, P.R.; Elliott, W.L.; Meade, M.; Trachet, E.; Albassam, M.; Zheng, X.; Leopold, W.R.; Pryer, N.K.; et al. Specific Inhibition of Cyclin-Dependent Kinase 4/6 by PD 0332991 and Associated Antitumor Activity in Human Tumor Xenografts. Mol. Cancer Ther. 2004, 3, 1427-1438. [PubMed]

144. Roberts, P.J.; Bisi, J.E.; Strum, J.C.; Combest, A.J.; Darr, D.B.; Usary, J.E.; Zamboni, W.C.; Wong, K.-K.; Perou, C.M.; Sharpless, N.E Multiple Roles of Cyclin-Dependent Kinase 4/6 Inhibitors in Cancer Therapy. J. Natl. Cancer Inst. 2012, 104, 476-487. [CrossRef]

145. Flaherty, K.T.; Lorusso, P.M.; Demichele, A.; Abramson, V.G.; Courtney, R.; Randolph, S.S.; Shaik, M.N.; Wilner, K.D.; O’Dwyer, P.J.; Schwartz, G.K. Phase I, Dose-Escalation Trial of the Oral Cyclin-Dependent Kinase 4/6 Inhibitor PD 0332991, Administered Using a 21-Day Schedule in Patients with Advanced Cancer. Clin. Cancer Res. 2012, 18, 568-576. [CrossRef] [PubMed]

146. Schwartz, G.K.; LoRusso, P.M.; Dickson, M.A.; Randolph, S.S.; Shaik, M.N.; Wilner, K.D.; Courtney, R.; O’Dwyer, P.J. Phase I Study of PD 0332991, a Cyclin-Dependent Kinase Inhibitor, Administered in 3-Week Cycles (Schedule 2/1). Br. J. Cancer 2011, 104, 1862-1868. [CrossRef] [PubMed]

147. Galot, R.; Le Tourneau, C.; Guigay, J.; Licitra, L.; Tinhofer, I.; Kong, A.; Caballero, C.; Fortpied, C.; Bogaerts, J.; Govaerts, A.-S.; et al. Personalized Biomarker-Based Treatment Strategy for Patients with Squamous Cell Carcinoma of the Head and Neck: EORTC Position and Approach. Ann. Oncol. 2018, 29, 2313-2327. [CrossRef] [PubMed]

148. Tao, Y.-F.; Wang, N.-N.; Xu, L.-X.; Li, Z.-H.; Li, X.-L.; Xu, Y.-Y.; Fang, F.; Li, M.; Qian, G.-H.; Li, Y.-H.; et al. Molecular Mechanism of G1 Arrest and Cellular Senescence Induced by LEE011, a Novel CDK4/CDK6 Inhibitor, in Leukemia Cells. Cancer Cell Int. 2017, 17, 35. [CrossRef]

149. Wood, A.C.; Krytska, K.; Ryles, H.T.; Infarinato, N.R.; Sano, R.; Hansel, T.D.; Hart, L.S.; King, F.J.; Smith, T.R.; Ainscow, E.; et al. Dual ALK and CDK4/6 Inhibition Demonstrates Synergy against Neuroblastoma. Clin. Cancer Res. 2017, 23, 2856-2868. [CrossRef]

150. Aristizabal Prada, E.T.; Nölting, S.; Spoettl, G.; Maurer, J.; Auernhammer, C.J. The Novel Cyclin-Dependent Kinase $4 / 6$ Inhibitor Ribociclib (LEE011) Alone and in Dual-Targeting Approaches Demonstrates Antitumoral Efficacy in Neuroendocrine Tumors in Vitro. Neuroendocrinology 2018, 106, 58-73. [CrossRef] [PubMed]

151. Zhang, Y.-X.; Sicinska, E.; Czaplinski, J.T.; Remillard, S.P.; Moss, S.; Wang, Y.; Brain, C.; Loo, A.; Snyder, E.L.; Demetri, G.D.; et al. Antiproliferative Effects of CDK4/6 Inhibition in CDK4-Amplified Human Liposarcoma in Vitro and in Vivo. Mol. Cancer Ther. 2014, 13, 2184-2193. [CrossRef] 
152. Goel, S.; Wang, Q.; Watt, A.C.; Tolaney, S.M.; Dillon, D.A.; Li, W.; Ramm, S.; Palmer, A.C.; Yuzugullu, H.; Varadan, V.; et al. Overcoming Therapeutic Resistance in HER2-Positive Breast Cancers with CDK4/6 Inhibitors. Cancer Cell 2016, 29, 255-269. [CrossRef]

153. van Caloen, G.; Schmitz, S.; Baroudi, M.E.; Caignet, X.; Ruys, S.P.; dit Roger, P.P.; Vertommen, D.; Machiels, J.-P. Preclinical Activity of Ribociclib in Squamous Cell Carcinoma of the Head and Neck. Mol. Cancer Ther. 2020, 19, 777-789. [CrossRef] [PubMed]

154. Vora, S.R.; Juric, D.; Kim, N.; Mino-Kenudson, M.; Huynh, T.; Costa, C.; Lockerman, E.L.; Pollack, S.F.; Liu, M.; Li, X.; et al. CDK 4/6 Inhibitors Sensitize PIK3CA Mutant Breast Cancer to PI3K Inhibitors. Cancer Cell 2014, 26, 136-149. [CrossRef] [PubMed]

155. Wu, T.; Chen, Z.; To, K.K.W.; Fang, X.; Wang, F.; Cheng, B.; Fu, L. Effect of Abemaciclib (LY2835219) on Enhancement of Chemotherapeutic Agents in ABCB1 and ABCG2 Overexpressing Cells in Vitro and in Vivo. Biochem. Pharmacol. 2017, 124, 29-42. [CrossRef] [PubMed]

156. Yadav, V.; Burke, T.F.; Huber, L.; Van Horn, R.D.; Zhang, Y.; Buchanan, S.G.; Chan, E.M.; Starling, J.J.; Beckmann, R.P.; Peng, S.-B. The CDK4/ 6 Inhibitor LY2835219 Overcomes Vemurafenib Resistance Resulting from MAPK Reactivation and Cyclin D1 Upregulation. Mol. Cancer Ther. 2014, 13, 2253-2263. [CrossRef] [PubMed]

157. Sathe, A.; Koshy, N.; Schmid, S.C.; Thalgott, M.; Schwarzenböck, S.M.; Krause, B.J.; Holm, P.S.; Gschwend, J.E.; Retz, M.; Nawroth, R. CDK4/6 Inhibition Controls Proliferation of Bladder Cancer and Transcription of RB1. J. Urol. 2016, 195, 771-779. [CrossRef] [PubMed]

158. PubMed. The CDK4/6 Inhibitor LY2835219 Has Potent Activity in Combination with MTOR Inhibitor in Head and Neck Squamous Cell Carcinoma. Available online: https:/ / pubmed.ncbi.nlm.nih.gov/26909611/ (accessed on 13 October 2021).

159. Herrera-Abreu, M.T.; Palafox, M.; Asghar, U.; Rivas, M.A.; Cutts, R.J.; Garcia-Murillas, I.; Pearson, A.; Guzman, M.; Rodriguez, O.; Grueso, J.; et al. Early Adaptation and Acquired Resistance to CDK4/6 Inhibition in Estrogen Receptor-Positive Breast Cancer. Cancer Res. 2016, 76, 2301-2313. [CrossRef] [PubMed]

160. Haines, E.; Chen, T.; Kommajosyula, N.; Chen, Z.; Herter-Sprie, G.S.; Cornell, L.; Wong, K.-K.; Shapiro, G.I. Palbociclib Resistance Confers Dependence on an FGFR-MAP Kinase-MTOR-Driven Pathway in KRAS-Mutant Non-Small Cell Lung Cancer. Oncotarget 2018, 9, 31572-31589. [CrossRef]

161. Office of the Commissioner. FDA Approves Drug to Reduce Bone Marrow Suppression Caused by Chemotherapy. Available online: https: / /www.fda.gov/news-events/press-announcements/fda-approves-drug-reduce-bone-marrow-suppressioncaused-chemotherapy (accessed on 22 December 2021).

162. Wang, Y.; Zhang, T.; Kwiatkowski, N.; Abraham, B.J.; Lee, T.I.; Xie, S.; Yuzugullu, H.; Von, T.; Li, H.; Lin, Z.; et al. CDK7-Dependent Transcriptional Addiction in Triple-Negative Breast Cancer. Cell 2015, 163, 174-186. [CrossRef]

163. Dannappel, M.V.; Sooraj, D.; Loh, J.J.; Firestein, R. Molecular and in Vivo Functions of the CDK8 and CDK19 Kinase Modules. Front. Cell Dev. Biol. 2019, 6, 171. [CrossRef]

164. Shao, H.; Shi, S.; Huang, S.; Hole, A.J.; Abbas, A.Y.; Baumli, S.; Liu, X.; Lam, F.; Foley, D.W.; Fischer, P.M.; et al. Substituted 4-(Thiazol-5-Yl)-2-(Phenylamino)Pyrimidines Are Highly Active CDK9 Inhibitors: Synthesis, X-Ray Crystal Structures, StructureActivity Relationship, and Anticancer Activities. J. Med. Chem. 2013, 56, 640-659. [CrossRef]

165. Liu, X.; Shi, S.; Lam, F.; Pepper, C.; Fischer, P.M.; Wang, S. CDKI-71, a Novel CDK9 Inhibitor, Is Preferentially Cytotoxic to Cancer Cells Compared to Flavopiridol. Int. J. Cancer 2012, 130, 1216-1226. [CrossRef]

166. Walsby, E.; Pratt, G.; Shao, H.; Abbas, A.Y.; Fischer, P.M.; Bradshaw, T.D.; Brennan, P.; Fegan, C.; Wang, S.; Pepper, C. A Novel Cdk9 Inhibitor Preferentially Targets Tumor Cells and Synergizes with Fludarabine. Oncotarget 2013, 5, 375-385. [CrossRef] [PubMed]

167. Németh, G.; Greff, Z.; Sipos, A.; Varga, Z.; Székely, R.; Sebestyén, M.; Jászay, Z.; Béni, S.; Nemes, Z.; Pirat, J.L.; et al. Synthesis and Evaluation of Phosphorus Containing, Specific CDK9/CycT1 Inhibitors. J. Med. Chem. 2014, 57, 3939-3965. [CrossRef] [PubMed]

168. Cidado, J.; Boiko, S.; Proia, T.; Ferguson, D.; Criscione, S.W.; San Martin, M.; Pop-Damkov, P.; Su, N.; Roamio Franklin, V.N.; Sekhar Reddy Chilamakuri, C.; et al. AZD4573 Is a Highly Selective CDK9 Inhibitor That Suppresses MCL-1 and Induces Apoptosis in Hematologic Cancer Cells. Clin. Cancer Res. 2020, 26, 922-934. [CrossRef] [PubMed]

169. Cheng, S.-W.G.; Kuzyk, M.A.; Moradian, A.; Ichu, T.-A.; Chang, V.C.-D.; Tien, J.F.; Vollett, S.E.; Griffith, M.; Marra, M.A.; Morin, G.B. Interaction of Cyclin-Dependent Kinase 12/CrkRS with Cyclin K1 Is Required for the Phosphorylation of the C-Terminal Domain of RNA Polymerase II. Mol. Cell. Biol. 2012, 32, 4691-4704. [CrossRef]

170. Quereda, V.; Bayle, S.; Vena, F.; Frydman, S.M.; Monastyrskyi, A.; Roush, W.R.; Duckett, D.R. Therapeutic Targeting of CDK12/CDK13 in Triple-Negative Breast Cancer. Cancer Cell 2019, 36, 545-558.e7. [CrossRef] [PubMed]

171. Wang, C.; Wang, H.; Lieftink, C.; du Chatinier, A.; Gao, D.; Jin, G.; Jin, H.; Beijersbergen, R.L.; Qin, W.; Bernards, R. CDK12 Inhibition Mediates DNA Damage and Is Synergistic with Sorafenib Treatment in Hepatocellular Carcinoma. Gut 2020, 69, 727-736. [CrossRef]

172. Witkiewicz, A.K.; Knudsen, E.S. Retinoblastoma Tumor Suppressor Pathway in Breast Cancer: Prognosis, Precision Medicine, and Therapeutic Interventions. Breast Cancer Res. 2014, 16, 207. [CrossRef]

173. Dean, J.L.; McClendon, A.K.; Hickey, T.E.; Butler, L.M.; Tilley, W.D.; Witkiewicz, A.K.; Knudsen, E.S. Therapeutic Response to CDK4/6 Inhibition in Breast Cancer Defined by Ex Vivo Analyses of Human Tumors. Cell Cycle 2012, 11, 2756-2761. [CrossRef] [PubMed] 
174. Turner, N.C.; Liu, Y.; Zhu, Z.; Loi, S.; Colleoni, M.; Loibl, S.; DeMichele, A.; Harbeck, N.; André, F.; Bayar, M.A.; et al. Cyclin E1 Expression and Palbociclib Efficacy in Previously Treated Hormone Receptor-Positive Metastatic Breast Cancer. J. Clin. Oncol. 2019, 37, 1169-1178. [CrossRef]

175. Cen, L.; Carlson, B.L.; Schroeder, M.A.; Ostrem, J.L.; Kitange, G.J.; Mladek, A.C.; Fink, S.R.; Decker, P.A.; Wu, W.; Kim, J.-S.; et al. P16-Cdk4-Rb Axis Controls Sensitivity to a Cyclin-Dependent Kinase Inhibitor PD0332991 in Glioblastoma Xenograft Cells. Neuro-Oncology 2012, 14, 870-881. [CrossRef]

176. Condorelli, R.; Spring, L.; O’Shaughnessy, J.; Lacroix, L.; Bailleux, C.; Scott, V.; Dubois, J.; Nagy, R.J.; Lanman, R.B.; Iafrate, A.J.; et al. Polyclonal RB1 Mutations and Acquired Resistance to CDK 4/6 Inhibitors in Patients with Metastatic Breast Cancer. Ann. Oncol. 2018, 29, 640-645. [CrossRef]

177. Li, Z.; Razavi, P.; Li, Q.; Toy, W.; Liu, B.; Ping, C.; Hsieh, W.; Sanchez-Vega, F.; Brown, D.N.; Da Cruz Paula, A.F.; et al. Loss of the FAT1 Tumor Suppressor Promotes Resistance to CDK4/6 Inhibitors via the Hippo Pathway. Cancer Cell 2018, 34, 893-905.e8. [CrossRef] [PubMed]

178. Alessi, D.R.; James, S.R.; Downes, C.P.; Holmes, A.B.; Gaffney, P.R.J.; Reese, C.B.; Cohen, P. Characterization of a 3Phosphoinositide-Dependent Protein Kinase which Phosphorylates and Activates Protein Kinase B $\alpha$. Curr. Biol. 1997, 7, $261-269$. [CrossRef]

179. Jansen, V.M.; Bhola, N.E.; Bauer, J.A.; Formisano, L.; Lee, K.-M.; Hutchinson, K.E.; Witkiewicz, A.K.; Moore, P.D.; Estrada, M.V.; Sánchez, V.; et al. Kinome-Wide RNA Interference Screen Reveals a Role for PDK1 in Acquired Resistance to CDK4/6 Inhibition in ER-Positive Breast Cancer. Cancer Res. 2017, 77, 2488-2499. [CrossRef] [PubMed]

180. Novotný, J.; Bandúrová, V.; Strnad, H.; Chovanec, M.; Hradilová, M.; Šáchová, J.; Šteffl, M.; Grušanović, J.; Kodet, R.; Pačes, V.; et al. Analysis of HPV-Positive and HPV-Negative Head and Neck Squamous Cell Carcinomas and Paired Normal Mucosae Reveals Cyclin D1 Deregulation and Compensatory Effect of Cyclin D2. Cancers 2020, 12, 792. [CrossRef]

181. Lawrence, M.S.; Sougnez, C.; Lichtenstein, L.; Cibulskis, K.; Lander, E.; Gabriel, S.B.; Getz, G.; Ally, A.; Balasundaram, M.; Birol, I.; et al. Comprehensive Genomic Characterization of Head and Neck Squamous Cell Carcinomas. Nature 2015, 517, 576-582. [CrossRef]

182. Chen, W.S.; Bindra, R.S.; Mo, A.; Hayman, T.; Husain, Z.; Contessa, J.N.; Gaffney, S.G.; Townsend, J.P.; Yu, J.B. CDKN2A Copy Number Loss Is an Independent Prognostic Factor in HPV-Negative Head and Neck Squamous Cell Carcinoma. Front. Oncol. 2018, 8, 95. [CrossRef]

183. Feng, Z.; Guo, W.; Zhang, C.; Xu, Q.; Zhang, P.; Sun, J.; Zhu, H.; Wang, Z.; Li, J.; Wang, L.; et al. CCND1 as a Predictive Biomarker of Neoadjuvant Chemotherapy in Patients with Locally Advanced Head and Neck Squamous Cell Carcinoma. PLoS ONE 2011, 6, e26399. [CrossRef]

184. Ang, K.K.; Harris, J.; Wheeler, R.; Weber, R.; Rosenthal, D.I.; Nguyen-Tân, P.F.; Westra, W.H.; Chung, C.H.; Jordan, R.C.; Lu, C.; et al. Human Papillomavirus and Survival of Patients with Oropharyngeal Cancer. N. Engl. J. Med. 2010, 363, 24-35. [CrossRef]

185. Wiest, T.; Schwarz, E.; Enders, C.; Flechtenmacher, C.; Bosch, F.X. Involvement of Intact HPV16 E6/E7 Gene Expression in Head and Neck Cancers with Unaltered P53 Status and Perturbed PRb Cell Cycle Control. Oncogene 2002, 21, 1510-1517. [CrossRef]

186. Chaudhary, S.; Pothuraju, R.; Rachagani, S.; Siddiqui, J.A.; Atri, P.; Mallya, K.; Nasser, M.W.; Sayed, Z.; Lyden, E.R.; Smith, L.; et al. Dual Blockade of EGFR and CDK4/6 Delays Head and Neck Squamous Cell Carcinoma Progression by Inducing Metabolic Rewiring. Cancer Lett. 2021, 510, 79-92. [CrossRef]

187. Raju, U.; Nakata, E.; Mason, K.A.; Ang, K.K.; Milas, L. Flavopiridol, a Cyclin-Dependent Kinase Inhibitor, Enhances Radiosensitivity of Ovarian Carcinoma Cells. Cancer Res. 2003, 63, 3263-3267. [PubMed]

188. Raju, U.; Ariga, H.; Koto, M.; Lu, X.; Pickett, J.; Valdecanas, D.; Mason, K.A.; Milas, L. Improvement of Esophageal Adenocarcinoma Cell and Xenograft Responses to Radiation by Targeting Cyclin-Dependent Kinases. Radiother. Oncol. 2006, 80, 185-191. [CrossRef] [PubMed]

189. Camphausen, K.; Brady, K.J.; Burgan, W.E.; Cerra, M.A.; Russell, J.S.; Bull, E.E.A.; Tofilon, P.J. Flavopiridol Enhances Human Tumor Cell Radiosensitivity and Prolongs Expression of GammaH2AX Foci. Mol. Cancer Ther. 2004, 3, 409-416. [PubMed]

190. Göttgens, E.-L.; Bussink, J.; Leszczynska, K.B.; Peters, H.; Span, P.N.; Hammond, E.M. Inhibition of CDK4/CDK6 Enhances Radiosensitivity of HPV Negative Head and Neck Squamous Cell Carcinomas. Int. J. Radiat. Oncol. Biol. Phys. 2019, 105, 548-558. [CrossRef]

191. Tao, Z.; Le Blanc, J.M.; Wang, C.; Zhan, T.; Zhuang, H.; Wang, P.; Yuan, Z.; Lu, B. Coadministration of Trametinib and Palbociclib Radiosensitizes KRAS-Mutant Non-Small Cell Lung Cancers In Vitro and In Vivo. Clin. Cancer Res. 2016, 22, 122-133. [CrossRef] [PubMed]

192. Tai, T.-S.; Lin, P.-M.; Wu, C.-F.; Hung, S.-K.; Huang, C.-I.; Wang, C.-C.; Su, Y.-C. CDK4/6 Inhibitor LEE011 Is a Potential Radiation-Sensitizer in Head and Neck Squamous Cell Carcinoma: An In Vitro Study. Anticancer Res. 2019, 39, 713-720. [CrossRef]

193. Jung, S.-Y.; Nam, K.-Y.; Park, J.-I.; Song, K.-H.; Ahn, J.; Park, J.K.; Um, H.-D.; Hwang, S.-G.; Choi, S.U.; Song, J.-Y. Radiosensitizing Effect of Novel Phenylpyrimidine Derivatives on Human Lung Cancer Cells via Cell Cycle Perturbation. J. Pharmacol. Exp. Ther. 2019, 370, 514-527. [CrossRef]

194. Kodym, E.; Kodym, R.; Reis, A.E.; Habib, A.A.; Story, M.D.; Saha, D. The Small-Molecule CDK Inhibitor, SNS-032, Enhances Cellular Radiosensitivity in Quiescent and Hypoxic Non-Small Cell Lung Cancer Cells. Lung Cancer 2009, 66, 37-47. [CrossRef] [PubMed] 
195. Raghavan, P.; Tumati, V.; Yu, L.; Chan, N.; Tomimatsu, N.; Burma, S.; Bristow, R.G.; Saha, D. AZD5438, an Inhibitor of Cdk1, 2, and 9, Enhances the Radiosensitivity of Non-Small Cell Lung Carcinoma Cells. Int. J. Radiat. Oncol. Biol. Phys. 2012, 84, e507-e514. [CrossRef] [PubMed]

196. Storch, K.; Cordes, N. The Impact of CDK9 on Radiosensitivity, DNA Damage Repair and Cell Cycling of HNSCC Cancer Cells. Int. J. Oncol. 2016, 48, 191-198. [CrossRef]

197. Lee, M.S.; Helms, T.L.; Feng, N.; Gay, J.; Chang, Q.E.; Tian, F.; Wu, J.Y.; Toniatti, C.; Heffernan, T.P.; Powis, G.; et al. Efficacy of the Combination of MEK and CDK4/6 Inhibitors in Vitro and in Vivo in KRAS Mutant Colorectal Cancer Models. Oncotarget 2016, 7, 39595-39608. [CrossRef]

198. Liu, M.; Xu, S.; Wang, Y.; Li, Y.; Li, Y.; Zhang, H.; Liu, H.; Chen, J. PD 0332991, a Selective Cyclin D Kinase $4 / 6$ Inhibitor Sensitizes Lung Cancer Cells to Treatment with Epidermal Growth Factor Receptor Tyrosine Kinase Inhibitors. Oncotarget 2016, 7, 84951-84964. [CrossRef] [PubMed]

199. Cretella, D.; Ravelli, A.; Fumarola, C.; La Monica, S.; Digiacomo, G.; Cavazzoni, A.; Alfieri, R.; Biondi, A.; Generali, D.; Bonelli, M.; et al. The Anti-Tumor Efficacy of CDK4/6 Inhibition Is Enhanced by the Combination with PI3K/AKT/MTOR Inhibitors through Impairment of Glucose Metabolism in TNBC Cells. J. Exp. Clin. Cancer Res. CR 2018, 37, 72. [CrossRef] [PubMed]

200. Zhang, J.; Zhou, L.; Zhao, S.; Dicker, D.T.; El-Deiry, W.S. The CDK4/ 6 Inhibitor Palbociclib Synergizes with Irinotecan to Promote Colorectal Cancer Cell Death under Hypoxia. Cell Cycle 2017, 16, 1193-1200. [CrossRef] [PubMed]

201. Ziemke, E.K.; Dosch, J.S.; Maust, J.D.; Shettigar, A.; Sen, A.; Welling, T.H.; Hardiman, K.M.; Sebolt-Leopold, J.S. Sensitivity of KRAS-Mutant Colorectal Cancers to Combination Therapy That Cotargets MEK and CDK4/6. Clin. Cancer Res. 2016, 22, 405-414. [CrossRef]

202. Yoshida, A.; Lee, E.K.; Diehl, J.A. Induction of Therapeutic Senescence in Vemurafenib-Resistant Melanoma by Extended Inhibition of CDK4/6. Cancer Res. 2016, 76, 2990-3002. [CrossRef]

203. Louveau, B.; Resche-Rigon, M.; Lesimple, T.; Meda, L.D.; Pracht, M.; Baroudjian, B.; Delyon, J.; Amini-Adle, M.; Dutriaux, C.; de Moura, C.R.; et al. Phase I-II Open-Label Multicenter Study of Palbociclib + Vemurafenib in BRAFV600MUT Metastatic Melanoma Patients: Uncovering CHEK2 as a Major Response Mechanism. Clin. Cancer Res. 2021, 27, 3876-3883. [CrossRef] [PubMed]

204. Adkins, D.; Ley, J.; Neupane, P.; Worden, F.; Sacco, A.G.; Palka, K.; Grilley-Olson, J.E.; Maggiore, R.; Salama, N.N.; Trinkaus, K.; et al. Palbociclib and Cetuximab in Platinum-Resistant and in Cetuximab-Resistant Human Papillomavirus-Unrelated Head and Neck Cancer: A Multicentre, Multigroup, Phase 2 Trial. Lancet Oncol. 2019, 20, 1295-1305. [CrossRef]

205. Adkins, D.; Lin, J.-C.; Sacco, A.G.; Ley, J.C.; Oppelt, P.; Shen, Q.; Kern, K.A.; Thurm, H.C.; Wang, S.-L.; Martini, J.-F.; et al. Palbociclib plus Cetuximab versus Placebo plus Cetuximab in Platinum-Resistant, Cetuximab-Naive, HPV-Unrelated Head and Neck Cancer: A Double-Blind Randomized Phase II Trial (PALATINUS). J. Clin. Oncol. 2019, 37, 6013. [CrossRef]

206. Robinson, A.M.; Rathore, R.; Redlich, N.J.; Adkins, D.R.; Van Arsdale, T.; Van Tine, B.A.; Michel, L.S. Cisplatin Exposure Causes C-Myc-Dependent Resistance to CDK4/6 Inhibition in HPV-Negative Head and Neck Squamous Cell Carcinoma. Cell Death Dis. 2019, 10, 867. [CrossRef] [PubMed]

207. Beck, T.N.; Georgopoulos, R.; Shagisultanova, E.I.; Sarcu, D.; Handorf, E.A.; Dubyk, C.; Lango, M.N.; Ridge, J.A.; Astsaturov, I.; Serebriiskii, I.G.; et al. EGFR and RB1 as Dual Biomarkers in HPV-Negative Head and Neck Cancer. Mol. Cancer Ther. 2016, 15, 2486-2497. [CrossRef]

208. Gadsden, N.J.; Fulcher, C.D.; Li, D.; Shrivastava, N.; Thomas, C.; Segall, J.E.; Prystowsky, M.B.; Schlecht, N.F.; Gavathiotis, E.; Ow, T.J. Palbociclib Renders Human Papilloma Virus-Negative Head and Neck Squamous Cell Carcinoma Vulnerable to the Senolytic Agent Navitoclax. Mol. Cancer Res. MCR 2021, 19, 862-873. [CrossRef]

209. Fang, Z.; Jung, K.H.; Lee, J.E.; Cho, J.; Lim, J.H.; Hong, S.-S. MEK Blockade Overcomes the Limited Activity of Palbociclib in Head and Neck Cancer. Transl. Oncol. 2020, 13, 100833. [CrossRef]

210. Zainal, N.S.; Lee, B.K.B.; Wong, Z.W.; Chin, I.S.; Yee, P.S.; Gan, C.P.; Mun, K.S.; Rahman, Z.A.A.; Gutkind, J.S.; Patel, V.; et al Effects of Palbociclib on Oral Squamous Cell Carcinoma and the Role of PIK3CA in Conferring Resistance. Cancer Biol. Med. 2019, 16, 264-275. [CrossRef] [PubMed]

211. Lashinger, L.M.; Zhu, K.; Williams, S.A.; Shrader, M.; Dinney, C.P.N.; McConkey, D.J. Bortezomib Abolishes Tumor Necrosis Factor-Related Apoptosis-Inducing Ligand Resistance via a P21-Dependent Mechanism in Human Bladder and Prostate Cancer Cells. Cancer Res. 2005, 65, 4902-4908. [CrossRef]

212. Chen, S.; Dai, Y.; Pei, X.-Y.; Myers, J.; Wang, L.; Kramer, L.B.; Garnett, M.; Schwartz, D.M.; Su, F.; Simmons, G.L.; et al. CDK Inhibitors Upregulate BH3-Only Proteins to Sensitize Human Myeloma Cells to BH3 Mimetic Therapies. Cancer Res. 2012, 72, 4225-4237. [CrossRef]

213. Kelly, G.L.; Strasser, A. Toward Targeting Antiapoptotic MCL-1 for Cancer Therapy. Annu. Rev. Cancer Biol. 2020, 4, 299-313. [CrossRef]

214. Cao, S.; Yu, Y.; Chen, S.; Lei, D.; Wang, S.; Pan, X.; Peng, J. Inhibition of CDK9 Induces Apoptosis and Potentiates the Effect of Cisplatin in Hypopharyngeal Carcinoma Cells. Biochem. Biophys. Res. Commun. 2017, 482, 536-541. [CrossRef]

215. Syn, N.L.; Lim, P.L.; Kong, L.R.; Wang, L.; Wong, A.L.-A.; Lim, C.M.; Loh, T.K.S.; Siemeister, G.; Goh, B.C.; Hsieh, W.-S. Pan-CDK Inhibition Augments Cisplatin Lethality in Nasopharyngeal Carcinoma Cell Lines and Xenograft Models. Signal Transduct. Target. Ther. 2018, 3, 9. [CrossRef] 
216. Swiecicki, P.L.; Durm, G.; Bellile, E.; Bhangale, A.; Brenner, J.C.; Worden, F.P. A Multi-Center Phase II Trial Evaluating the Efficacy of Palbociclib in Combination with Carboplatin for the Treatment of Unresectable Recurrent or Metastatic Head and Neck Squamous Cell Carcinoma. Investig. New Drugs 2020, 38, 1550-1558. [CrossRef]

217. Salvador-Barbero, B.; Alvarez-Fernández, M.; Zapatero-Solana, E.; El Bakkali, A.; Menéndez, M.d.C.; López-Casas, P.P.; Di Domenico, T.; Xie, T.; VanArsdale, T.; Shields, D.J.; et al. CDK4/6 Inhibitors Impair Recovery from Cytotoxic Chemotherapy in Pancreatic Adenocarcinoma. Cancer Cell 2020, 38, 584. [CrossRef]

218. Zhang, J.; Bu, X.; Wang, H.; Zhu, Y.; Geng, Y.; Nihira, N.T.; Tan, Y.; Ci, Y.; Wu, F.; Dai, X.; et al. Cyclin D-CDK4 Kinase Destabilizes PD-L1 via Cullin 3-SPOP to Control Cancer Immune Surveillance. Nature 2018, 553, 91-95. [CrossRef] [PubMed]

219. Ferris, R.L.; Blumenschein, G.; Fayette, J.; Guigay, J.; Colevas, A.D.; Licitra, L.; Harrington, K.; Kasper, S.; Vokes, E.E.; Even, C.; et al. Nivolumab for Recurrent Squamous-Cell Carcinoma of the Head and Neck. N. Engl. J. Med. 2016, 375, 1856-1867. [CrossRef] [PubMed]

220. Keir, M.E.; Butte, M.J.; Freeman, G.J.; Sharpe, A.H. PD-1 and Its Ligands in Tolerance and Immunity. Anmu. Rev. Immunol. 2008, 26, 677-704. [CrossRef]

221. Seiwert, T.Y.; Burtness, B.; Mehra, R.; Weiss, J.; Berger, R.; Eder, J.P.; Heath, K.; McClanahan, T.; Lunceford, J.; Gause, C.; et al. Safety and Clinical Activity of Pembrolizumab for Treatment of Recurrent or Metastatic Squamous Cell Carcinoma of the Head and Neck (KEYNOTE-012): An Open-Label, Multicentre, Phase 1b Trial. Lancet Oncol. 2016, 17, 956-965. [CrossRef]

222. Riess, C.; Irmscher, N.; Salewski, I.; Strüder, D.; Classen, C.-F.; Große-Thie, C.; Junghanss, C.; Maletzki, C. Cyclin-Dependent Kinase Inhibitors in Head and Neck Cancer and Glioblastoma-Backbone or Add-on in Immune-Oncology? Cancer Metastasis Rev. 2021, 40, 153-171. [CrossRef] 